\title{
Erratum to: New insights into Lithocodium aggregatum Elliott 1956 and Bacinella irregularis Radoičić 1959 (Late Jurassic-Lower Cretaceous): two ulvophycean green algae (?Order Ulotrichales) with a heteromorphic life cycle (epilithic/euendolithic)
}

\author{
Felix Schlagintweit $\cdot$ Telm Bover-Arnal $\cdot$ Ramon Salas
}

Published online: 11 May 2010

(C) Springer-Verlag 2010

\begin{abstract}
The Late Jurassic-Lower Cretaceous microorganisms incertae sedis Lithocodium aggregatum Elliott and Bacinella irregularis Radoičić are taxonomically studied based on material from the Lower Aptian of the western Maestrat Basin (Spain). This study is supplemented with detailed photographs from Elliot's type-material. Given that the original description of Lithocodium aggregatum is ambiguous, a detail from the holotype is chosen as an epitype to serve as an interpretative type (article 9.7 ICBN). Lithocodium is re-interpreted as a filamentousseptate heterotrichale ulvophycean alga (?order Ulotrichales) exhibiting a heteromorphic life cycle consisting of two phases: an epilithic gametophytic and a euendolithic
\end{abstract}

The online version of the original article can be found under doi: 10.1007/s10347-010-0222-4.

Owing to technical problems, the majority of the author's extensive proof corrections were not received. The fully corrected version is given now.

F. Schlagintweit $(\square)$

Lerchenauerstr. 167, 80935 Munich, Germany

e-mail: ef.schlagintweit@t-online.de

T. Bover-Arnal

Abteilung Geologie, Fakultät für Biologie,

Chemie und Geowissenschaften, Universität Bayreuth,

Universitätsstr. 30, 95440 Bayreuth, Germany

e-mail: Telm.Bover@uni-bayreuth.de

R. Salas

Departament de Geoquímica,

Petrologia i Prospecció Geològica,

Facultat de Geologia, Universitat de Barcelona,

Martí i Franqués s/n, 08028 Barcelona, Spain

e-mail: ramonsalas@ub.edu sporophytic (Gomontia stage). Bacinella irregularis is interpreted and redescribed as a purely euendolithic ulvophycean alga which bores into either Lithocodium aggregatum or the substrate below Lithocodium crusts. A small microendolith boring into Lithocodium crusts capable of cryptobiotically stretching within its filamentous network is tentatively assigned to the siphonal chlorophyte Ostreobium Bornet and Flahault. Another associated microfilamentous boring chlorophyte with characteristic long thin hairs (setae) is described as Phaeophila? sp. The euendolithic community comprises a variety of micro- and macroborings that affect the thalli of Lithocodium. Finally, the filaments of the outer zone of the Lithocodium crust are infested by calcimicrobes (cyanobacteria, ?fungi). The description made by Elliott in his original work of the "inner layer" of Lithocodium aggregatum as "confused" is explained here as a complex multitaxon chlorophyte-calcimicrobial assemblage overprinted by multiple bioerosion ichnofabrics.

Keywords Genus Lithocodium - Genus Bacinella . Chlorophyceae · Ichnotaxa $\cdot$ Calcimicrobes $\cdot$ Bioerosion . Systematics $\cdot$ Late Jurassic $\cdot$ Early Cretaceous

\section{Introduction}

Microproblematica are microfossils with an unknown or uncertain systematic position, which were especially widespread within Upper Triassic-Cretaceous Tethyan platform carbonates (e.g., Senowbari-Daryan 1980, 1984; Schlagintweit 1991; Schmid 1996). Of all these enigmatic taxa, two of the best known are Lithocodium aggregatum Elliott (1956) and Bacinella irregularis Radoičić (1959). The taxonomic 
nature of these two microproblematica, as well as their possible relationship or synonymies, has been the subject of much controversy over the last 50 years. Lithocodium aggregatum was originally described as a siphonal (= nonseptate filaments) codiacean alga from the Lower Cretaceous subsurface (most probably Hauterivian according to Banner et al. 1990, p. 30; see also Ziegler 2001) from the Rumaila oil field near Basra, Iraq. Its codiacean nature was accepted by many subsequent authors (e.g., Johnson 1964; Poignant 1968; Höfling 1985; Banner et al. 1990; Radoičić 2005). Segonzac and Marin (1972) analyzed material with Lithocodium aggregatum from the Lower Aptian of Spain, including one locality (Barranco de Los Degollados) sampled in the present study (Fig. 1) and provided further details on its microstructure. They described two different types of thallial filaments: septate (with cross-partitions) basal ones and superimposed series of filaments lacking such cross-partitions. The former were compared to those present in ulochtrichalean green algae, for example genus Gomontia (op. cit., p. 333), whereas the non-septate filaments were compared to the filaments (or siphons) present in udoteacean/halimedacean green algae. Still maintaining the algal interpretation, Segonzac and Marin (1972) concluded that this obviously aberrant structure could not be related to any known taxonomic group, neither fossil nor extant, and that therefore one may consider creating a new family (op. cit., p. 334, "qu'on puisse faire un rapprochement sûr ou créer une nouvelle famille"). Some years later, Elliott (1978, p. 438) still regarded Lithocodium-Bacinella " a very doubtful structure not resolved by the re-study of Segonzac and Marin (1972)". Nearly two decades later, Banner et al. (1990) took up the idea of Segonzac and Marin (1972) and created the Lithocodoidea as a new subfamily within the Codiaceae (=Udoteaceae) including Lithocodium aggregatum. Although udoteacean green algae are siphonous, they redescribed the genus as possessing irregular septate subdermal (=medullar) filaments. Besides the assumed green algal nature, other authors proposed a sponge (Koch et al. 2002) or red alga origin (Wood 1999, p. 102), interpreted it as a lituolid foraminifera (Schmid and Leinfelder 1996) or assumed a microbial (= cyanobacterian) origin. This last view has experienced a wider acceptance, especially in recent times (e.g., Riding 1991a; Cherchi and Schroeder 2006; Conrad and Clavel
Fig. 1 Geological map of the western Maestrat Basin. The areas studied are marked with a star. Modified after Canérot et al. (1979) and Gautier (1980). The outcrop sections sampled are the following (abbreviations of thin-section samples in brackets): Barranco de los Degollados $(D E)$, Casa Cartujo (CC), Loma del Horcajo $(P O)$, Las Cubetas $(C U B)$, Cabezo de las Hoyas $(H O)$, Camarillas $(C A)$, Casa Cartujo (CC), Barranco de las Calzadas $(C A L)$ and Barranco de la Serna $(S E)$

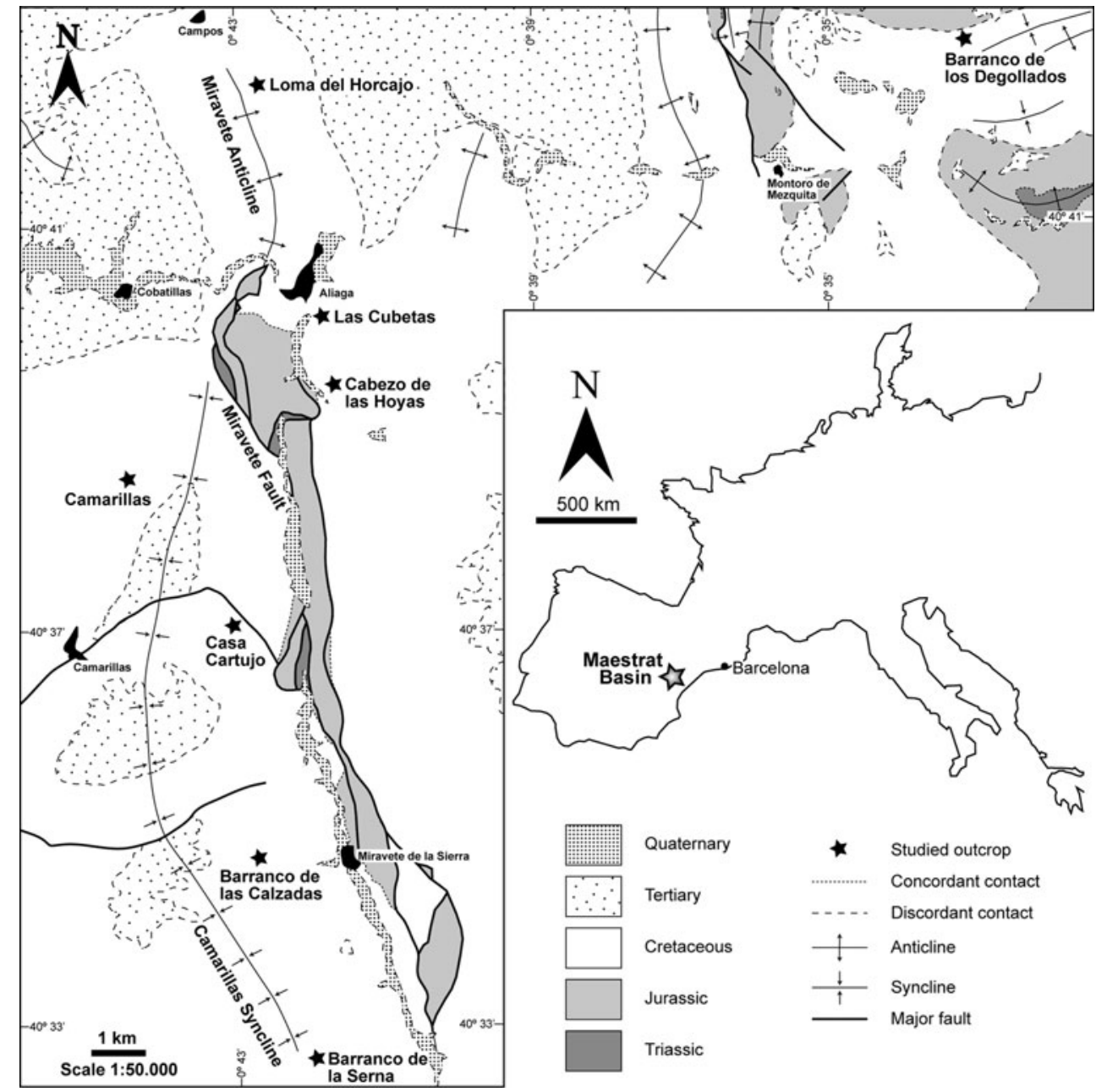


Table 1 Comparison of different taxonomic interpretations (most important views) of Lithocodium aggregatum Elliott and Bacinella irregularis Radoičić

\begin{tabular}{|c|c|c|c|c|}
\hline \multicolumn{3}{|l|}{ Lithocodium aggregatum Elliott } & \multicolumn{2}{|l|}{ Bacinella irregularis Radoičić } \\
\hline Author & Micritic crust & Internal structures & Author & Interpretation \\
\hline \multirow[t]{2}{*}{ Elliott (1956) } & \multicolumn{2}{|c|}{ Codiacean green alga } & Radoičić (1959) & Alga incertae sedis \\
\hline & \multirow[t]{2}{*}{ Thallus } & $\begin{array}{l}\text { Non-septate medullary + } \\
\text { cortical filaments }\end{array}$ & & \\
\hline $\begin{array}{l}\text { Segonzac and Marin (1972), } \\
\text { Banner et al. (1990) }\end{array}$ & & $\begin{array}{l}\text { Septate medullary }+ \\
\text { non-septate cortical } \\
\text { filaments }\end{array}$ & $\begin{array}{l}\text { Turnsek and } \\
\text { Buser (1966), } \\
\text { Beckmann and } \\
\text { Beckmann (1966) }\end{array}$ & Hydrozoa \\
\hline $\begin{array}{l}\text { Leinfelder (1986), } \\
\text { Koch et al. (2002) }\end{array}$ & \multicolumn{2}{|c|}{ Possible sponge nature } & $\begin{array}{l}\text { Segonzac and Marin (1972), } \\
\text { Luperto Sinni (1979) }\end{array}$ & $\begin{array}{l}\text { Older growth } \\
\text { stage of Lithocodium }\end{array}$ \\
\hline \multirow[t]{2}{*}{ Schmid and Leinfelder (1996) } & \multicolumn{2}{|c|}{ Lituolid foraminifera } & Banner et al. (1990) & Codiacean green \\
\hline & Test & Alveolar layer + chambers & & $\begin{array}{l}\text { alga (assuming its } \\
\text { synonymy with } \\
\text { Lithocodium) }\end{array}$ \\
\hline \multirow{2}{*}{$\begin{array}{l}\text { Riding (1991), } \\
\text { Cherchi and Schroeder (2006), } \\
\text { Conrad and Clavel (2008) }\end{array}$} & \multicolumn{2}{|c|}{ Calcimicrobial colony (= Cynobacteria) } & Schäfer and & Cynobacterian \\
\hline & Colony & Alveolar layer + cavities & $\begin{array}{l}\text { Senowbari-Daryan (1983), } \\
\text { Maurin et al. (1985), } \\
\text { Camoin and Maurin (1988), } \\
\text { Riding (1991), Schmid (1996), } \\
\text { Vachard et al. (2001), } \\
\text { Uta and Bucur (2003) }\end{array}$ & microbe \\
\hline \multirow[t]{2}{*}{ This work } & \multicolumn{2}{|c|}{ Ulotrichalean green alga } & This work & Euendolithic \\
\hline & Thallus & $\begin{array}{l}\text { Prostrate septate }+ \text { erect } \\
\text { septate filaments }\end{array}$ & & $\begin{array}{l}\text { ulotrichalean } \\
\text { green alga }\end{array}$ \\
\hline
\end{tabular}

2008). The possible foraminiferan nature of Lithocodium aggregatum proposed by Schmid and Leinfelder (1996) was discussed and rejected by Schlagintweit et al. (2005), Cherchi and Schroeder (2006) and Schlagintweit (2008). Nonetheless, other authors accepted the interpretation of Schmid and Leinfelder (e.g., Kolodzjei 1997; Dupraz and Strasser 2002; Flügel 2004; Helm 2005). In the two paleobiological online databases (www.data.gbif.org, www.paleodb. org), Lithocodium is treated as a genus within the phylum Cyanobacteria. Table 1 shows an overview of the main taxonomic positions given to Lithocodium aggregatum Elliott and the new interpretation presented in this paper.

The taxonomy of Bacinella irregularis is not so controversial as many authors assume a cyanobacterian/microbial origin (Schäfer and Senowbari-Daryan 1983; Maurin et al. 1985; Camoin and Maurin 1988; Riding 1991a; Schmid and Leinfelder 1996; Vachard et al. 2001). Vachard et al. (2001) treated Bacinella as a cyanobacterian genus of the family Aphralysiaceae. One example of a completely different interpretation is that of Turnsek and Buser (1966, p. 545) who assumed Bacinella to be a stromatoporoid: "So far we do not know any alga with similar structure. The tubes at solenopors are parallel. We consider, that Bacinella belongs to the special group of hydrozoans, like Cladocoropsis. Different forms of “cells" with partings in Bacinella remind us of coenosteal tubes and interspaces with tabulae in hydrozoans. Also the microstructure of skeletal elements of Bacinella we can obviously notice the medial dark line with radial fibrous". Elliott (1963, p. 294) recognized Bacinella as an inner structure of some Lithocodium specimens, maintaining both as "doubtfully algal growth". Elliott (1963, p. 295) also remarked that Lithocodium and Bacinella "may be constructed by the same organism". Some authors were not as cautious as Elliott and directly assumed the synonymy between Bacinella irregularis and Lithocodium aggregatum with Lithocodium having priority as described earlier (e.g., Banner et al. 1990; Koch et al. 2002). Segonzac and Marin (1972), followed by several others (e.g., Luperto Sinni 1979) regarded Bacinella as corresponding to the basal part of Lithocodium while others treated the two as different taxa (e.g., Elliott 1963, Schmid and Leinfelder 1996; Cherchi and Schroeder 2006). A completely different conclusion was drawn by Fenninger (1972), who remarked that the description of Bacinella was more complete as it referred to a subdermal structure reminiscent of Lithocodium. Furthermore, Fenninger (1972) concluded that Lithocodium could represent the incomplete stage of Bacinella, referring only to its subdermal part. In this case, the morphogenus Bacinella should have priority.

In the framework of micropaleontological studies of Lower Aptian carbonates of the western Maestrat Basin (E Iberian Chain, Spain), abundant and well-preserved 
material of Lithocodium aggregatum Elliott (1956) was analyzed. Together with detailed illustrations of Elliott's original material, it yielded new insights into its biogenic nature and morphological interpretation, allowing for an emended diagnosis.

\section{Study area and geological overview}

The specimens studied come from the Lower Aptian sedimentary succession cropping out in the western Maestrat Basin, in the eastern Iberian Chain (Fig. 1). This sedimen- tary record can be divided into two long-term transgressiveregressive sequences (Bover-Arnal et al. 2010), which comprise four lithostratigraphic formations: Morella, Xert, Forcall, and Villarroya de los Pinares (Canérot et al. 1982; Salas et al. 2001; Bover-Arnal et al. 2009a, 2010). The deposits studied lie within the marls of the Forcall Formation and constitute a sub-basin-wide horizon formed by several episodes of coral rubble encrusted by microorganisms (Fig. 2), clearly dominated by "Lithocodium-Bacinella-crusts" (Bover-Arnal 2010; Bover-Arnal et al. 2010). The taxa that compose the micropaleontological association and their relative abundances are summarized in Table 2.
Fig. 2 a Field view of the Barranco de las Calzadas area with the situation of the encrusted horizon with Lithocodium aggregatum Elliott within the marls of the Forcall Formation. b Outcrop view of the encrusted deposits with Lithocodium aggregatum Elliott exposed in the Barranco de las Calzadas section. c Schematic log of the Barranco de las Calzadas section with the situation of the rocks studied with Lithocodium aggregatum Elliott (modified from Bover-Arnal 2010)
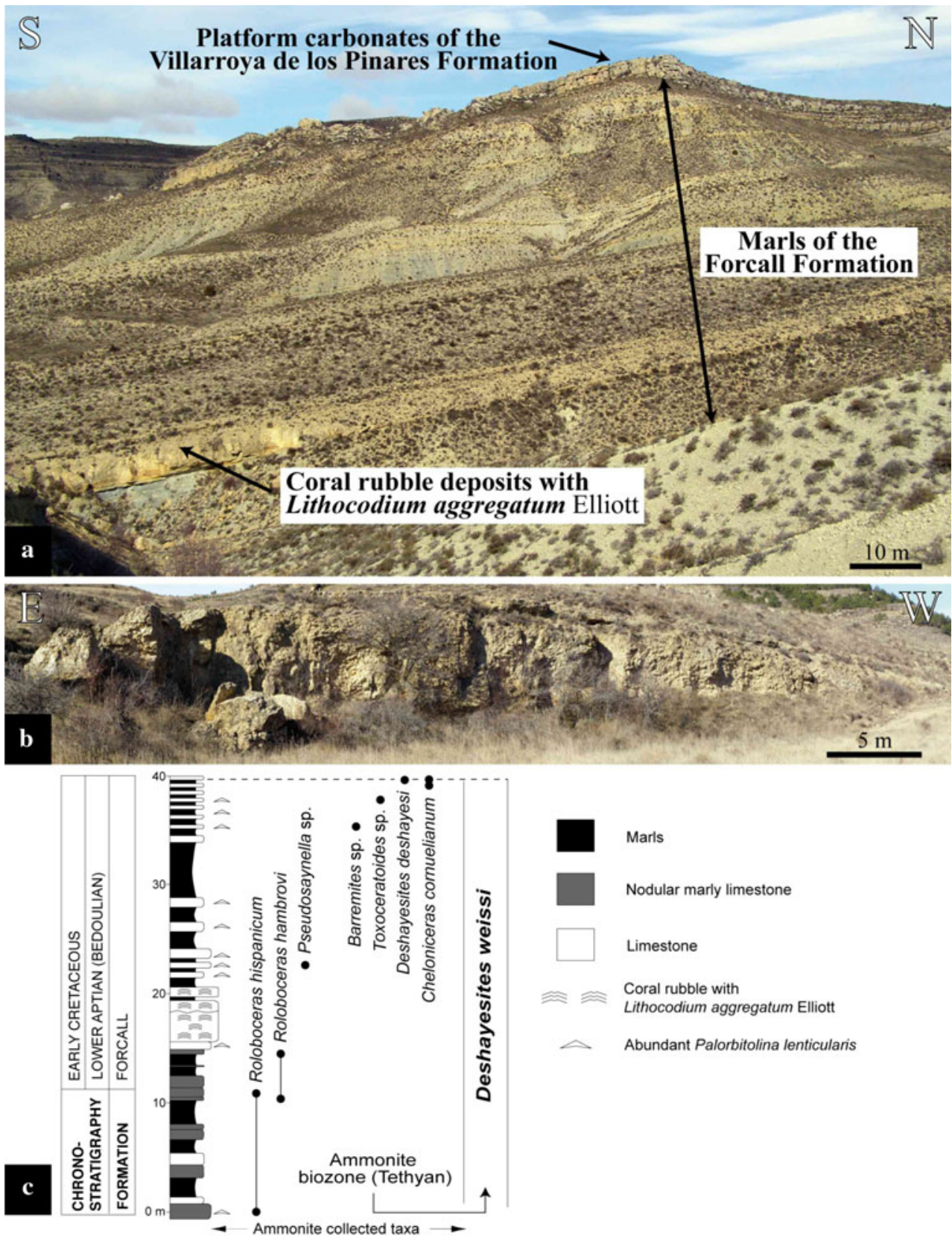
Table 2 Microfossil inventory of the encrusted deposits of the western Maestrat Basin with relative abundances

\begin{tabular}{|c|c|}
\hline Species & $\begin{array}{l}\text { Semiquantitative } \\
\text { abundance }\end{array}$ \\
\hline \multicolumn{2}{|l|}{ Benthic foraminifera } \\
\hline Bdelloidina? urgonensis Wernli and Schulte & $* * *$ \\
\hline Charentia cuvillieri Neumann & $*$ \\
\hline Choffatella cf. decipiens Schlumberger & $* * *$ \\
\hline Daxia minima Laug and Peybernes & $* * *$ \\
\hline Everticyclammina sp. & $* *$ \\
\hline Lenticulinids & $* * *$ \\
\hline $\begin{array}{l}\text { Meandrospira cf. washitensis } \\
\text { Loeblich and Tappan }\end{array}$ & $* *$ \\
\hline $\begin{array}{l}\text { Palorbitolina lenticularis } \\
\text { (Blumenbach) }\end{array}$ & $* * * *$ \\
\hline $\begin{array}{l}\text { Praeorbitolina gr. } \\
\text { cormyi-wienandsi Schroeder }\end{array}$ & $* *$ \\
\hline Textulariids & $* * * *$ \\
\hline Troglotella incrustans Wernli and Fookes & $*$ \\
\hline Neotrocholina cf. aptiensis Iocheva & $* * *$ \\
\hline Pseudoostracods sensu Samuel et al. (1972) & $* *$ \\
\hline \multicolumn{2}{|l|}{ Calcareous algae } \\
\hline Bacinella irregularis Radoičić & $* * *$ \\
\hline Lithocodium aggregatum Elliott & $* * * *$ \\
\hline Neomeris? sp. & $*$ \\
\hline Terquemella sp. & $* *$ \\
\hline Permocalculus? sp. & $* *$ \\
\hline Polystrata alba (Pfender) & $* *$ \\
\hline \multicolumn{2}{|l|}{ Incertae sedis } \\
\hline $\begin{array}{c}\text { Koskinobullina socialis } \\
\text { Cherchi and Schroeder }\end{array}$ & $* *$ \\
\hline \multicolumn{2}{|l|}{ Others } \\
\hline $\begin{array}{l}\text { Carpathocancer triangulatus } \\
\text { (Misik et al.) }\end{array}$ & $* *$ \\
\hline "Berenicea"-type bryozoa & $* *$ \\
\hline Calcistella? sp. & $*$ \\
\hline Echinoid remains & $* * *$ \\
\hline Gastropods (small forms) & $* *$ \\
\hline Pharetronid sponges & $* *$ \\
\hline Serpulids & $* * *$ \\
\hline
\end{tabular}

* single specimen, $* *$ rare, $* * *$ common, $* * * *$ abundant

The ammonite biostratigraphic analysis carried out along the marls of the Forcall Formation by Moreno-Bedmar et al. $(2009,2010)$ permits us to ascribe this encrusted horizon to the upper part of the Deshayesites forbesi biozone (Lower Aptian) (Fig. 2). The occurring orbitolinids Palorbitolina lenticularis (Blumenbach) and Praeorbitolina gr. cormyi-wienandsi Schroeder confirm the Lower Aptian age of the deposits (Schroeder 1975).

\section{Material}

The material studied comprises 73 thin sections, which were sampled from nine different outcrop sections in the vicinity of the towns of Aliaga, Montoro de Mezquita, Camarillas and Miravete de la Sierra (Teruel province, Spain; Fig. 1). Besides the material from the Lower Aptian, detailed pictures from Elliott's holotype and paratypes were kindly provided by the Natural History Museum in London (NHM). At the NHM, Elliott's original thin sections are kept under the following numbers:

- holotype, original Reg. no. Ru 191 (pl. 1/5 of Elliott 1956) > NHM no. V41600

- paratype, original Reg. no. Ru 192 (pl. 1/2 of Elliott 1956) > NHM no. V41597

- paratype, original Reg. no. Ru 193 (pl. 1/4 of Elliott 1956) > NHM no. V41599.

The study was complemented by several figurations kindly provided by the following colleagues (the stratigraphy of the samples is given in brackets): Ioan Bucur and Emanoil Săsăran, Cluj-Napoca (Tithonian of Romania), Stefan Götz, Heidelberg (Hauterivian of the central Maestrat Basin, Spain), Boguslaw Kolodziej, Kraków (TithonianBerriasian of Poland), Rajka Radoičić, Belgrade (Valanginian of Serbia).

\section{Terminology}

According to Golubić et al. (1981), the microorganisms capable of boring the substrate can be classified as follows: chasmoendoliths (inhabiting fissures in rocks open to the surface), euendoliths (actively boring into the substrate) and cryptoendoliths (settling in existing cavities). The general term for these three categories is endoliths, and epiliths for taxa that settle on the substrate surface. As stated by Wisshak (2006, p. 23) the boundaries are not always drawn precisely since epilithic organisms may have euendolithic stages. Algae that live inside other living algae, either actively boring into the tissue or just as cryptoendoliths inside existing internal structures, are called endophyts independently of the net impact of this association (i.e., beneficial or harming) (e.g., Correa 1994). For the observed boring structures, a maximum width of $0.1 \mathrm{~mm}$ is considered as the boundary between microborings and macroborings (e.g., Golubić et al. 1975; Glaub 1994; Wisshak 2006; Glaub et al. 2007). Empty boring structures are here treated ichnotaxonomically independently of whether it is known or unknown what produced them (e.g., Schmidt 1992; Glaub 1994; Bertling et al. 2006; Glaub et al. 2007). It should be noted that the ichnotaxonomic concept represents a pure morphological approach so that different ichnospecies 
of the same ichnotaxon may be assigned to totally different biogenic groups as producers. These three-dimensional patterns are usually studied using resin borehole casts (cast embedding technique, Golubić 1983); thus, transferring two-dimensional characterizations obtained from thin-section studies to individual ichnogenus/-species is highly problematic, and usually impossible. When combining thin sections cut at different levels, at least a tentative assignment is possible.

When discussing the different taxonomic interpretations of Lithocodium found in the literature, the terms calcimicrobes and microbial carbonates (or microbialites) are used. For pragmatic reasons, these tiny filamentous-branching and tubiferous microorganisms (e.g., cyanobacteria) are here neutrally termed calcimicrobes (= microbes capable of triggering carbonate precipitation) (e.g., Riding 2000; Shen and Webb 2008) in a broader sense (e.g., Leinfelder et al. 1993) as the taxonomic status of these forms is still insufficiently known. One previous concept of fossil calcified cyanobacteria provided by Riding (1991a) included a variety of taxa of uncertain taxonomic status (microproblematica); some authors equate calcimicrobes with cyanobacteria, others also include problematic cyanophyta such as the porostromate algae (Shen and Qing 2008, "porostromate calcimicrobes"). The wide calcimicrobial approach used here permits the informal grouping of heterogeneous taxa of different suprageneric taxonomic positions and also of different morphologies. Microbial crust (or microbialite) has been defined in the literature as an organosedimentary deposit (here: microbial carbonates) of benthic microbial communities (Burne and Moore 1987; Riding 1991b, 2000; Schmid 1996; Browne et al. 2000).

\section{Description of the crusts}

A detailed description of the lithology and microfacies of the Lower Aptian Lithocodium-bearing coral rubble deposits is given by Bover-Arnal (2010) (see also Segonzac and Marin 1972). The following information essentially refers to the description and understanding of the Lithocodium-type micritic crusts; further details on the internal morphology are given in the paleontologic-systematic part of the paper.

The thin sections studied are composed mainly of three components: (I) coral rubble ( $\sim 95 \%$ of the order Microsolenina) and more rarely rudistid fragments or oyster shells encrusted by (II) Lithocodium aggregatum Elliott (e.g., Fig. 3a) and surrounded by a (III) fine-grained matrix exhibiting terrigeneous input. The matrix typically contains flat disk-shaped tests of Palorbitolina lenticularis (Blumenbach), which occasionally became encrusted (Fig. 3b). The thickness of the micritic Lithocodium aggregatum-crusts varies (Fig. 3a, c). Discordant layering indicates overturning
Fig. 3 Microfacies of Lithocodium-crusts from the Lower Aptian coral rubble deposits of the western Maestrat Basin. a Several (mostly comparable thin) crusts of Lithocodium aggregatum Elliott superimposed upon coral bioclasts infested by Bacinella irregularis Radoičić; note discordant growth of crust layers indicating erosion and overturning. b Thick crusts embedding recrystallized bioclast $(b c)$ and the test of an orbitolinid foraminifera (dashed white line); note the various specimens of Bacinella irregularis Radoičić (arrows) boring inside the crusts. The orientation of the crust surfaces (white solid lines) in different directions (upwards/downwards) evidences multi-phase encrustations and overturning. c Rudistid shell with encrustation of Lithocodium aggregatum Elliott on both sides; note the comparably slight bioerosion of the shell and the reduced number of crust layers. $d$ Encrustation succession of Lithocodium aggregatum Elliott and the arenaceous benthic foraminifer Bdelloidina? urgonensis Wernli and Schulte $(B)$; note the absence of micritization of lower crust layers. $\mathbf{e}$ Several (presumably three) crust layers of Lithocodium aggregatum Elliott upon coral substrate infested by Bacinella irregularis Radoičić (B). The comparably thick crust results from oblique sectioning (compare a, c-d). f Detail from e showing micrite-filled filamental structures of Lithocodium aggregatum in the two lowermost crusts (white dashed lines) following the substrate and outer crust layer with sparitefilled filaments (cut transversely and obliquely). g Ichnogenus Entobia within coral bioclasts produced by boring sponges; note the channel to the surface (right side). h Gastrochaenolites ichnosp., macroboring produced by lithophagid bivalves affecting both substrate and crusts of Lithocodium aggregatum Elliott. Boring filled with stratified finegrained sediment (geopetal filling); note the pyrite-stained boundary at the crust-boring boundary. Scale bars $1 \mathrm{~mm}$, except $\mathbf{f}=0.5 \mathrm{~mm}$. Thin sections: a CA-3H, b SE-4V, c PO-1V, d CC-4V, e-f H0-16H, g CAL$2 \mathrm{~V}, \mathbf{h}$ SE-2H

(Fig. 3a). Accompanying crustose microbiota, switched between these crusts, include bryozoans, the red alga Polystrata alba (Pfender) and quite often the arenaceous foraminifera Bdelloidina? urgonensis Wernli and Schulte. None of these taxa occur as pioneer encrusters. Interestingly, within a crust succession of alternating layers of Lithocodium aggregatum Elliott and Bdelloidina? urgonensis Wernli and Schulte, siliciclastic particles only became incorporated into the foraminiferan test of the latter (Fig. 3d). Internally, the majority of the crusts seem to be completely structureless at first sight, however, several crust layers with micrite-filled internal structures are often dimly recognizable (Fig. 3e, f). Within the outermost crusts, which exhibit smooth surfaces, these structures are sparite-filled and well discernible. Thus, thick crusts are in fact composed of superimposed individual layers. Both Lithocodium-crusts and bioclasts display intense signs of bioerosion. Boring galleries made by endolithic sponges (Entobia) occur within the encrusted bioclasts (Fig. 3g). Borings of lithophagid bivalves (Gastrochaenolites) may affect both bioclasts and the surrounding micritic crusts, thus post-dating the crust-formation and indicating rapid lithification (Fig. 3h). Both ichnogenera Entobia and Gastrochaenolites were identified with approximately equal abundances in the thin sections studied. Moreover, the coral rubble shows intense bioerosion by chlorophyte algae, as described in the paleontological section of this work obvi- 


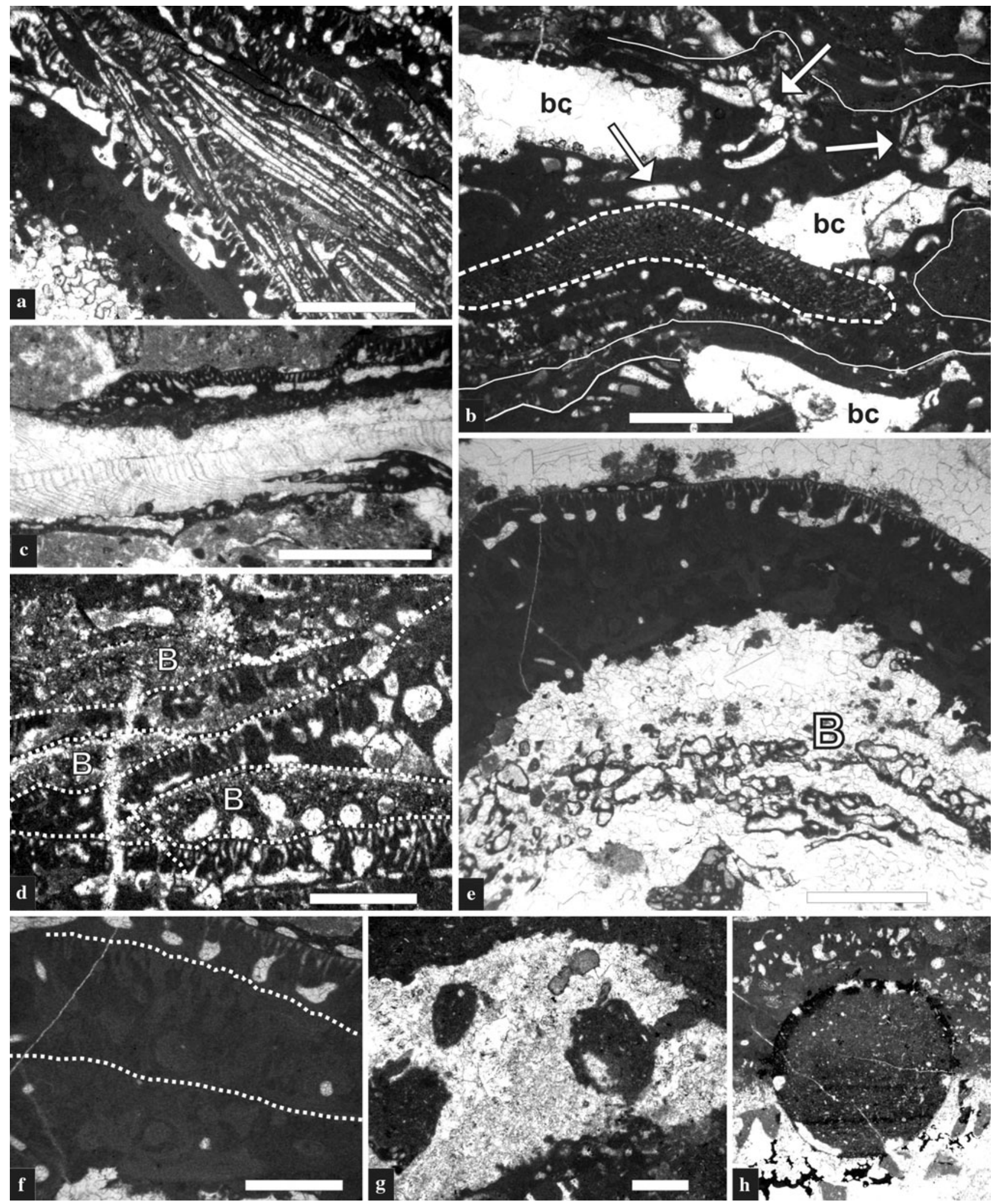

ously infecting the coral skeletons even before the encrustation by Lithocodium aggregatum (Fig. 3e). It is assumed that the corals became encrusted after their death; in this respect, corals in life position lacking Lithocodium-crusts or showing only minor encrustation were reported from other parts of the study area (Bover-Arnal 2010). 


\section{Interpretation of the crusts}

The micrite enveloping the filaments of Lithocodium was assumed by Segonzac and Marin (1972) to be calcified mucilage produced during the lifetime of the organisms. Koch et al. (2002, p. 84) assumed that the crusts possess a primarily Mg-calcite mineralogy with crystals $<1 \mu \mathrm{m}$, which were slightly recrystallized to micrite $(<4 \mu \mathrm{m})$. In fact, in the smooth outer crust surface, the thin distal covering of the terminal filaments and the dense homogeneous microcrystalline texture where the filaments are completely embedded, correspond to calcified organic algal tissue (possibly in vivo micritization). A micritic thallus composition is also known in exceptional cases from some dasycladalean green algae such as the Late Jurassic Salpingoporella? sellii (Conrad and Varol 1990; De Castro 1997, p. 204, "pores...included in a...micritic, common collective sheath"). This common collective sheath is different from that of the group Rivulariaceae-Porostromata with individually sheathed filaments (e.g., Dragastan et al. 1996), indicating impregnation of the cyanobacterian sheaths with calcium carbonate (e.g., Riding 1977; Merz and Zankl 1993). SEM photographs of Lithocodium show "extreme equally granular, homogeneous micrite and minimicrite" (Neuweiler and Reitner 1992, p. 278, translated; see also SEM pictures in Banner et al. 1990). As inclusions, primary anhedral micrite is still recognizable, which, according to Neuweiler and Reitner (1992, p. 278) could correspond to biominerals produced within an organic medium. Following these authors, such observations are generally compared to calcified cyanobacteria where minimicrite is typically found (e.g., Flügel 2004, p. 75). Minimicrite may also be produced by multicyclic boring and concurrent filling of boreholes (Reid and Macintyre 2000). This possibility becomes important since the Lithocodium-crusts underwent intense macrobioerosion and microbioerosion with complete micritization of former boring galleries and algal filaments. In any case, an early or primary lithification is also evidenced by an initial boring of superimposed crusts into the lower one or the penetration by lithophagid bivalves (Fig. 3h).

The non-agglutination (actively to some extent) or trapping (passively) of the available silt-sized quartz grains by Lithocodium crusts is well documented, especially in the cases where the crusts occur in alternation with the encrusting foraminifer Bdelloidina? urgonensis Wernli and Schulte which incorporates the siliciclastics in its test wall (Fig. 3d). If Lithocodium should correspond to a microbial colony or microbial mat, trapping of the available foreign material deposited on the mat surface would be expected in our case (e.g., Riding 2000; Browne et al. 2000; Gall 2001; Noffke 2008), as also required in the definition of microbialite as an organosedimentary deposit (Burne and Moore
1987). Schmid and Leinfelder (1996, fig. 3) illustrated a "Lithocodium"-nodule together with the cryptobiotic foraminifer Troglotella incrustans Wernli and Fookes displaying incorporated (agglutinated) detrital quartz. The relationship of these Upper Jurassic forms and the Lower Cretaceous Lithocodium aggregatum Elliott are discussed later in the paper.

The dense dark micritic appearance and the smooth crust surface are also non-typical features of microbialites. Microbial crusts should, furthermore, show characteristic microfabrics (laminated, clotted, peloidal) (e.g., Keupp et al. 1993; Schmid 1996; Riding 1991b, 2000) and various microencruster intimately involved in crust formation (e.g., Leinfelder et al. 1993; Schmid 1996; Dupraz and Strasser 1999). Moreover, none of the authors who discuss the possible cyanobacterian nature of Lithocodium aggregatum take into further consideration the fact that filament diameters of cyanobacterians cover a range several orders smaller than those exhibited by the Lithocodium aggregatum (e.g., Le Campion-Alsumard 1979; Chafetz and Buczynski 1992; Stal 2007; Foster et al. 2009). As will be shown in the following chapter, the filamentous thallus architecture can convincingly be included in chlorophyte algae structure.

\section{Systematic paleontology}

In this chapter, the holotype figurations of both Lithocodium aggregatum and Bacinella irregularis supplemented by the paratype material and the original descriptions are critically commented on, bearing in mind our observations of the Lower Aptian specimens from the western Maestrat Basin that we studied. Detailed descriptions with emendations of both Lithocodium aggregatum Elliott and Bacinella irregularis Radoičić are then presented. Finally, other euendolithic/endophytic taxa, calcimicrobes, and ichnotaxa characteristically associated with the Lower Cretaceous Lithocodium crusts are also described.

Comments on the type-material of Lithocodium aggregatum Elliott

As already remarked, Elliott's material is deposited at NHM. Details from the holotype and paratype "specimens" are illustrated in Fig. 4. The holotype (Elliott 1956, pl. 1/5) is represented by both large "nodular" masses and by thin crusts growing upon the skeleton(s) of the stromatoporoid Burgundia cf. ramosa Pfender (Fig. 4b, f). Not mentioned in the original description, Elliott (1963, p. 294) some years later remarked, that "Lithocodium is itself often intimately intergrown with the lamellar stromatoporoid Burgundia". The apparent occurrence of two morphotypes accounted for the original genus characterization as "encrusting or 
nodose" (Elliott 1956, p. 331). It is noteworthy that such a co-occurrence of two different morphotypes within the same sample is curious if not remarkable with respect to paleoenvironmental interpretation (see Rameil et al. 2010). Elliott (1956 p. 328), however, stressed that Lithocodium often "show $(s)$ several superimposed thalles", a character that obviously has been responsible for the species name: aggregatum. Our research has shown that apparently, the thick nodular thallus corresponds in fact to several superimposed thalli and, moreover, that greater individual crust thicknesses can result from oblique sectioning (Fig. 4b). Elliott's "inner layer" of filaments was compared with the medullar zone of codiacean algae, which should be composed of a "confused inner layer" with "very irregularly disposed coarse filaments without definite orientation". However, within the thin-crustose part of the holotype (Elliott 1956, pl. 1/5, lower right) this "inner layer" shows a very regular arrangement parallel to the crust and substrate surfaces (Fig. 4f). Only in the thicker "nodular" parts, irregular arrangements, often obliquely organized "coarse filaments" prevail and partly correspond to empty boring galleries (e.g., Fig. 4b, d): an ichnofabric produced by (micro-)bioeroding taxa. The overall presence of (micro)borings within the Lithocodium tissue as a characteristic feature is well recorded in the material from the Lower Aptian of Spain, but is also present in the type-material of Elliott, the Lower Cretaceous of the Middle East (Banner et al. 1990) and the Hauterivian of Spain (Götz et al. 2005) though not mentioned in these works. Another type of microboring is represented by thin, slightly undulating channels with irregular distributed ovoid swellings. The supposedly irregular disposition of the inner (medullar) zone is furthermore given in oblique crust sections with the branching prostrate filaments as described in the present paper. This is clearly visible in the paratype shown by Elliott (1956, pl. 2/4) also with a boring obliquely transjecting the algal crust (Fig. 4g).

Both the oblique-sectioned substrate-parallel branching filaments and the obliquely arranged borings were obviously intermingled by Elliott (1956) as filaments of a "medulla". When reviewing the literature, it is evident that not only Elliott (1956) but most subsequent authors had problems with the assignment of the "medulla". In the work of Banner et al. (1990) for example, "tubular filaments" parallel to the crust surface from which branching "cortical filaments" arise and also cellular structures occurring in borings of the basal substrate, were regarded as "medullary filaments" (Banner et al. 1990, p. 30, "medullary filaments....fill these borings"). In addition, the irregular "bacinellid" cellular structures that may trap bioclasts were assigned to the medulla (Banner et al. 1990, p. 30, "skeletal fragments may be...encapsuled during the growth of the medulla"). A trapping of foreign material within the medul- lar zone of a "codiacean" alga is more than strange, and has not been observed in any other species in this group (e.g., Bassoullet et al. 1983).

In any case, neither more details in the description (e.g., dimensional data, etc.), nor detailed views (referring to the description), were provided by Elliott. Thus a definite and unequivocal interpretation of what Elliott understood as the taxon Lithocodium is not possible. Neither did Elliott describe the crusts as being composed of different taxa. Obviously, assuming that, besides the micritic crust/mass, all observable internal microstructures belong to Lithocodium.

In conclusion, the holotype cannot serve as a type, since the correct identification of the details of the internal structures of Lithocodium aggregatum is not possible. Also, the short original description, together with the low magnification of the three thin-section photographs, were difficult to interpret for subsequent authors, as indicated by the decades of controversy in the literature. Therefore, the designation of the crust-forming filamentous algae as Lithocodium aggregatum Elliott and the redescription of the genus Lithocodium Elliott is the way we have decided to choose not only to solve at least to some extent the existing taxonomic-ichnotaxonomic mixture but also to reinforce the validity of the genus Lithocodium Elliott. In our case, article 9.7 of the International Code of Botanical Nomenclature (ICBN) can be applied stating that "when the holotype, lectotype, or previously designated neotype, or all original material associated with a validly published name, is demonstrably ambiguous and cannot be critically identified for purposes of the precise application of the name of a taxon"....an epitype can be established as "a specimen or illustration selected to serve as an interpretive type". When an epitype is designated, the holotype, lectotype, or neotype that the epitype supports must be explicitly cited" (Vienna Code) (McNeill et al. 2006; Hyde and Zhang 2008 for further discussion). Therefore, in order to permit a precise application of the name Lithocodium aggregatum, we here designate an epitype according to article 9.7 ICBN selected from Elliott's holotype (1956, pl. 1/5, original number Ru.191) stored at NHM under the number V41600 and illustrated in the present paper in Fig. 4f. In addition, a part of the holotype showing a single-layered crust (or thallus) cut in a more or less perpendicular plane with respect to the substrate has been chosen as the epitype since Elliott (1956) already recognized that the nodular masses are composed of superimposed thalli which are clearly visible in one paratype of Elliott (1956, pl. 1/2). Besides the cross-walls in the "medullar" filaments sensu Elliott (Segonzac and Marin 1972; Banner et al. 1990) already mentioned, the "cortical filament(s)" are also septate (Fig. 4a, c). Due to the constrictions, the "medullary filaments" sometimes appear discontinuous in sections that do not pass directly along the 
median plane (Figs. 3c, 4f). This feature is incompatible with a codiacean/udoteacean non-septate siphonous structure (see Bassoullet et al. 1983; Mu 1991), hence, the septate filaments are described in terms of a basal prostrate and an erect filament system. In addition, the material from the western Maestrat Basin provides morphological details that were not evidenced in the three illustrations of the original work, namely a euendolithic unicellular sporophytic stage, a chasmoendolithic basal part in the cases of sculptured or fissioned substrate surfaces, and an irregular vesicular final stage. The morphological details are furthermore supplemented by the description of euendolithic/cryptoendolithic taxa within Lithocodium, several ichnotaxa and associated calcimicrobes.

\section{Emended description of Lithocodium aggregatum Elliott}

Remarks The taxonomy used refers to the online database (AlgaeBase) from Guiry and Guiry (2009). The evidently cellular, septate (= with regular crosswalls) thallus structure of Lithocodium aggregatum Elliott excludes its inclusion in siphonous green algae, e.g., Udoteaceae (= former Codiaceae) (e.g., Bassoullet et al. 1983; Mu 1991) as stated previously. Banner et al. (1990) introduced the Lithocodoidea as a subfamily within the Codiaceae and curiously redescribed Lithocodium as possessing irregularly septate subdermal filaments. Within this subfamily, the two genera Lithocodium Elliott (assumed to be monospecific) and Radoicicinellopsis Banner, Finch and Simmons (monospecific, based on Bacinella sterni) were included. It is, however, doubtful that Radoicicinellopsis sterni belongs to siphonous green algae (e.g., Masse 1979; Leinfelder 1985). Therefore, the validity of the Lithocodoidea is challenged.

The suprageneric position (family) of Lithocodium aggregatum cannot be fixed precisely. Its belonging to the class Ulvophyceae is justified by the supposed occurrence of a "Codiolum" stage in the life cycle of Lithocodium (e.g., Pröschold and Leliaert 2007); taxa that can be compared with Lithocodium such as Eugomontia Kornmann or Gomontia Bornet and Flahault or those co-occurring such as Phaeophila-type or Acrochaete-type are included in the order Ulotrichales Wille (see Guiry and Guiry 2009). To the best of our knowledge, Lithocodium cannot be assigned to any extant taxa.

\section{Division: Chlorophyta \\ Class: Ulvophyceae \\ Order: Ulotrichales? \\ Family: ? \\ Genus: Lithocodium Elliott 1956}

Original diagnosis Encrusting or nodose Codiaceae with a subdermal structure similar to that of the segmented Boueina (Elliott 1956, p. 331)
Fig. 4 Detailed views of Lithocodium aggregatum Elliott, holotype: d-f, h (Elliott 1956, pl. 1/5), paratype: a, c (Elliott 1956, pl. 1/2), paratype: b, $\mathbf{g}$ (Elliott 1956, pl.1/4). a, c Detailed views showing the upright branching septate filaments rising from substrate-parallel prostrate septate filaments; crosswalls: of erect filaments in orange, of the prostrate filaments in red; note finger- to palisade-like appearance of filaments. b Oblique section of Lithocodium aggregatum Elliott fixed to the stromatoporoid Burgundia cf. ramosa Pfender $(S)$; note the various borings ( $B$, and white arrows; d-e: details in Fig. 17e-f). d Branching boring galleries within crust of Lithocodium aggregatum. e Oblique section of Lithocodium aggregatum; inside the crust parts of the skeleton of Burgundia cf. ramosa Pfender (arrows) are discernible. f Comparable flat crusts infested by Lithocodium aggregatum switched between encrusting stromatoproid skeletons of Burgundia $\mathrm{cf}$. ramosa Pfender; specimen showing the prostrate crust-parallel swollen septate filament from which branching filaments rise stretching towards the crust edge; this detail from the holotype is taken as interpretative epitype (article 9.7 ICBN). g Oblique section, detail from $\mathbf{b}$. h Oblique section of Lithocodium aggregatum cutting the thick crust-parallel swollen filaments. Scale bars $1 \mathrm{~mm}$ for $\mathbf{b}, \mathbf{d}, \mathbf{f}, \mathbf{h} ; 0.5 \mathrm{~mm}$ for $\mathbf{g} ; 0.3 \mathrm{~mm}$ for a, c. Thin sections: a, c V 41597, d-f, h V 41600, b, g V 41599. Copyright for $\mathbf{a}-\mathbf{h}$ Natural History Museum, London

Emended diagnosis Encrusting epilithic alga with a possible heteromorphic life including a multicellular gametophyte and a unicellular sporophyte (Gomontia stage). Euendolithic sporophyte (Gomontia stage) bag-shaped with several branching or non-branching excrescences/appendages at its surface; special exit tubes for the release of the zoospores may be present. In cases of fissured or sculptured substrate surfaces, a basal vesiculiferous chasmoendolithic stage can be developed. Gametophyte thallus with heterotrichous organization differentiated into a ramified system of prostrate creeping septate filaments from which an erect system of septate branching filaments arise. Prostrate creeping filaments thick and with constrictions at irregular distances. Depending on the crust thickness, the erect filament system may be strongly reduced or well developed with successive branching in several layers; towards the smooth crust surface final filaments are covered with a thin sheet. The terminal stage may be constructed by large irregular cells directly arising from the prostrate filaments without preserved erect branching filaments; only their terminal part may be preserved as a zagged micritic rim. Thallus of dark microcrystalline calcite forms a common sheath where the filaments are embedded.

Lithocodium aggregatum Elliott 1956 (Figs. 3a, c, b-e pars, f, h pars, 4a-h, 5a-e, g, i, 6a-g, 7a-i, 8a-d, 14a pars, $15 a-f$ pars, $17 a-j$, pars)

Synonymy The complex assemblage of euendolithic and endophytic chlorophytes accounts for the fact that in most cases, illustrations of Lithocodium aggregatum in the literature often also include other taxa that we have not tried to decipher in detail. In other cases, the low magnification does not allow a definitive identification. Furthermore, 


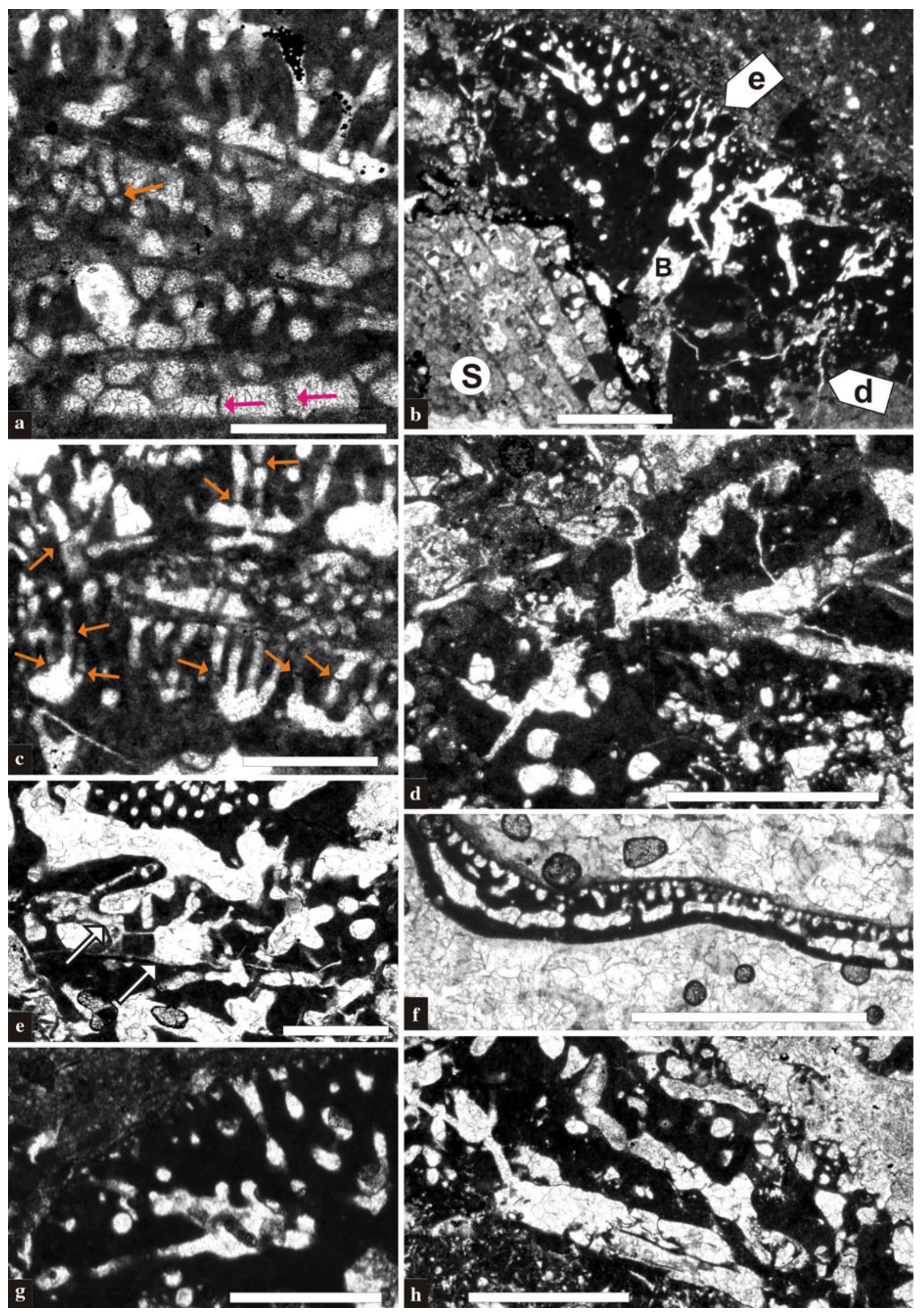


Fig. 5 Euendolithic unicellular sporophytic Gomontia stage referred to Lithocodium aggregatum Elliott from the Lower Aptian of the western Maestrat Basin (a-b, d-e, g), the Upper Jurassic (Late Tithonian) of the Northern Calcareous Alps of Austria (c), Valanginian of Serbia (i) in comparison to modern Counterparts (f, h). a Two solitary large variable sack-like sporophyts with rhizoid-like branching appendages; note the micritic lining between the substrate and the sporophyte. The specimen on the left shows two large tubes which in turn exhibit finer appendages. b Two differently shaped sporophyts spreading with their upper appendages into a thin crust of Lithocodium aggregatum Elliott. c Ovoid sporophyte with two appendages. $\mathbf{d}$ Two specimens boring into a rudistid shell; right specimen with long tubes (possibly exit tubes) cutting across the crust and grading into large sparite-filled cells (compare Fig. 8). e, g Oblique sections of boring sporophyts of irregular star shapes. f Cultivated sporophyts of Gomontia polyrhiza (Lagerheim) within a bivalve shell; note the large morphological variability (thickness, height, appendages), combined from Kornmann (1959, figs. 7 and 9). h Same as e and $\mathbf{g}$, cultivated sporophyts within bivalve shells (redrawn from Kornmann 1959, fig. 8e). i Several sporophyte stages within rudistid shell, Valanginian of Serbia (from Radoičić 2005, pl. 6/8). Scale bars $0.2 \mathrm{~mm}$ for all figurations. Thin sections: a CA2H, b H0-6V, c Die-170, d P0$1 \mathrm{~V}$, e CAL-6V, g H0-4V
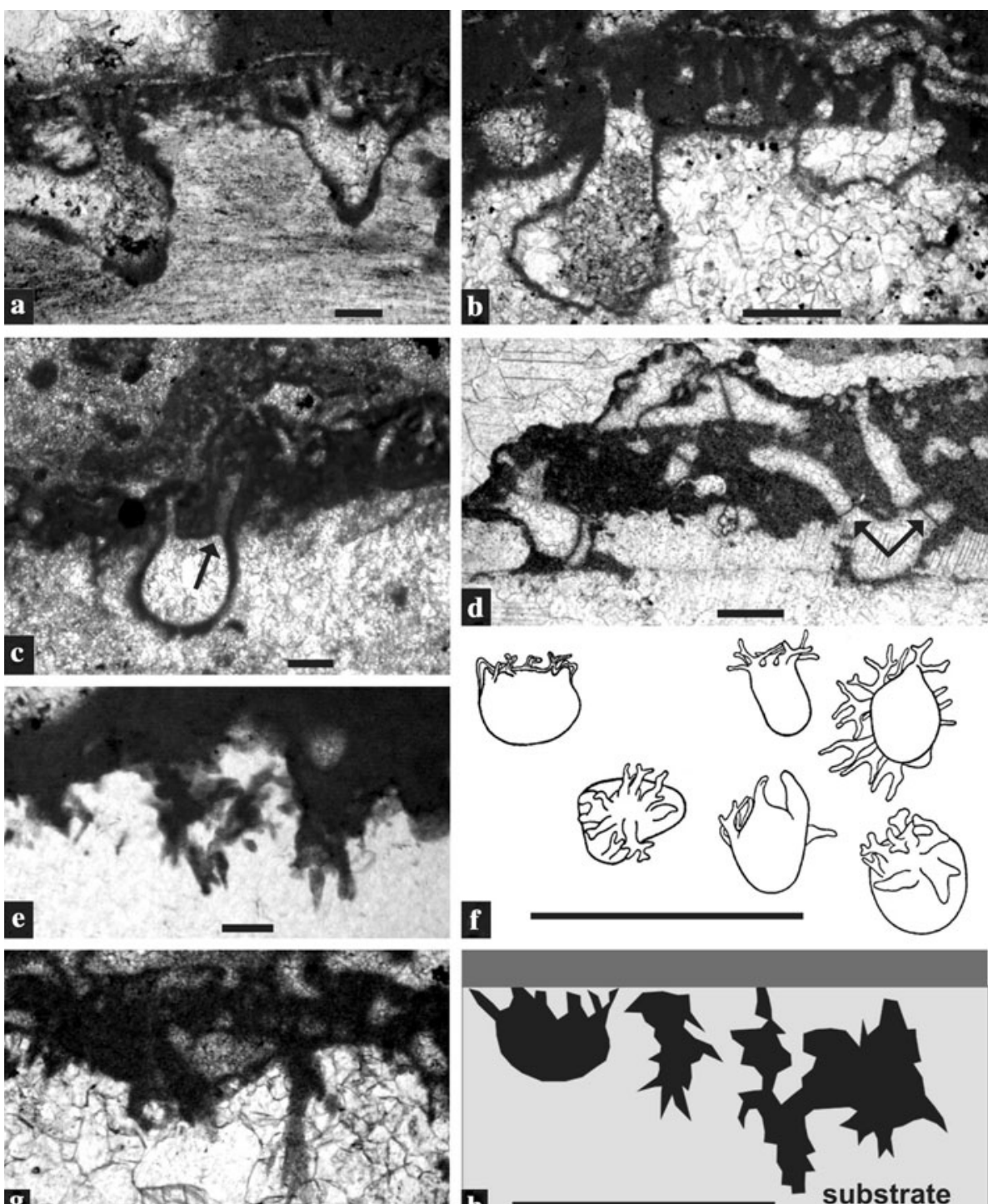

f
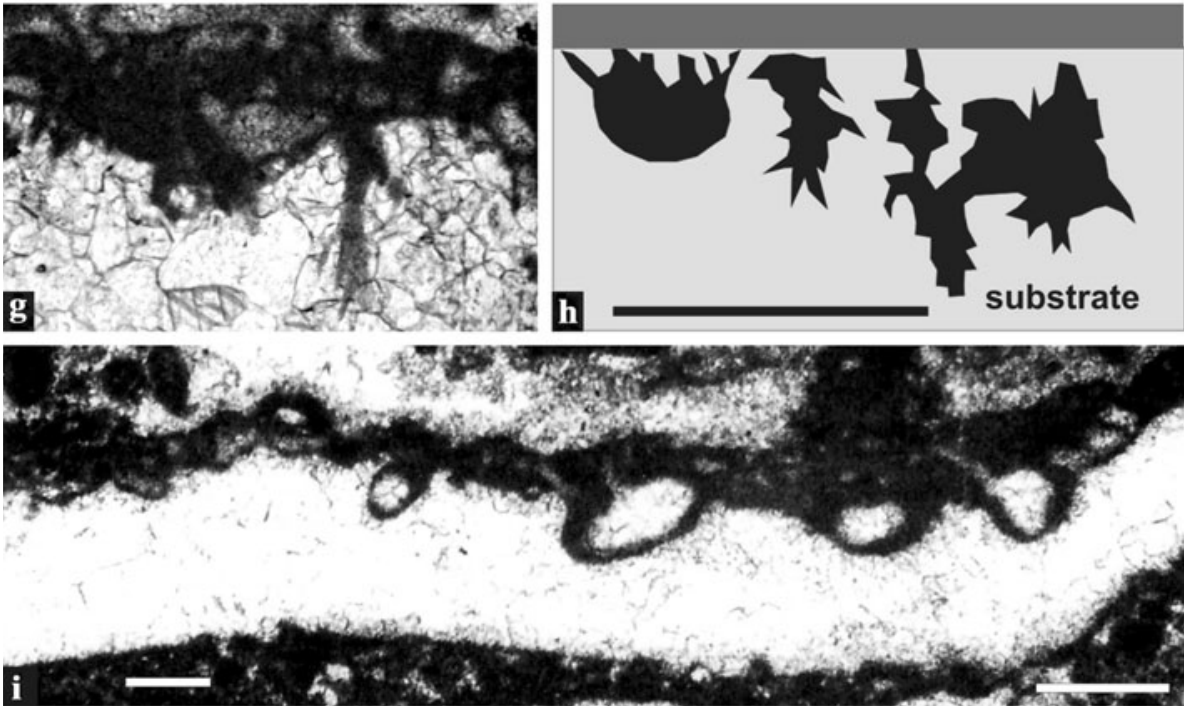

several (though not all) Late Jurassic references cannot be included as they are morphologically different; the same holds for all the Late Triassic reports that definitely cannot be included in the presented emendation of Lithocodium aggregatum Elliott. Therefore, only a small subjective choice of references is given including those discussed in the present paper, some poorly known or those from more recent publications.
*1956 Lithocodium aggregatum nov. gen., nov. sp. Elliott, pl. 1/2, pl. 1/4-5

1972 Lithocodium aggregatum Elliott - Segonzac and Marin, pl. 1/1-8

1979 Lithocodium aggregatum Elliott - Luperto Sinni, pl. 41/1-2, 4-6

1979 Lithocodium morikawai Endo - Mišík, pl. 2/1

1982 Dehornella sp. - Jansa et al., pl. 6/1-3 

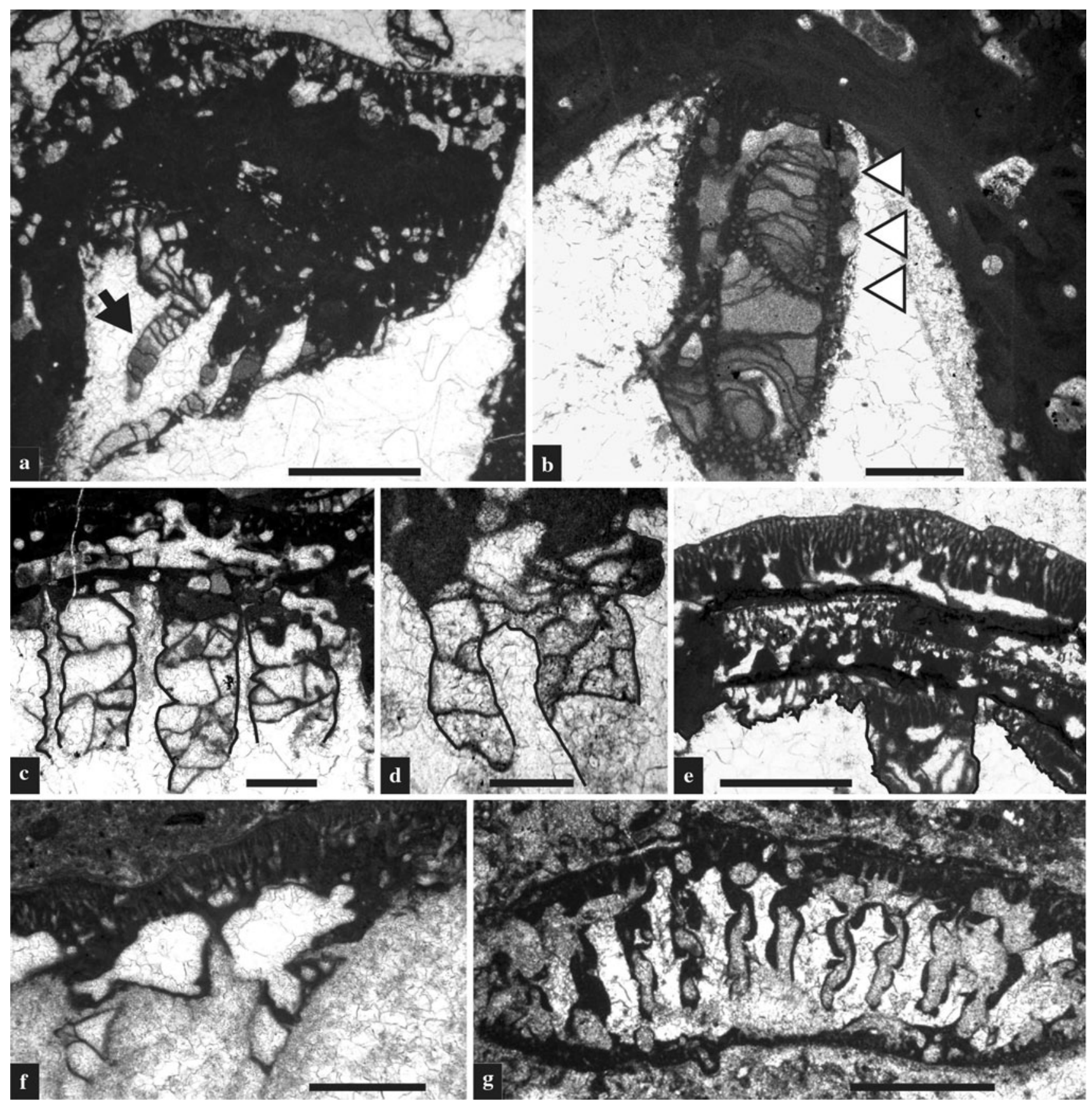

Fig. 6 Chasmoendolithic (a, c-g) and pseudochasmoendolithic (b) filling stage of Lithocodium Elliott from the Lower Aptian of the western Maestrat Basin (a-e) and the Upper Jurassic of Poland (f) and Romania (g). a Chasmoendolithic fillings (arrow) within coral bioclasts. b Pseudochasmoendolithic filling structures within Gastrochaenolites ichnosp. The macroboring became encrusted by Lithocodium aggregatum Elliott at its base (arrows), then developed the irregular-vesicular final stage with cells filled with microsparite; later the clast with its completely filled macroboring became overlaid by various Lithocodium layers (with micritzed filamental structures). c, d Chasmoendolithic fillings in interseptal space of corals; simple crosspartitions in voids of reduced width (e.g., $\mathbf{d}$ left) and house-of-cards structures in broader voids (c, $\mathbf{d}$ right). e Several crust layers of Lithocodium aggregatum Elliott; note the development of prostrate and erect filament systems within the void. f Chasmoendolithic filling stages of Lithocodium sp. in sculptured coral surface; note the transition into large irregular basal cavities (from Kolodziej 1997; TithonianLower Berriasian Stramberk-type limestone of the Polish Carpathians). g Chasmoendolithic fillings of Lithocodium sp. in interseptal spaces of a coral; note the thick micritic linings, Tithonian Sandulesti Limestone Formation, Trascau Mountains of Romania, see Săsăran et al. (2001). Scale bars $0.5 \mathrm{~mm}$ for a, c, d, f; $1.0 \mathrm{~mm}$ for $\mathbf{b}, \mathbf{e}, \mathbf{g}$. Thin sections: a PO-1V, b CUB- 4, c, d DE-4H, e H0-16V, f partly from Kolodziej (1997, fig. 2 g), g leg. Ioan Bucur 
1985 Lithocodium-Kruste, Bacinella irregularis Höfling, pl. 3/5-7

1987 Lithocodium aggregatum - Reitner, pl. 21/2, pl. $49 / 16$

1990 Lithocodium aggregatum Elliott (pars) - Banner et al., pl. 1/1-4, pl. 2/1-4, pl. 3/1, pl. 4/1

1994 Lithocodium aggregatum Elliott - Grötsch et al., pl. $3 / 8$

2004 Lithocodium aggregatum - Bucur et al., pl. 2/24

2005 Lithocodium aggregatum Elliott, microbialite aff. KL 18, Lithocodoidea - Radoičić, pl. 5/1-8, pl. 6/1-4, 8, pl. 7/1-2 (pars), pl. 8/3-6, 9

2005 Lithocodium crusts - Götz et al., figs. 6a-d

2006 Lithocodium aggregatum - Cherchi and Schroeder, figs. 1-3 (pars)

2008 Lithocodium aggregatum Elliott - Conrad and Clavel, figs. 5-7

Description The description takes into account the assumed heteromorphic life cycle and the optional occurrences of morphologically discrete basal and final stages. For clarity, remarks are given after each part of the description, which is divided up as follows:

- euendolithic Gomontia stage

- chasmoendolithic basal stage

- epilithic filamentous stage

- vesicular terminal stage.

\section{Euendolithic Gomontia stage (Fig. 5a-e, g, i)}

The euendolithic sporophyte stage (sporangia) is represented by differently shaped (e.g., ovoid, bag-, sack-like) swollen cells bored into the calcareous substrates, for instance rudistid shells (Fig. 5a-d, i). Morphologically variable, it includes forms that are wider than they are long and vice versa; forms widening upwards or becoming narrower. The base may be rounded, almost spherical or tapering. Occasionally, at the base or the transition to the appendages, micrite fills the space between the algal borings and the surrounding substrate; in other cases the bags fit closely inside the boring. The top is represented by branched or unbranched appendages spreading into the micritic crusts; some of them are distinctly larger (? exit tubes) touching the crust surface but not breaking through it (Fig. 5b, d). In oblique and transverse sections, irregular star-like micritic borings are discernible (Fig. 5e, g).

Remarks The Lower Cretaceous findings are directly comparable to the sporophyte stages of modern ulotrichalean algae (Fig. 5f, h), usually termed Codiolum stage (or Gomontia stage, e.g., Kornmann 1959; Nielsen 1987) referring to the species Gomontia polyrhiza (Lagerheim) (former Codiolum polyrhizum) and previously described as a separate taxon. A Gomontia stage may be present in spe-
Fig. 7 Epilithic stage of Lithocodium aggregatum Elliott from the Lower Aptian (a, b, d-i) and Hauterivian (c) of the Maestrat Basin. a Several superimposed crusts exhibiting discordant layering indicating movement/erosion; note the strongly reduced erect-branching system in the uppermost crusts (upper left). b Several superimposed crusts with boring in the uppermost layers (white arrows), the entrance point of the boring taxon (most probably a chlorophyte alga) is marked with (E). In the lower part, a sack-shaped euendolithic stage of Lithocodium is visible (contour marked by the solid white line) from which creeping prostrate filaments stretch in various directions. c, d Oblique sections showing the low-angle branching prostrate system (c from Götz et al. 2005). e Detailed view of the erect filament system with several layers of branchings easily recognizable by the dark pyritic fillings. f Oblique section, cutting two superimposed crusts on a coral substrate. $\mathbf{g}$ Detail from the multi-layered crusts shown in a (a different part of the thin section) almost perpendicular to the substrate showing both prostrate and erect filament systems with transverse partitions (arrows). h Oblique section of several superimposed crusts showing low-angle branching prostrate system (white arrows). i Several superimposed crusts (dashed white lines), in between arenaceous foraminifer Bdelloidina? urgonensis Wernli and Schulte $(B)$ and boring gallery $(B o)$; $S=$ substrate. Scale bars $0.5 \mathrm{~mm}$ for $\mathbf{a}, \mathbf{b}, \mathbf{e}, \mathbf{g}, \mathbf{h} ; 1.0 \mathrm{~mm}$ for $\mathbf{c}, \mathbf{d}, \mathbf{f}, \mathbf{i}$. Thin sections: a CA-3H, b H0-16V, c H0-3VB, d SE-2V, e CUB-1, f DE-4V, g CA-3H, h CA-3H, i Ho-3V

cies of several euendolithic genera such as Collinsiella Setchell and Gardner, Eugomontia Kornmann, Gomontia Bornet, and Flahault and Monostroma Thuret (e.g., Setchell and Gardner 1903, 1920; O'Kelly et al. 2004), but also in non-euendolithic taxa such as Urospora Areschuog or Acrosiphonia Agardh (Kornmann 1959, 1961, 1962; Sussmann and DeWreede 2001) and all of the order Ulotrichales (e.g., Guiry and Guiy 2009). The Gomontia stages of these genera are difficult to distinguish from each other in the field, which has created a lot of confusion in the past as well as taxonomic problems (e.g., Fan 1959; Wilkinson and Burrows 1972; Golubić et al. 1975; Pantazidou et al. 2006; Round 1981, p. 241). In some taxa (e.g., Acrosiphonia grandis), the Gomontia stage grows directly into a filamentous alga without formation of zoospores (Kornmann 1970). The identified Lower Cretaceous specimens are distinctly larger than their modern counterparts (e.g., Setchell and Gardner 1920, up to $150 \mu \mathrm{m}$ in width and up to $240 \mu \mathrm{m}$ in length). The larger elongated appendages might represent so-called exit tubes from which the zoospores are released (e.g., Kornmann 1959).

In most cases, the euendolithic sporophyte stage accompanies a non-boring epilithic gametophyte stage. In Eugomontia, however, both stages are euendolithic (Kornmann 1960). A further unique characteristic is that the Gomontia stage of Eugomontia is pluricellular; in all others it is unicellular. Therefore, the observed Gomontia stages could belong to the euendolithic Bacinella irregularis Radoičić. In this case, the observed large sporophyte dimensions would fit the cell diameters of the euendolithic Bacinella which are distinctly larger than, as for example the modern Eugomontia (Kornmann 1960, thickness about $6 \mu \mathrm{m}$ ). 


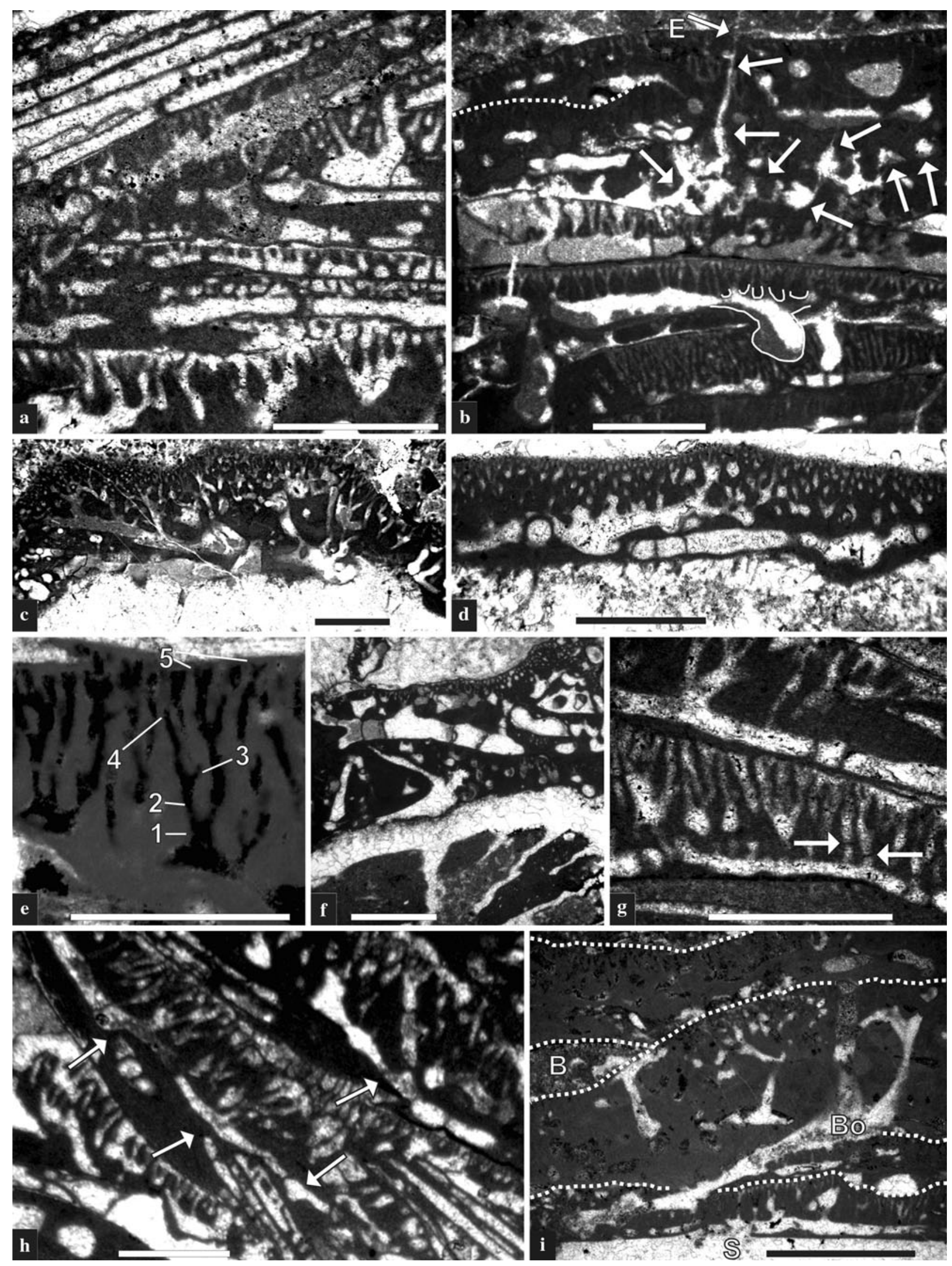




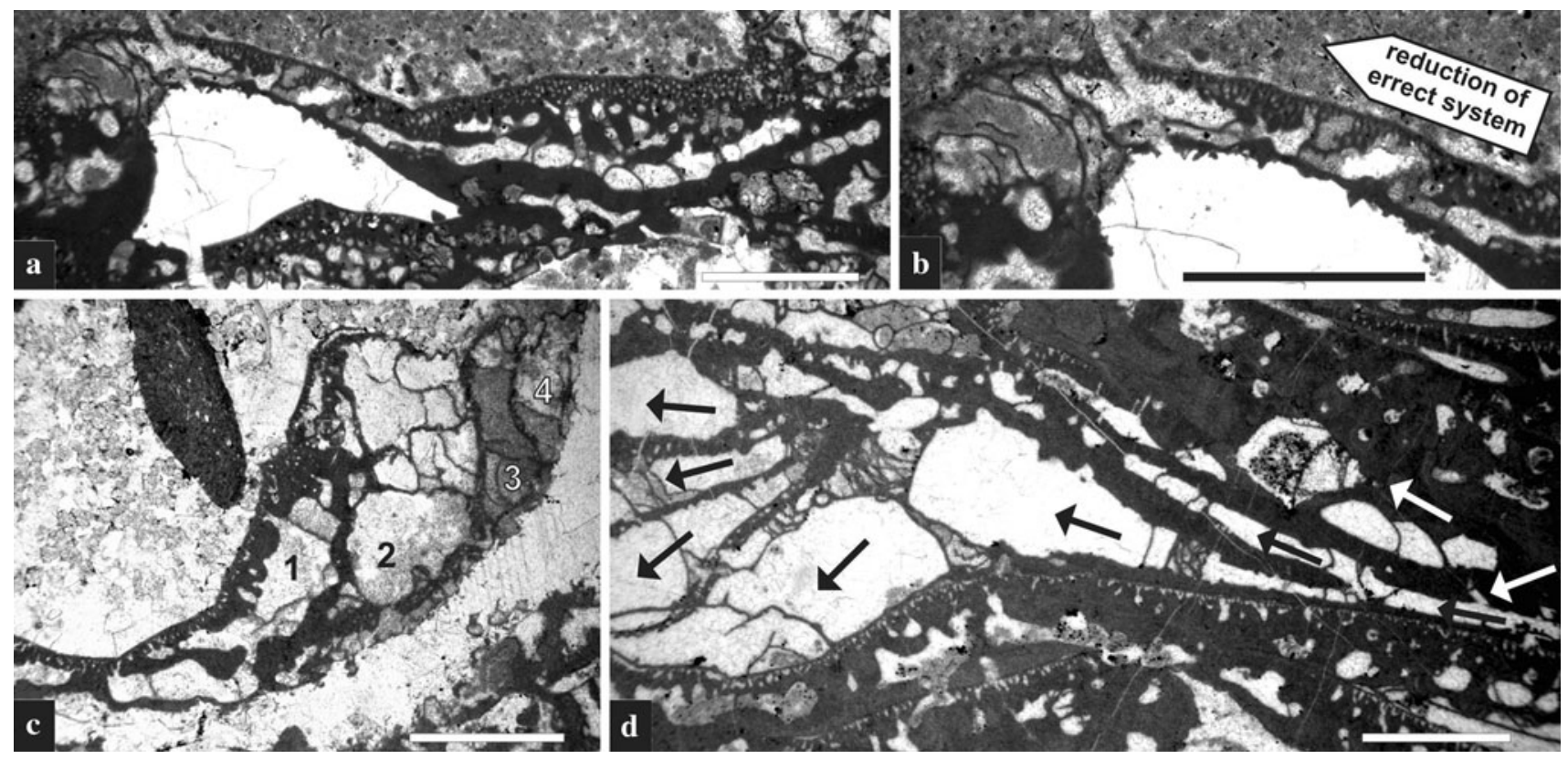

Fig. 8 Irregular vesicular final stage of Lithocodium aggregatum Elliott from the Lower Aptian of the western Maestrat Basin. a Oblique section of two superimposed crusts; external upper crust with irregular vesicular final stage. b Detail from a showing development of large sparite- to microsparite-filled irregular vesicular pseudocells arising from tubular swollen prostrate filaments along with the successive reduction of the erect filament system. c Oblique section showing

Based on the branching appendages revealing conspicuous similarities to the erect filaments of Lithocodium aggregatum, the sporophyte stages are here tentatively ascribed to the genus Lithocodium. The illustrated Gomontia stages are from the Tithonian of Austria (Fig. 5c), the Valanginian of Serbia (Fig. 5i), and the Lower Aptian of the western Maestrat Basin of Spain (Fig. 5a, b, d, e, g).

The ichnotaxon Cavernula Radtke, which refers to the sporophyte stage of these euendolithic chlorophytes (Radtke 1991; Schmidt 1992; Glaub 1994), has been known since the Carboniferous (Wisshak et al. 2008, 20-35 $\mu \mathrm{m}$ in width, 30-70 $\mu \mathrm{m}$ in length). The complex boring pattern of Eugomontia Kornmann is related to the ichnotaxon Rhopalia Radtke (Radtke 1991; Golubić and Radtke 2008). In our case, the sack-like sporophyts are clearly delineated within the boring, sometimes with observable walls towards or inside the appendages, thus, excluding an ichnotaxonomical approach.

\section{Chasmoendolithic basal stage (Fig. 6a-d, f-g)}

In our material, these cellular structures completely fill existing cavities (e.g., Gastrochaeonolites ichnogenus, Fig. 6b) or the interseptal spaces of the corals (Fig. 6c, d, f, $\mathrm{g}$ ); whether they also fill borings/etchings possibly produced by Lithocodium itself is unknown. It is noteworthy several superimposed series of irregular final cells evolving from prostrate filaments (1-4). d Oblique crust section showing development of several irregular attached terminal pseudocell-systems rising from swollen tubular prostrate filaments. Arrows also indicate direction of growth/creeping. Scale bars $1.0 \mathrm{~mm}$ for a-d. Thin sections: a-b CAL$6 \mathrm{~V}, \mathbf{c} \mathrm{H} 0-8 \mathrm{~V}, \mathbf{d} \mathrm{H} 0-7 \mathrm{~V}$

that these structures are absent on smooth unsculptured substrate surfaces (e.g., rudistid shells, some stromatoporoids, Figs. 3c, 4f). This could be an indication of a no-boring ability. In the cases where the void is narrower, only horizontal to oblique transverse walls occur (Fig. 6d, left) and the substrate surface shows a thin micritic lining. In broader voids, a house-of-cards-like system composed of complete (from one side to the other) and incomplete (forming smaller cells within the void) partitions evolves (Fig. 6c, d, right). This character is a clear expression of the mechanical properties of these structures depending on the width of the spaces they occupy. In internally sculptured narrow spaces (e.g., interseptal spaces of microsolenids), the initial part of Lithocodium directly adjusts to the available space with a comparable thick micritic lining towards the sidewalls (Fig. 6g). In that manner, a comparably large penetration depth can be achieved. An exceptional case is what we here refer to as the pseudo-chasmoendolithic stage occurring in a boring of a lithophagid bivalve (Fig. 6b). Here, Lithocodium attached at one side of the boring at a time when this was horizontally oriented (geopetal attaching). The remaining available space was then completely filled with large vesicles of the aberrant final stage (see below). The bioclasts with borings completely filled by Lithocodium were totally encrusted afterwards by different Lithocodium crusts, and its older parts became totally 
micritized. Within the whole encrusted crust-bioclasts complex, the filled borings appear as representing the chasmoendolithic basal stage described above.

Remarks This stage has already been commented on several times in the literature, for example:

- Banner et al. (1990, p. 30, pl. 5/2): ....."medullary filaments of encrusting Lithocodium may fill these borings so closely that the impressions may be gained, erroneously, that the encrusting alga had, itself, created the borings".

- Neuweiler and Reitner (1992, pl. 3/2): "partly calcified single filament of Lithocodium. Cells arranged in rows as smallest structural element of Lithocodium" (translated from German).

- Kolodzjei (1997): "In the places where it (remark: Lithocodium) has grown into the interseptal space of the coral skeleton it sometimes shows "bacinellimorph" structures".

- Daoud et al. (2004, pl. 2/4): "Rudist skeleton perforated by Troglotella incrustans Wernli and Fookes hosted by Bacinella-Lithocodium".

- Matyszkiewicz and Slomka (2004, fig. 3/b, c): "Bacinella partly fills voids between the septa in a scleractinian coral".

- Schlagintweit (2008, fig. 5): "Infilling structures and microborings with Bacinella-Lithocodium".

These examples show that these cellular structures occurring in skeletal voids were ascribed to both Lithocodium and Bacinella. Segonzac and Marin (1972) and some other authors (e.g., Luperto Sinni 1979) regarded Bacinella as corresponding to the basal part of Lithocodium, here interpreted as a cellular filling stage of Lithocodium aggregatum. The prostrate filaments probably could not spread over sculptured surfaces, thus, first creating a plane surface for attachment by filling the substrate voids with a chasmoendolithic cellular meshwork. Only in cases where the voids are wide enough can the heterotrichale filaments be observed inside (Fig. 6e). The preservation of these vesicular basal structures can be considered as an indication for the rather rapid lithification of the crusts and comparable good mechanical properties; otherwise they might have been destroyed by compactional processes. It is noteworthy that in contrast to the irregular cellular final stage (see paragraph later in the text), no calcimicrobes were observed within the vesicles of the basal stage.

Epilithic filamentous stage (Figs. 3a-f, 4a, c, f, g, 7a-i, 14a pars)

The epilithic crustose thalli are seldom single-layered, for example in cases where these alternate with other crustose organisms such as encrusting foraminifera (Fig. 3d) or lam-
Table 3 Dimensional data of Lithocodium aggregatum Elliott from the Lower Aptian of the western Maestrat Basin (thicknesses in mm)

\begin{tabular}{|c|c|c|c|c|c|}
\hline No. & $\begin{array}{l}\text { Thickness } \\
\text { of crust }\end{array}$ & $\begin{array}{l}\text { Thickness } \\
\text { prostrate } \\
\text { system }\end{array}$ & $\begin{array}{l}\text { Thickness } \\
\text { erect } \\
\text { system }\end{array}$ & $n$ & $\begin{array}{l}\text { Thin } \\
\text { section }\end{array}$ \\
\hline 1. & 0.08 & 0.032 & 0.036 & 1 & $\mathrm{PO}-4 \mathrm{~V}$ \\
\hline 2. & 0.18 & 0.032 & 0.120 & 2 & \\
\hline 3. & 0.36 & 0.145 & 0.170 & 3 & \\
\hline 4. & 0.40 & 0.145 & 0.20 & 3 & \\
\hline 5. & 0.07 & 0.03 & 0.03 & 1 & \\
\hline 6. & 0.26 & 0.052 & 0.20 & 3 & \\
\hline 7. & 0.32 & 0.1 & 0.20 & 2 & H0-6V \\
\hline 8. & 0.25 & 0.05 & 0.19 & 3 & \\
\hline 9. & 0.16 & 0.066 & 0.07 & 1 & $\mathrm{PO}-4 \mathrm{~V}$ \\
\hline 10. & 0.35 & 0.14 & 0.18 & 2 & CAL-7H \\
\hline 11. & 0.22 & 0.04 & 0.14 & 3 & \\
\hline 12. & 0.30 & 0.065 & 0.20 & 4 & $\mathrm{H} 0-16 \mathrm{~V}$ \\
\hline 13. & 0.36 & 0.12 & 0.20 & 3 & \\
\hline 14. & 0.36 & 0.09 & 0.25 & 5 & CAL-3V \\
\hline 15. & 0.45 & 0.08 & 0.26 & 3 & DE-3H \\
\hline 16. & 0.65 & 0.12 & 0.36 & 5 & CUB-1 \\
\hline 17. & 0.26 & 0.09 & 0.16 & 3 & SE-5H \\
\hline 18. & 0.28 & 0.03 & 0.26 & 4 & CAL-8V \\
\hline 19. & 0.37 & 0.09 & 0.26 & 3 & DE-5H \\
\hline 20. & 0.42 & 0.14 & 0.22 & 3 & CC-4V \\
\hline Min. & 0.08 & 0.03 & 0.03 & 1 & \\
\hline Max. & 0.65 & 0.145 & 0.36 & 5 & \\
\hline
\end{tabular}

$n=$ max. number of filament layers/orders in the erect system

inar stromatoporoids (Fig. 4f). Mostly, there are several superimposed crust layers forming thick algal masses that can totally surround the bioclastic substrate (Fig. 3b, e). The image section shown in Fig. 7a, for instance, is a detail from a succession of up to 40 superimposed (mostly thin) crust layers. The thickness of individual crust layers is mostly between 0.2 and $0.4 \mathrm{~mm}$ (see Table 3). Segonzac and Marin (1972, p. 332) indicate thicknesses of 1 to $3 \mathrm{~cm}$ for the superimposed crusts, and a maximum of $0.45 \mathrm{~mm}$ for a single layer; Elliott (1956, p. 331) indicates "commonly $0.25 \mathrm{~mm}$ ". In cases of thick crust masses, the sparitefilled filaments can only be observed in the outermost layers (Fig. 3e); the older layers are completely micritized. The filamentous system is only recognizable in a slightly brighter color (dark grey instead of black) (Figs. 3f, 6a, 11e).

The thalli are differentiated into a prostrate basal part (or system) and an erect branching part (or system). The prostrate system is not directly attached to the basal substrate (e.g., coral skeleton, rudistid shell, or underlying Lithocodium crust) but separated from it by a thin micritic sheet (e.g., Fig. 7g). Transverse cell walls (septae) with thickness 
of $\sim 8-15 \mu \mathrm{m}$ occur at irregular distances forming uniseriate cells. Sometimes the filaments are constricted at the plane of septation giving rise to barrel-shaped uniseriate cells. These cells may also show a slight increase in diameter towards the growth direction, giving them the shape of a club. Especially comparable, thin prostrate filaments appear more or less without constrictions and without transverse septae (?lost as a result of recrystallization). This type was compared by Segonzac and Marin (1972, p. 335) with a garden hose ("tuyau d'arrosage"). In oblique sections, it can be seen that the prostrate filaments are branchings, often at acute angles (Figs. $4 \mathrm{~g}, 7 \mathrm{~d}, \mathrm{~h}$ ) but also at right angles (Fig. 8a). With successive branching in the growth direction, the prostrate system radiates and spreads over the substrate. In sections transverse to the filament creeping direction, the individual prostrate filaments appear as irregular-ovoid spar-filled spaces separated from each other by a micritic tissue (Fig. 3e).

From the prostrate system, erect branching filaments rise upwards with several filaments originating from each cell. The erect filaments often start from short tapering protuberances of the prostrate filaments, whereas the lower part is more or less smooth. The shape of the filaments and their branching pattern is very variable, from swollen to cylindrical, parallel (pallisade-like) or radiating. In oblique sections, the branching prostrate filaments can be misinterpreted as representing the first-order thick filaments of the erect system (Figs. 4g, 7d, f, h). However, even the first-order erect filaments are distinctly thinner than the prostrate filaments. They may bifurcate, trifurcate or quadrifurcate (Fig. 7a, e, g). Altogether, a maximum of five orders of filaments were observed (Fig. 7e). With successive branching, the diameters diminish slightly; the greatest difference in thickness is between the first- and secondorder filaments. In very thin crusts, the erect system may become greatly reduced; in extreme cases to only one layer of erect filaments (Figs. 3a, 7a). The outermost filaments are closed to the exterior, terminating in a thin sheet (= terminal sheet of Banner et al. 1990, p. 28) (e.g., Fig. 3e). Septation is irregular and is often not so easily recognizable as in the prostrate filaments (possibly due to recrystallization processes) (e.g., Figs. 4a, c, 7g).

Remarks With the new interpretation, the couplet of medullary and cortical filaments is replaced by prostrate and erect filaments. The branching of the prostrate filaments (formerly medullary or subdermal filaments) was already recognized by Banner et al. (1990, p. 28, "they ramify diversely...."). In some recent works, the septate filaments have occasionally been interpreted as "Bacinella" threads within Lithocodium. The fact that not only the crust-parallel filaments (= medullar filaments of Elliott 1956; Banner et al. 1990; Segonzac and Marin 1972) but also the erect filaments are septate was not recognized by
Segonzac and Marin (1972), but in discussing affinities to ulotrichalean algae, and especially mentioning the genus Gomontia, they came very close to our interpretation.

The typical micritization of the older crusts was also noted by Elliott (1956, p. 331, "recrystallization has affected more inner layers than outer ones") or later by Koch et al. (2002, p. 84, ..."the oldest parts of the organism became impregnated by micritic Mg-calcite"). The dimly recognizable microstructures of the micritized inner crusts were obviously overlooked by Banner et al. (1990, p. 24) or perhaps they were not recognizable in their material, as they stated that only "the terminal zone of growth developed cortical structures".

\section{Vesicular terminal stage (Fig. 8a-d)}

Large, usually completely sparite-filled cells (vesicular textures of Maurin et al. 1985) occur in the outermost crust zones, evolving directly from the irregularly swollen cylindrical prostrate filaments (e.g., Fig. 8b). The giant cells can attain a length of up to $1.7 \mathrm{~mm}$ and a width or height of $\sim 0.8 \mathrm{~mm}$. These are different from the basal cellular fabrics as they possess larger sizes, lack the intermingling with micritic patches, and sometimes exhibit a rounded bent side facing upwards with short parallel protruding partitions/ filaments. This last characteristic seems to correspond to the endings of the terminal filaments of a nearly completely reduced erect system. The continuous reduction of the erect system along with the irregular broadening of the prostrate filaments can be seen in the specimen shown in Fig. 8a, b. Furthermore, oblique sections show that each of the radiating prostrate filaments undergoes this evolution of giant terminal cells, forming a large irregular meshwork (Fig. 8c, d). In some cases, erect bushy or tubiferous filaments of assumed calcimicrobial origin are observable inside some vesicles (see Fig. 16). The same bushy calcimicrobes were occasionally also observed within thicker prostrate filaments of the outer crust zone (Fig. 16g).

Remarks As already remarked previously, we do not know of a modern algal taxon that shows the morphological features of Lithocodium aggregatum Elliott. Particularly, this is the case for the irregular giant terminal vesicular cell meshwork as the terminal development of the prostrate system along with the reduction of the erect system. It can be assumed that this vesicular stage was previously often recognized as Bacinella irregularis Radoičić. It is unknown whether the observed calcimicrobes inside these cells functioned as symbionts (cyanosymbionts) during the lifetime of Lithocodium or occupied them post-mortem. As this terminal stage was always observed at the outermost crust, a special morphological adaptation in order to host these probably phototrophic calcimicrobes can be hypothesized. 
Comparisons Discussing the validity of other Lithocodium species, L. regularis Johnson (invalidly described as an alga, see Johnson 1969), L. morikawai Endo and L. japonicum Endo, Banner et al. (1990, p. 28) concluded that the genus "may subjectively be monotypic", a view also accepted by Schmid and Leinfelder (1996). In these two works, both species established from the Upper Jurassic of Japan by Endo (1961) were considered to be identical to the Lower Cretaceous type-species Lithocodium aggregatum, and thus regarded as junior synonyms. The "presence of well-marked sporangia" in Lithocodium japonicum was accentuated by Endo (1961, p. 64) as a species character. In any case, it seems to be a strange procedure, if not taxonomically incorrect to create a new species for a fertile stage of another taxon, L. aggregatum + sporangia $=$ L. japonicum. These sporangia, however, were correctly identified by Schmid and Leinfelder (1996) as the chambers of the cryptobiotic foraminifer Troglotella incrustans Wernli and Fookes, which can be arranged serially or irregularly within the so-called basal chambers just above the encrusted substrate (Fig. 9b, d, f). Therefore, the species L. japonicum is here interpreted as belonging to the "Lithocodium aggregatum"-Troglotella incrustans consortium as described by Schmid and Leinfelder (1996). It must be noted, however, that the chambers of Troglotella incrustans are not recognizable in all figurations of "Lithocodium japonicum", only in pl. 5/3 and pl. 15/2 of Endo (1961). Lithocodium morikawai, the second species described by Endo (1961, p. 65) should be distinguished from L. japonicum and L. aggregatum by the "presence of secondary and tertiary filaments" although in the remarks for L. japonicum, the well-defined differentiation between the primary and secondary filaments was also stressed by Endo. Concerning L. aggregatum, Elliott (1956) did not explicitly remark on the order of the branchings, but his figurations, though displaying low magnification, allows us to recognize at least primary and secondary filaments. The material from the Lower Cretaceous of the Maestrat Basin allows the recognition of up to five orders of filament layers (cf. Banner et al. 1990, p. 28, "usually three or more"). Therefore, L. morikawai is here regarded as a junior synonym of L. aggregatum; the septate erect filaments are recognizable in plate 12, Fig. 4 of Endo (1961), the prostrate system for example in pl. 12, Figs. 1, 3.

The Late Jurassic specimens, illustrated by Schmid and Leinfelder (1996), do not allow recognition of a heterotrichal thallus morphology with septate prostrate and erectbranching filaments of Lithocodium aggregatum as redescribed here. The distinctly reduced or even non-branching aspect of the filaments, their obvious lack of septation and occurrence of roughly hemispherical basal cavities separated from each other (e.g., Schmid and Leinfelder 1996, pl. 1/4 or reconstructions text, figs. 7,8 ) (e.g., Fig. 9c) are totally different from the heterotrichal chlorophyte Lithocodium aggregatum Elliott as described in the present paper. Therefore, the Upper Jurassic representatives illustrated by Schmid and Leinfelder (1996) are considered as belonging to another (probably new) taxon, which could be identical to the forms reported from the Upper Triassic (Fig. 9a). In fact, besides the lack of epilithic septate filaments, the often mono-layered crusts reported from the Late Triassic to Late Jurassic are characterized by a more or less regular arrangement of spar-filled large basal cavities (e.g., SenowbariDaryan 1980, 1984, pl. 10/7; Wurm 1982; Kuss 1983; Stanton and Flügel 1989, pl. 29/5a; Schmid and Leinfelder 1996). In most cases, these basal cavities are empty; Kuss (1983, pl. 17/7) figured microcrystalline irregular partitions inside; in the Upper Jurassic, as already emphasized, these cavities are often occupied with the tests of the cryptobiotic foraminifer Troglotella incrustans Wernli and Fookes. In addition, the Triassic crust layers are distinctly thicker, 0.95-1.75 $\mathrm{mm}$ according to Senowbari-Daryan (1980) (see Table 3 for comparison). Last but not least, the specimens described by Schmid and Leinfelder (1996) from the Upper Jurassic of Portugal may trap siliciclastic particles (Fig. 9e) and derive from shallow inner ramp settings, whereas our material from the Lower Aptian is interpreted to have flourished in deeper-water environments (see Bover-Arnal 2010).

Stratigraphy The stratigraphic range of Lithocodium aggregatum Elliott known so far is (Oxfordian?)TithonianConiacian (see synonymy heading). Due to rare records of Lithocodium aggregatum Elliott in the Late Cretaceous (e.g., Höfling 1985; Steuber 2001: Middle Coniacian of Northern Calcareous Alps), this interval might not necessarily correspond to its total stratigraphic range. As already discussed, the Triassic illustrations of Lithocodium aggregatum (or Bacinella irregularis) in the literature (e.g., Senowbari-Daryan 1984; own data) cannot be ascribed to septate ulotrichalean algae; these organisms and structures need revision.

\section{Comments on Pseudolithocodium carpathicum Mišík}

The microencruster incertae sedis Pseudolithocodium carpathicum was described by Mišík (1979) from the Upper Jurassic of the Western Carpathians. It is characterized by "two types of tissue", consisting of an older stage with larger irregular to oval cells and a younger part consisting of "rarely bifurcating tiny tubes" (or alveoles) more or less perpendicular to the thallus surface (Fig. 10a, e). In contrast to the genus Lithocodium Elliott, Mišík (1979, p. 709) stated that "the tubes of the cortical layer are densely packed, not submerged in micrite". In the original diagnosis, Pseudolithocodium was characterized as an encrusting alga. Besides thalli fixed to hard substrates (e.g., corals, 

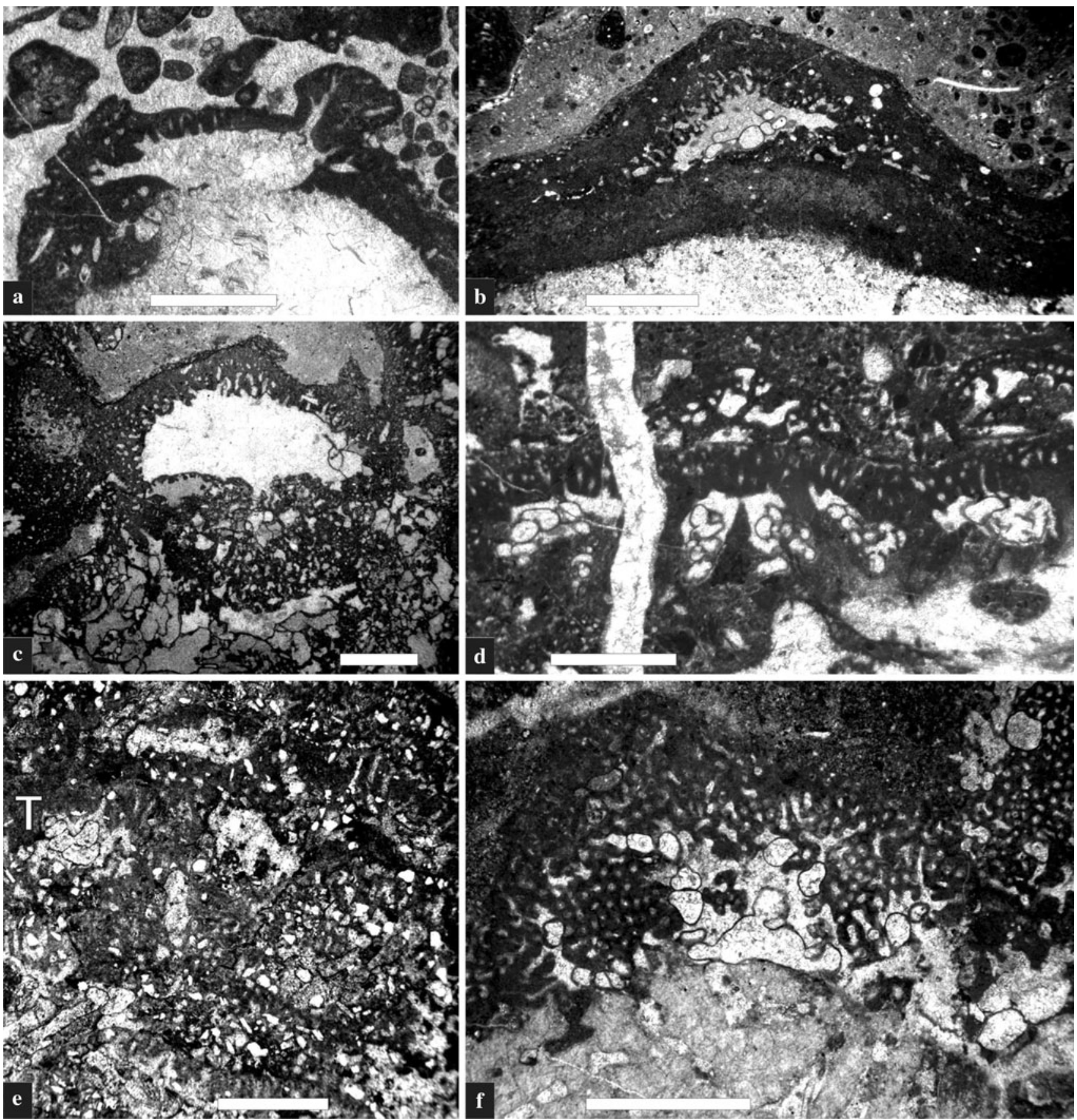

Fig. 9 Enigmatic microencruster incertae sedis formerly ascribed to Lithocodium aggregatum Elliott from the Upper Triassic of Austria (a), the Upper Jurassic of Austria (b-d, f) and Portugal (e). a Specimen fixed to a substrate showing a large sparite-filled basal cavity/"chamber" (size: $\sim 1.4 \times 0.4 \mathrm{~mm}$ ), Norian-Rhaetian Dachstein Limestone, Mount Loser, Austria. b Specimen switched between microbial crusts; large basal cavity/chamber with cryptobiotic foraminifer Troglotella incrustans Wernli and Fookes, Upper Tithonian (?Lower Berriasian), Mount Dietrichshorn, Austria. c Specimen with large empty basal cavity/chamber (size: almost $3 \times \sim 1 \mathrm{~mm}$ ); below vesicular structures,

stromatoporoids), however, free irregular-shaped specimens may also be present within the surrounding matrix. In these forms, the differentation of an older and younger part
Upper Tithonian (?Lower Berriasian), Mount Dietrichshorn, Austria. d Several separated chambers each with cryptobiotic foraminifer Troglotella incrustans Wernli and Fookes inside, Upper Tithonian, Mount Trisselwand, Austria. e Several superimposed crusts with trapped siliciclastics and Troglotella incrustans Wernli and Fookes (T), Kimmeridgian of Lusitanian Basin, Portugal. f Specimen fixed to a stromatoporoid skeleton with Troglotella incrustans Wernli and Fookes inside cavities/chambers, Upper Tithonian (?Lower Berriasian), Mount Dietrichshorn, Austria. Scale bars $1 \mathrm{~mm}$ for a-f. Thin sections: a Los-1, b-c, f Die-170, e AB-I-7 (leg. Martin Nose)

is not possible given that the "younger" alveolar layer surrounds the irregular ovoid cells of the "older" stage (Fig. 10c, d). In the Upper Jurassic of the Northern Calcareous 
Alps of Austria, Pseudolithocodium occurs often associated with the alga incertae sedis Thaumatoporella parvovesiculifera (Raineri) (Schlagintweit and Ebli 1998, pl. 10/4) (Fig. 10a, b). In the cases where Thaumatoporella shows internal cell-like compartments, both have a similar appearance (see also Cherchi and Schroeder 2005). Thaumatoporella shows an outer wall of more or less constant diameter and strictly parallel and more or less isodiametric alveoles/ pores (Fig. 10b); in Pseudolithocodium these are more irregular embedded in micrite which accounts for a distinctly darker appearance and may show branching in addition. It is worth to mention that Thaumatoporella parvovesiculifera was originally described with cylindrical thalli from the Upper Cretaceous of Italy (Raineri 1922; De Castro 2002); later a greater morphological variability (e.g., encrusting, nodular) was attributed to these thaumatoporellacean algae (De Castro 1990 for details).

Several authors have regarded Pseudolithocodium as a junior synonym of Lithocodium Elliott (Banner et al. 1990; Schmid 1996; Schmid and Leinfelder 1996; Koch et al. 2002). The assumption of such a synonymy has a direct consequence for the taxonomic interpretation of Pseudolithocodium (see Table 1). Senowbari-Daryan et al. (1994) remarked a possible difference at the species level, whereas others maintain the validity of both genera (Schlagintweit and Ebli 1999; Dragastan and Richter 2003). A differentiation into a prostrate basal part and an upper erect part with branching filaments giving rise to a heterotrichal thallus construction, as emended for Lithocodium Elliott, is not discernible on the original figurations. Hence, Pseudolithocodium Mišík is here regarded as a different taxon. Whether this taxon, however, can be included in the variability of those forms that we excluded from Lithocodium aggregatum Elliott, is beyond the scope of the present paper and needs further restudies of both Upper Triassic to Upper Jurassic representatives along with the original material of Mišík (1979).

\section{Comments on the type-material of Bacinella irregularis Radoičić}

First of all, it must be mentioned that the type-material of Bacinella irregularis is housed at the Geological Institute of Serbia in Belgrade, but not within a certain collection and at present unfortunately not available for re-study (pers. comm. Rajka Radoičić).

The holotype and one paratype of Bacinella irregularis are illustrated in Radoičić (1959, pl. 3/1-2). In the genus diagnosis, the interior of the crust is described as being "constructed by unregular cells of different size and form, which are filled with crystalline calcite (Remark: sparite) whereas the intercellular mass is cryptocrystalline (Remark: micrite)" (Radoičić 1959, p. 92) (Fig. 11a). In the species description the "cells" of Bacinella irregularis are further specified as being "arranged into association or into some sort of unregular series which are intermingled"; the inner structure was interpreted by Radoičić as "unclear"; along the same line, we must remind that Elliott (1956) also characterized the inner part of Lithocodium as "confused". Regarding the serial cell arrangement, detectable in the holotype specimen (Fig. $11 \mathrm{a}, \mathrm{c}$ ), we have to stress that the choice of the species name was somehow misleading. The thin microcrystalline cross-partitions within the sparite-filled "cells" were not explicitly mentioned; it can be assumed, however, that Radoičić was aware of this as otherwise the term "cell" would probably have been replaced by "filament" or "siphon". In this regard, a general resemblance of the holotype of $B$. irreg $u$ laris to L. aggregatum has been mentioned by Banner et al. (1990, p. 22), noting that the former "is distinguishable only by the more frequent occurrence... of thin walls separating the adjacent cells of particular filaments". As Banner et al. (1990) were treating Bacinella as a junior synonym of Lithocodium, they must have considered these filaments with crosswalls as "medullary filaments" sensu Elliott as these authors were considering the "cortical filaments" to be non-septate. The differentiation of the "subdermal structure" of Bacinella irregularis, as remarked in the generic diagnosis, was compared by Radoičić with "that one of the species Lithocodium aggregatum Elliott", but without further comments as to why it was obviously regarded to be different. The holotype specimen clearly allows us to recognize that the "cells" are not really disorganized, but are radiating (from right to left, Fig. 11a) and successively branching, forming a reticulate network. The direct continuity refers them to the typus of uniseriate septate branching filaments; their continuation into the final fine branching layer ("cortical zone" of Elliott) can be discerned on the left upper side of the holotype (Fig. 11a, c). The "small circular cells" described by Radoičić (1959, p. 92) within the "subdermal" "cryptocrystalline mass" are interpreted here as transverse sections of the uniseriate septate filaments. It is noteworthy that a "vague linear cell arrangement or a suggestion of septate tubes" was already remarked on by Beckmann and Beckmann (1966, p. 41). In the middle part of the holotype figuration (Fig. 11a), and also clearly visible in the studied Lower Aptian material from Spain (Fig. 11b, d), the forming of a network with anastomizing filaments can be observed. The diameter of the cells (= filament diameter) - as measured from the holotype figuration-is $0.07-0.22 \mathrm{~mm}$ (mostly around $0.15 \mathrm{~mm}$ ). The septae occur at distances from 0.15 to $0.5 \mathrm{~mm}$.

Much of the long-term confusion in the literature resulted from the fact that many authors were referring to the apparently more disorganized altered structure of the 

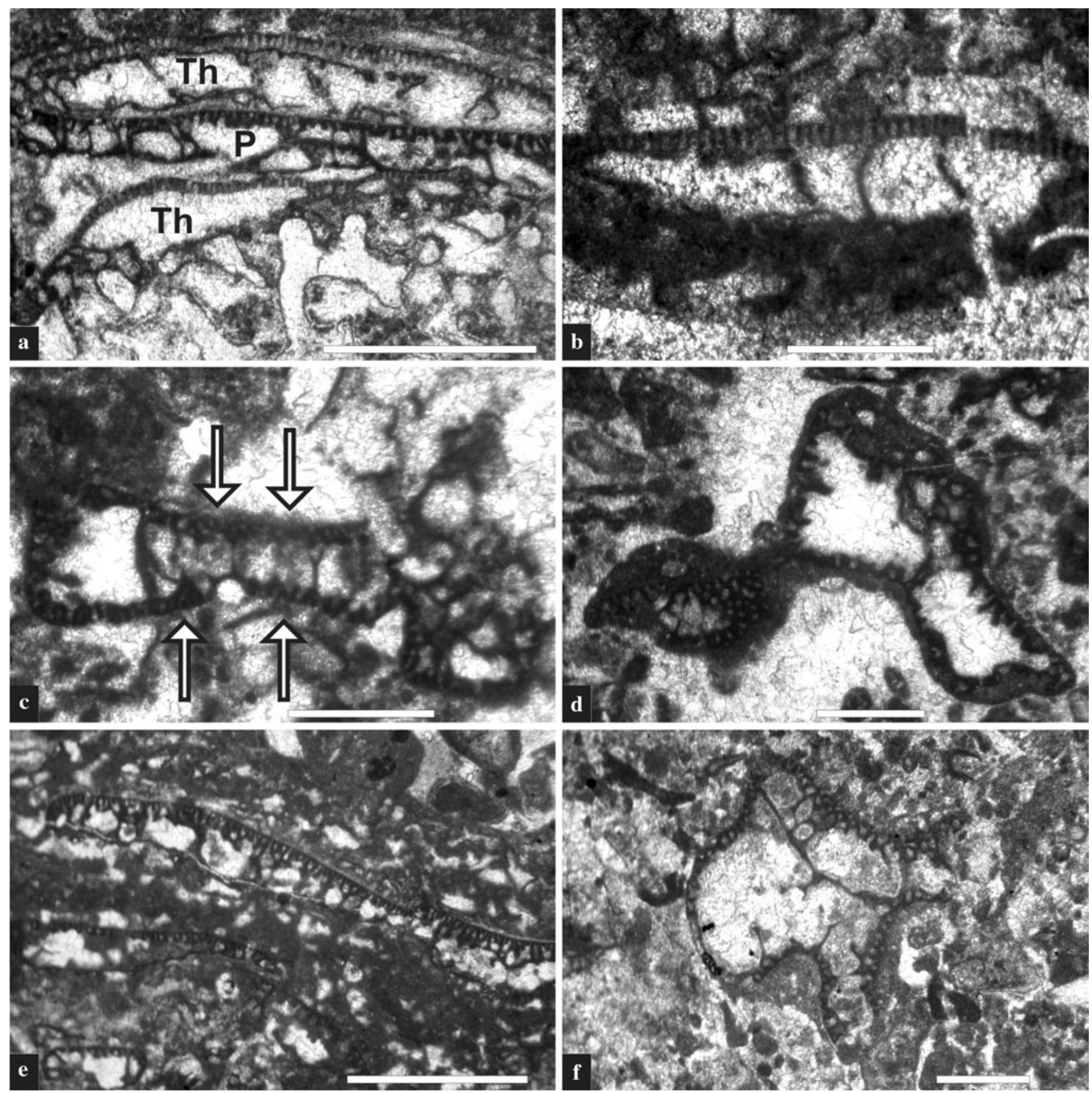

Fig. 10 Pseudolithocodium carpathicum Mišík and Thaumatoporella parvovesiculifera (Raineri) from the Upper Jurassic of the Northern Calcareous Alps of Austria. a Succession of Thaumatoporella parvovesiculifera (Raineri) (Th) and Pseudolithocodium carpathicum Mišík $(P)$ encrusting a stromatoporoid skeleton. b Encrusting thaumatoporellacean alga with thin transverse walls forming closed and partly open

paratype specimen of Bacinella irregularis, considered here as an oblique section, and transferring it furthermore to any cellular-vesicular structures without taking a closer look at the original illustration of the holotype specimen.

? Order Ulotrichales

Genus Bacinella Radoičić compartments/cells. c-d, f Free specimens of Pseudolithocodium carpathicum Mišík showing allside alveolar layer (arrows, c) and large cells with incomplete partitions (f). e Several layers of encrusting Pseudolithocodium carpathicum Miš́ík. Scale bars $1 \mathrm{~mm}$ for a, e; $0.5 \mathrm{~mm}$ for $\mathbf{b}-\mathbf{d}, \mathbf{f}$

Original diagnosis Nodular and encrusted algae whose interior is constructed by unregular cells of different size and form, which are filled with crystalline calcite, whereas the intercellular mass is cryptocrystalline. The subdermal structure is differentiated (Radoičić 1959, p. 92) 
Emended diagnosis Euendolithic, facultative cryptoendolithic alga boring into calcareous substrates. Thallus composed of uniseriate filaments basically cylindrical, barrel-shaped or irregular in shape exhibiting branching often in an opposite manner; hairs occasionally occur. Adult thalli form a complex anastomizing network inside the substrate within a zone parallel to the surface. Terminal cells with short branches (one or two layers) stretching close to the substrate surface without penetrating it. Cell- and crosswalls thin, of microcrystalline calcite.

Order: Ulotrichales

Family: ?

Genus: Bacinella Radoičić 1959

Bacinella irregularis Radoičić 1959

(Figures 11a-h, 12e-g)

Synonymy The cellular-vesicular structures associated with Lithocodium aggregatum Elliott or not, are different from the filamentous-septate and branching alga figured by Radoičić (1959) as the holotype specimen. Consequently, as interpreted herein, the synonymy list becomes drastically reduced.

*1959 Bacinella irregularis nov. gen., nov. sp. Radoičić, pl. 3/1-2

1987 Bacinella irregularis Radoičić - Reitner, pl. 21/1

Description Euendolithic alga with a thallus consisting of septate uniseriate filaments. The alga bores into calcareous bioclasts (here: thalli of Lithocodium aggregatum, e.g., Fig. 11e) or stretches cryptobiotically into existing skeletal structures of corals or calcareous sponges (Fig. 12g). The boring activity of Bacinella penetrating crusts of Lithocodium is well discernible where embryos of the former were entering borings of lithophagid bivalves that were affecting both the bioclastic substrate and the superimposed crusts of Lithocodium (Fig. 11e). In this case, the juvenile part is more or less straight (nearly $2 \mathrm{~mm}$ long) with some short simple lateral branches penetrating several crust layers. In a zone parallel to the crust surface, the filament ramifies, stretching in various directions (about $5 \mathrm{~mm}$ in lateral extent). Branches may occur either upon two outgrowths of the mother cell or just juxtaposed at its rounded to flat tip. The filaments, however, not only show successive branching but also anastomization, forming bridges between the radiating filaments (Fig. $11 \mathrm{~b}, \mathrm{~d}, \mathrm{e}$ ). Within the ramifying part, long thin hairs are sometimes observable (Fig. 11e). At their proximal parts, they are up to $40 \mu \mathrm{m}$ in diameter, then taper in the direction of growth. The cross-walls delineating individual cells occur at irregular distances. Often, however, they are rather close-set (width equaling more or less the length) giving rise to a barrel-shaped appearance (Fig. 11g, h). Rarely, a cross-shaped branching pattern with a "four-armed central cell" sensu Nielsen (1987) can be observed (Fig. 12e). More elongated cells may also show bending. A slight constriction is often present at the boundary between two adjacent cells.

Remarks First of all, it must be stressed that with its crust-parallel growth of branching uniseriate chambers from which short end branches emerge, Bacinella is close to Lithocodium which is epilithic crust-forming with a microcrystalline common thallus sheath enclosing the filaments. Bacinella instead is interpreted as a euendolithic taxon without an enclosing thallus sheath, best discernible when it appears as cryptoendolith within the interseptal spaces of microsolenids or calcareous sponges (Fig. 12f, g); within the dark micritic Lithocodium crusts this feature becomes masked. From those specimens that bore the substrate/crust from outside or inside (entrance being gained via borings produced by lithophagids post-dating the crust formation), it is evident that Bacinella bored through several superimposed thalli of Lithocodium before producing a ramifying and anastomizing network parallel to the surface. Obviously the specimens tried to reach the upper crust from the bored basal substrates in a direct way: a behavior possibly linked to phototaxis/geotaxis. In a very simplified way, one could characterize Bacinella as a more irregular and purely euendolithic stage of Lithocodium; we interpret these different features as characterizing two different genera, not indicating synonymy between Bacinella and Lithocodium.

In an unpublished PhD thesis, Scholz (1979, p. 26) drew the conclusion that Lithocodium aggregatum represents a crust produced by algae and Bacinella irregularis the boring pattern of the same alga: an interpretation close to our view. Some authors have already mentioned the "boring potential" of the Bacinella/Lithocodium organism (e.g., Maurin et al. 1985; Neuweiler and Reitner 1992); others deny such an ability (Banner et al. 1990). In the material we studied, the substrate (mostly coral rubble) was already intensely bored by endolithic sponges and Bacinella irregularis before becoming completely encrusted by Lithocodium crusts. In our interpretation, Bacinella can be well ascribed to the destroyer guild, whereas Lithocodium aggregatum Elliott can be included in the binder guild (Fagerstrom 1987; Grötsch et al. 1994).

As a consequence of our results, the microcrystalline cellular structures or meshworks from Triassic and younger strata, which have commonly been referred to as Bacinella irregularis by many previous authors (e.g., Senowbari-Daryan 1984; Schmid and Leinfelder 1996), need revision. These filamentous microfabrics often occur in well-sorted pack- to grainstone textures where they bind and trap small bioclasts and peloids, indicating shallow-water settings. Such microfabrics were formerly also termed "bacinellid", "bacinelloid", "bacinellimorph" structures or just "Bacinella threads" (Maurin et al. 1985; Neuweiler and Reitner 


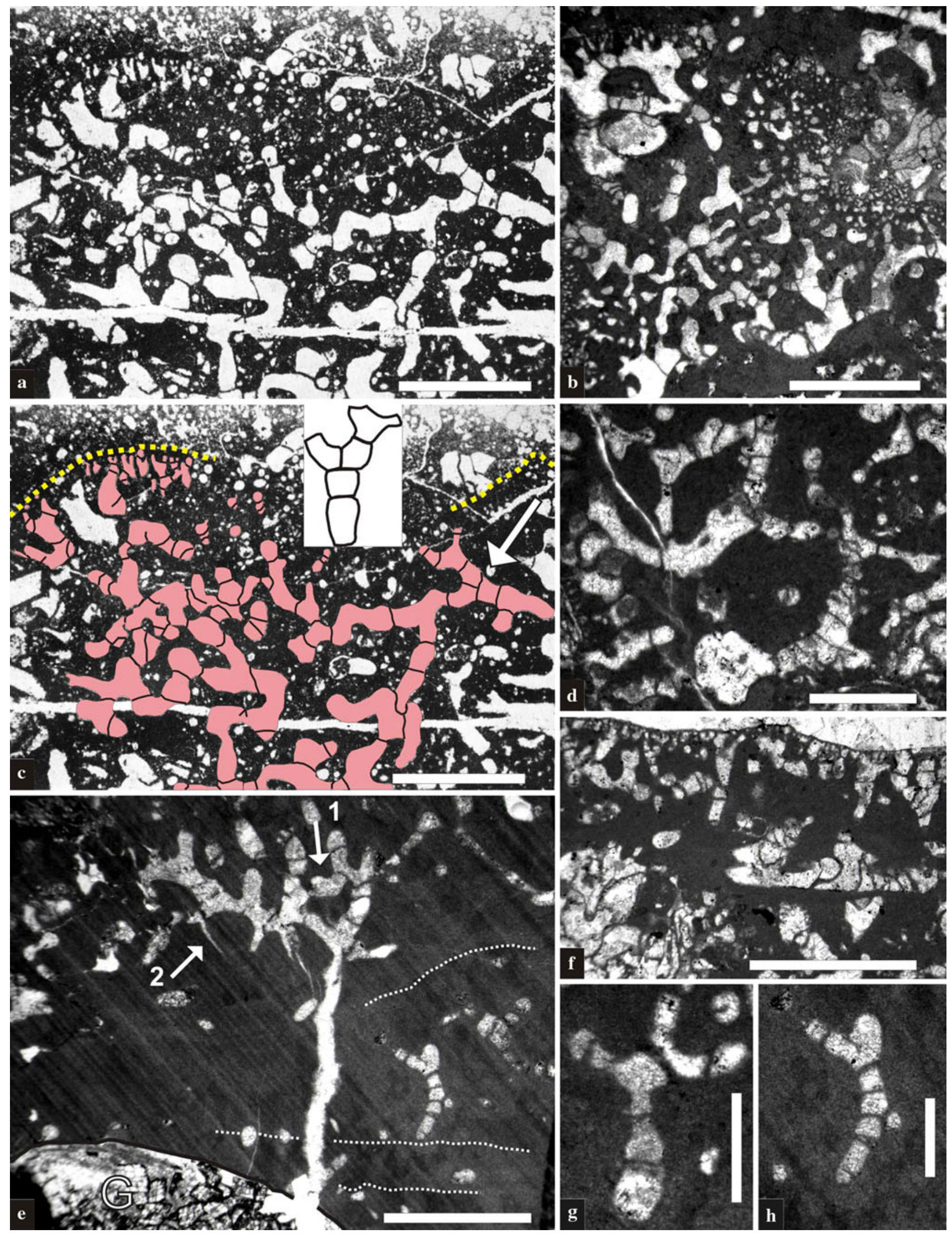


Fig. 11 Bacinella irregularis Radoičić from the Barremian-Aptian of Bosnia (a, c) and the Lower Aptian of the western Maestrat Basin (b, d-h). a, c Holotype specimen (from Radoičić 1959, pl. 3/1). In c, the euendolithic system of septate branching and also partly anastomizing filaments are colored to aid comprehension. Note the rather close set of cross-partitions giving rise to roughly cylindrical to barrel-shaped uniseriate cells. b, d, f System of branching and anastomizing uniseriate cellular filaments; note the different appearance of the terminal branching system towards the crust surface in comparison to Lithocodium. e Specimen boring through several superimposed and intensely micritized crusts of Lithocodium aggregatum Elliott (partly shown by the white dashed lines). Entry happened through a macroboring of Gastrochaenolites ichnosp. $(G)$. Boring first straight, then in the upper part ramifying (branching, anastomizing, arrow 1) in a crust-parallel zone; note fine hair-like lateral protrusion (arrow 2). The branching part is directly comparable to the holotype specimen (a). $\mathbf{g}, \mathbf{h}$ Detailed views showing the cylindrical to barrel-shaped uniseriate cells. Scale bars $1.0 \mathrm{~mm}$ for $\mathbf{a}-\mathbf{c}, \mathbf{e}-\mathbf{f} ; 0.5 \mathrm{~mm}$ for $\mathbf{d}, 0.3 \mathrm{~mm}$ for $\mathbf{h}-\mathbf{i}$. Thin sections: b CAL-5V, d H0-17V, e, g, h DE-5H, f H0-15V

1992; Schmid and Leinfelder 1996; Koch et al. 2002) (Fig. 13). Filamentous fabrics forming grain-to-grain bridges are also known from modern subtidal environments where they were neutrally described as "filamentous fabrics", but compared with Bacinella (Hillgärtner et al. 2001). They are most likely "microbial" in origin (Maurin et al. 1985; Camoin and Maurin 1988), i.e., microbial mats (see Riding 2000). Somehow similar structures are the so-called cuspate and plumose microbialitic structures reported from Archean stromatolites (Sumner 1997). The bacinelloid fabrics, however, lack the vertical oriented supports of these structures.

These biosedimentary structures cannot be termed Bacinella irregularis any longer; they should rather be addressed simply as vesicular or cellular fabrics. The species Bacinella bicellularis Sadati and Bacinella ordinata Pantic cannot be referred to Bacinella or Lithocodium and hence are in need of taxonomical revision. The Cenomanian Bacinella? sterni Radoičić was already revised to Radoicicinellopsis sterni (Radoičić) by Banner et al. (1990). The factors accounting for the often observable cooccurrence of both micritic Lithocodium-type and vesicular Bacinella-type crusts on the one side and the "monotypic" dominance of only one type on the other side, is so far

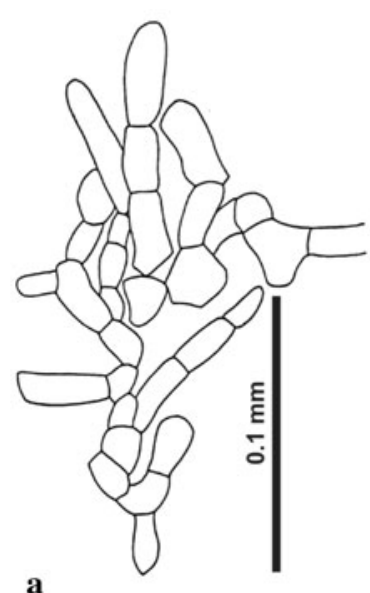

a

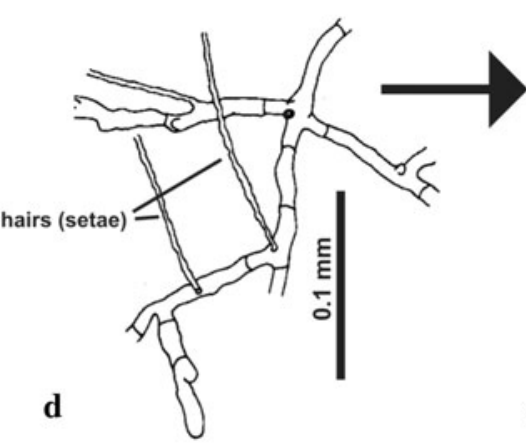

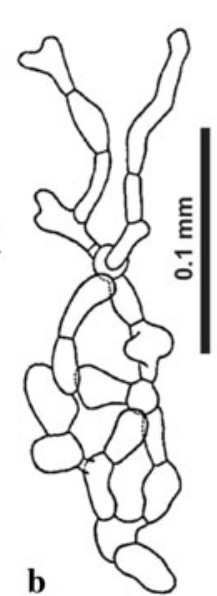

c

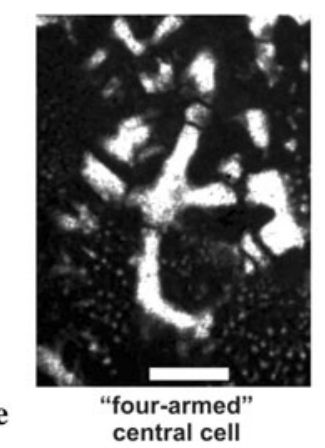

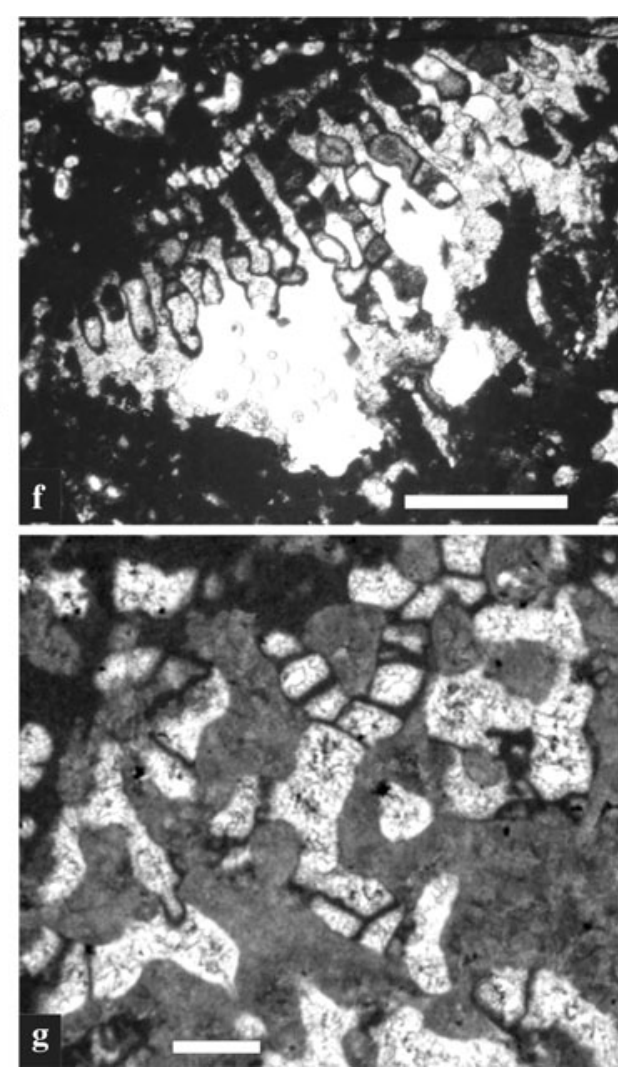

Fig. 12 Modern euendolithic chlorophyte algae (a-d) that can be compared morphologically to Bacinella irregularis Radoičić (e-g). a, c, d Phaeophila dendroides (Crouan and Crouan) (a, c from Thivy 1943, pl. 1/1 and 1/3 figured as Phaeophila engleri Reinke; see Guiry and Guiry 2009, d from Nielsen 1987). b Eugomontia sacculata Kornmann (from Kornmann 1960, fig. 5b). e Bacinella irregularis Radoičić with opposite branching resulting in a characteristic "four-armed cen- tral cell" (Nielsen 1987); note the boring into the fine-branching filaments of the erect system of Lithocodium aggregatum Elliott. f Bacinella irregularis Radoičić predominantly chasmoendolithic within interseptal spaces of coral. $\mathbf{g}$ Bacinella irregularis Radoičić chasmoendolithic within demosponge skeleton; note characteristic short barrel-shaped cells (compare holotype specimen, Fig. 11a). Scale bars $0.2 \mathrm{~mm}$ for $\mathbf{a}, \mathbf{g} ; 1.0 \mathrm{~mm}$ for $\mathbf{f}$. Thin sections: e H0-16V, f CAL-1, $\mathbf{g}$ SE-2V 

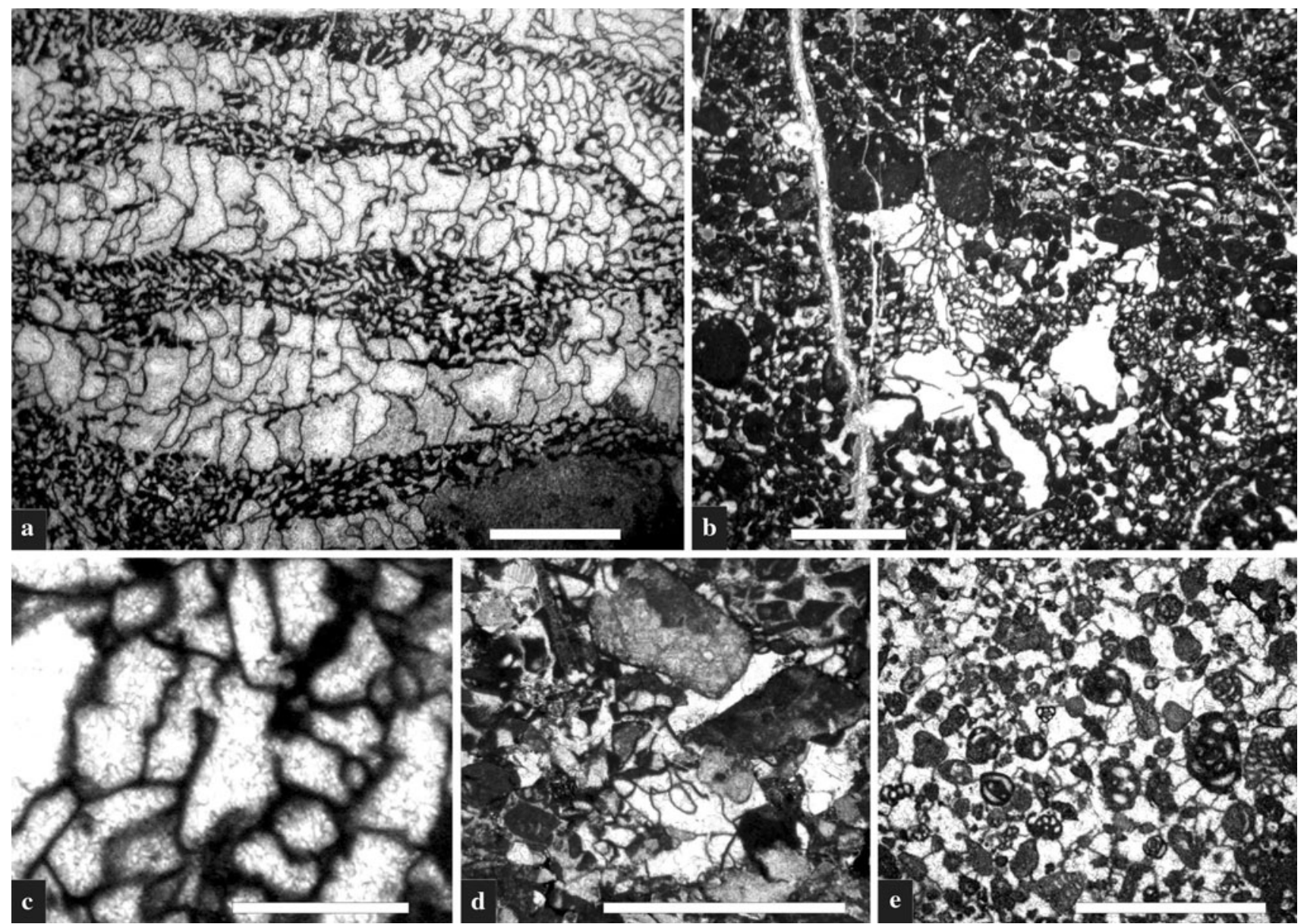

Fig. 13 Upper Jurassic-Upper Cretaceous "lithocodoid-bacinelloid" fabrics (sensu Neuweiler and Reitner 1992) from the Northern Calcareous Alps of Austria (a-c), Germany (d) and the Lower Cretaceous of Hungary (e). a Large masse of alternating fine-cellular "bacinelloid" and more micrite-rich "lithocodoid" fabric and large-vesicular sparitefilled bacinelloid fabric of unknown taxonomic position; reefal platform margin facies. Tithonian of Austria, Northern Calcareous Alps. b Bindstone with bacinelloid fabric consisting of differently sized and shaped sparitic vesicles binding bioclasts (e.g., foraminifera) and lithoclasts (e.g., peloids). Back-reefal to open lagoonal facies. Upper Kimmeridgian of Austria, Northern Calcareous Alps. c Detail from

poorly understood. In these cases, however, it is necessary first to ascertain whether these micritic structures really belong to Lithocodium or not, see Fig. 13a, for example.

Order: Ulvales

Family: Phaeophilaceae

Genus: Phaeophila Hauck

Phaeophila? sp.

(Figure 14a)

Description Creeping filaments (diameter $24-55 \mu \mathrm{m}$ ) with constrictions and several more or less parallel long hairs (setae) rising upwards and stretching into the erect filament system of Lithocodium aggregatum. The hairs stretch obliquely to the prostrate filament; they are 15-20 $\mu \mathrm{m}$ thick b showing individual vesicles (possibly cells) that are partly connected to each other by means of small pores. $\mathbf{d}$ Filamentous fabric connecting different lithoclasts in a high-energy shore-zone depositional setting (so-called Untersberg Marmor). Upper Cretaceous (Late Turonian or Coniacian) of Germany, Northern Calcareous Alps. e Bacinelloid fabric (or Bacinella-bindstones in literature) binding bioclasts (mostly small benthic foraminifera) and lithoclasts (mostly peloids); back-reef to open lagoonal facies, Lower Cretaceous of Hungary. Scale bars $2 \mathrm{~mm}$ for $\mathbf{a}-\mathbf{b} ; 1.0 \mathrm{~mm}$ for $\mathbf{d} ; 0.5 \mathrm{~mm}$ for $\mathbf{c}, \mathbf{e}$. Thin sections: a TK $8, \mathbf{b}$, c HW-1, d C-128, e Naghy-2

and up to $700 \mu \mathrm{m}$ long. The three-dimensional structure (e.g., possible branchings) is unknown. The sinuous appearance of the filaments with constrictions suggests a septate structure; septae, however, are not preserved.

Remarks The life cycle of Phaeophila and other endolithic chlorophytes is rather short (weeks to a month), so that normally only empty borings are found in substrates (Kiene et al. 1995). Other similar euendolithic ulvalean algae with thin upright hairs are Acrochaete Pringsheim or Entocladia Reinke (Fig. 14b-d) (e.g., Thivy 1943). These microfilamentous algae are typically endophytic, e.g., they live inside the thalli of brown algae (Srinivasan 1962; Correa et al. 1987, 1988; Kitayama and Garrigue 1998). Whether the Lower Cretaceous forms 


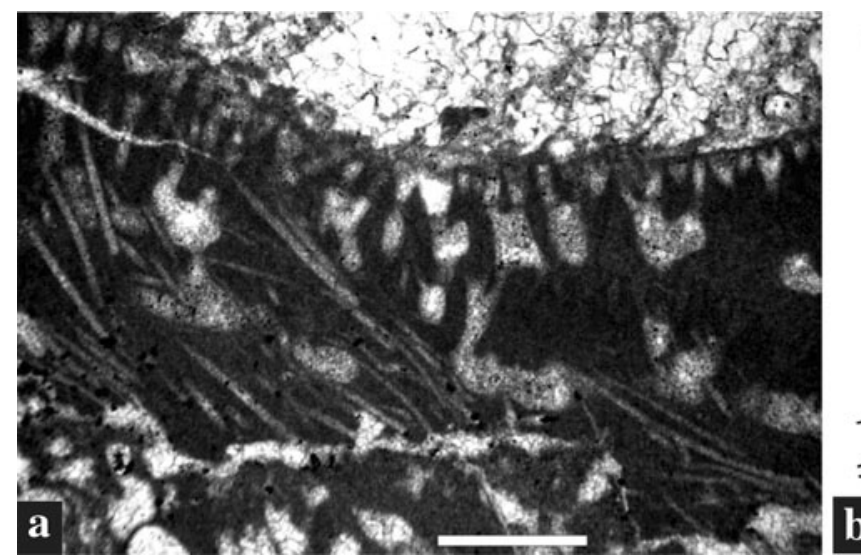

Fig. 14 Euendolithic chlorophyte Phaeophila? sp. from the Lower Aptian of the western Maestrat Basin (a) compared to modern counterparts (b-d). a Phaeophila? sp., filament with irregular constrictions delineating uniseriate cells (cross-walls not preserved) from which thin, more or less isodiametric, bristle-like hairs (setae) arise; euendolithic within Lithocodium crusts. b Entocladia vagans (Börgensen) with one hair emerging from each cell (from Thivy 1943, pl. 4/4,

infested living or already dead Lithocodium thalli is unknown.

Class: Bryopsidophyceae

Order: Bryopsidales

Family: Ostreobiaceae

Genus: Ostreobium Bornet and Flahault

Ostreobium? sp.

(Figures 15a-f, 17h, i, pars)

Description Siphonous (non-septate) straight and unconstricted tubes, euendolithic within the micritic Lithocodium tissue and stretching cryptoendolithically in borings produced by other organisms or more often in the prostrate system of Lithocodium aggregatum. In the latter case, the tubes typically attach closely to the roof of the crypts of (mostly) larger diameters (Fig. 15b, c). The tubes have diameters of $40-145 \mu \mathrm{m}$, the wall thickness is $\sim 8-12 \mu \mathrm{m}$; greatest observed tube length more than $5 \mathrm{~mm}$ (Fig. 15a); tube ends swollen (up to $200 \mu \mathrm{m}$ ). The straight crust-parallel tubes occur in a zone about 0.2 to $0.5 \mathrm{~mm}$ below the crust surface and show upward-branching with a slight terminal swelling stretching into the lower part of the erect filament system of Lithocodium (Fig. 15b, d-f). The thin tube wall appears dark when micritic; in random sections through the wall it appears translucent slightly yellowish to brownish.

Remarks The cryptoendolithic tubes were already recognized and illustrated by Banner et al. (1990, pl. 2/1, 3, p. 28 ) and incorrectly identified as, "distinctly tubular" medullary filaments. Our specimens, although a little larger, are very similar if not identical to the siphonaceous microendoliths within microsolenid corals from the Lower Aptian of Romania reported by Kolodziej et al. (2008). The long

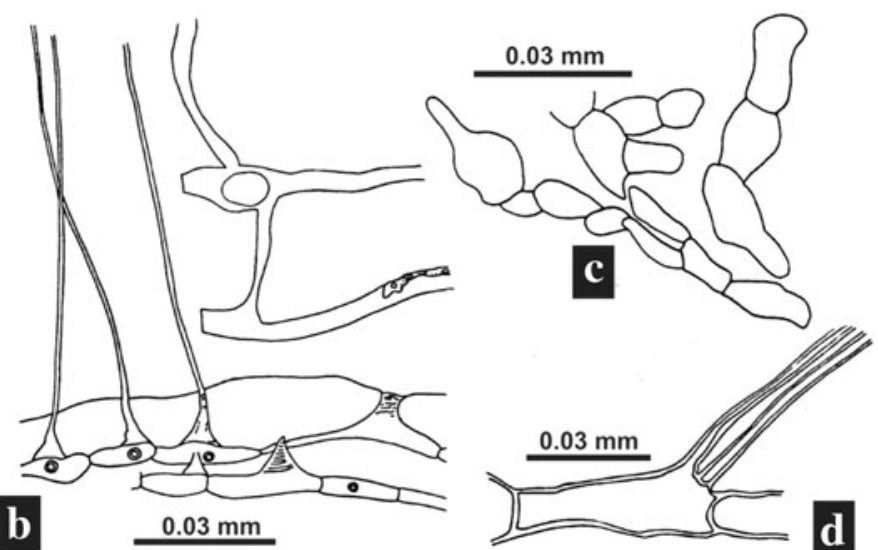

figured as Ectochaete vagans). c Phaeophila dendroides (Crouan and Crouan) showing uniseriate cell arrangement (from Thivy 1943, pl. 2/ 16 figured as Phaeophila engleri). d Phaeophila dendroides (Crouan and Crouan), detail showing several hairs ("setae") emerging from each cell (from Thivy 1943, pl. 2/6 figured as Phaeophila engleri). Scale bar $0.3 \mathrm{~mm}$ for a. Thin section: a $\mathrm{H} 0-4 \mathrm{H}$

straight and branching forms have diameters from 20 to $80 \mu \mathrm{m}$ and were tentatively assigned to Ostreobium; their iron-impregnation gives the tubes a red-brownish color. It is noteworthy that the tube diameters of modern Ostreobium species are usually distinctly smaller, e.g., 3-6 $\mu \mathrm{m}$ for the widespread $O$. quekettii Bornet and Flahault (e.g., Lukas 1974; Tribollet 2008). The largest modern representative is Ostreobium brabantium Weber van Bosse with siphon diameters of $40-60 \mu \mathrm{m}$ enlarging up to $150 \mu \mathrm{m}$ at points of bifurcation (Budd and Perkins 1980, p. 885). Ostreobium represents a typical microeuendolith in modern hermatypic corals where it forms a typical green endolithic banding below the living skeleton surface, the so-called Ostreobium band or layer (e.g., Le Campion-Alsumard et al. 1995; Tribollet and Payri 2001; Försterra et al. 2005; Magnusson et al. 2007). Ostreobium was also observed as an endophyte within coralline algae (Ghirardelli 2002). The stretching that is often observed of the tubes at the roofs of empty borings or prostrate Lithocodium filaments can be interpreted as a phototactic growth. Ostreobium belongs to more than one category in the scheme of Golubic et al. (1981) as it can leave its boreholes (euendolith) and stretch into existing cavities/structures (cryptoendolith) of the substrate (Schroeder 1972; Golubić et al. 1975; Kobluk and Risk 1977); an observation also made in our material. This euendolithic chlorophyte has been reported from water depths ranging from 1.5 to $60 \mathrm{~m}$ (e.g., Lukas 1974).

\section{Calcimicrobes \\ Epiphyton group \\ (Figure 16a-e, g)}

Remarks The predominantly Paleozoic Epiphyton group sensu Riding (1991a) comprises micritic, dendritic filaments 

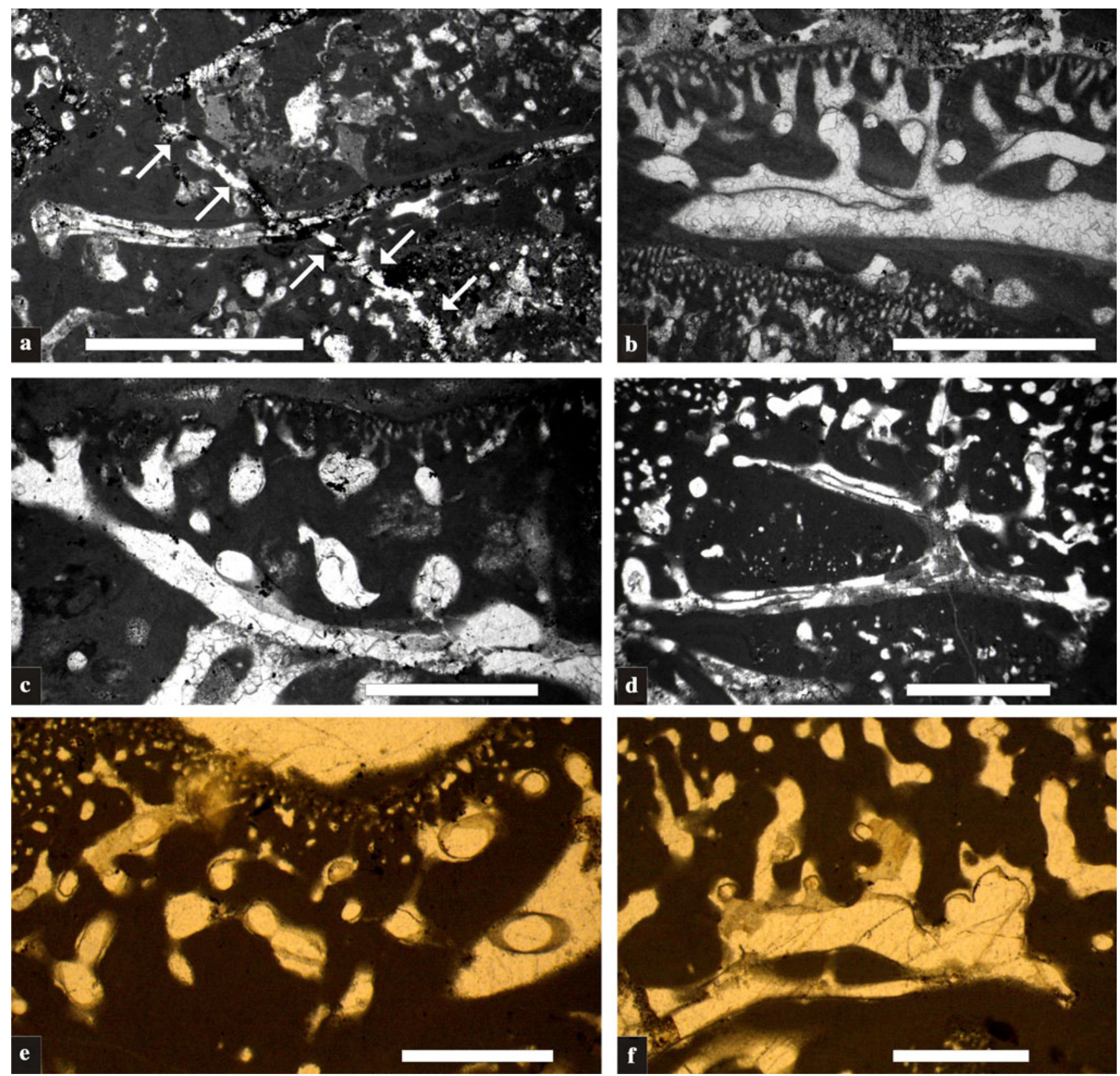

Fig. 15 Cryptoendolithic and euendolithic chlorophyte Ostreobium? sp. from the Lower Aptian of the western Maestrat Basin. a Long straight tube within Lithocodium crusts; note the overprinting by the boring gallery (arrows). b-c Lithocodium crusts with cryptoendoliths attaching to the roof of a prostrate filament or bored gallery and branching upwards into the erect system. $\mathbf{d}$ Endolithic branching chlo-

of erect or pendant growth. Sometimes, also tufted masses of clotted micrite structures are observable referable to decayed Epiphyton-type filaments; another interpretation would explain them as microbial precipitates. These Epiphyton-type filaments were observed in the outermost crusts, preferentially inside the sparite-filled terminal megacells. Similar arborescent calcimicrobes are reported from modern stromatolites of Tonga as Frutexites-type by Kazmierczak and Kempe (2006, fig. 3g). rophyte tube boring into Lithocodium crusts. e-f Euendolithic chlorophyte tube, note the swelling at the branching areas; tube wall thin, greater thickness results from oblique cutting (e, right). Scale bars $1 \mathrm{~mm}$ for a-d; $0.5 \mathrm{~mm}$ for $\mathbf{e}-\mathbf{f}$. Thin sections: a CA-3H, b DE- $5 \mathrm{H}, \mathbf{c}$ H0-6V, d-f H0-11

It is unclear whether these calcimicrobes were dwelling in living (as cyanosymbionts) or dead Lithocodium tissue. Cyanobacteria as symbionts within Ulvovyceae/Chlorophyceae are known since the latest Proterozoic (Raven 2002). Epiphyton was illustrated by Masse (1979) from the Lower Cretaceous; according to Riding (1991a) this form, however, more closely resembles Angulocellularia. Comparable filamentous structures within Lower Cretaceous "Bacinella" pseudocells were already observed by Granier 

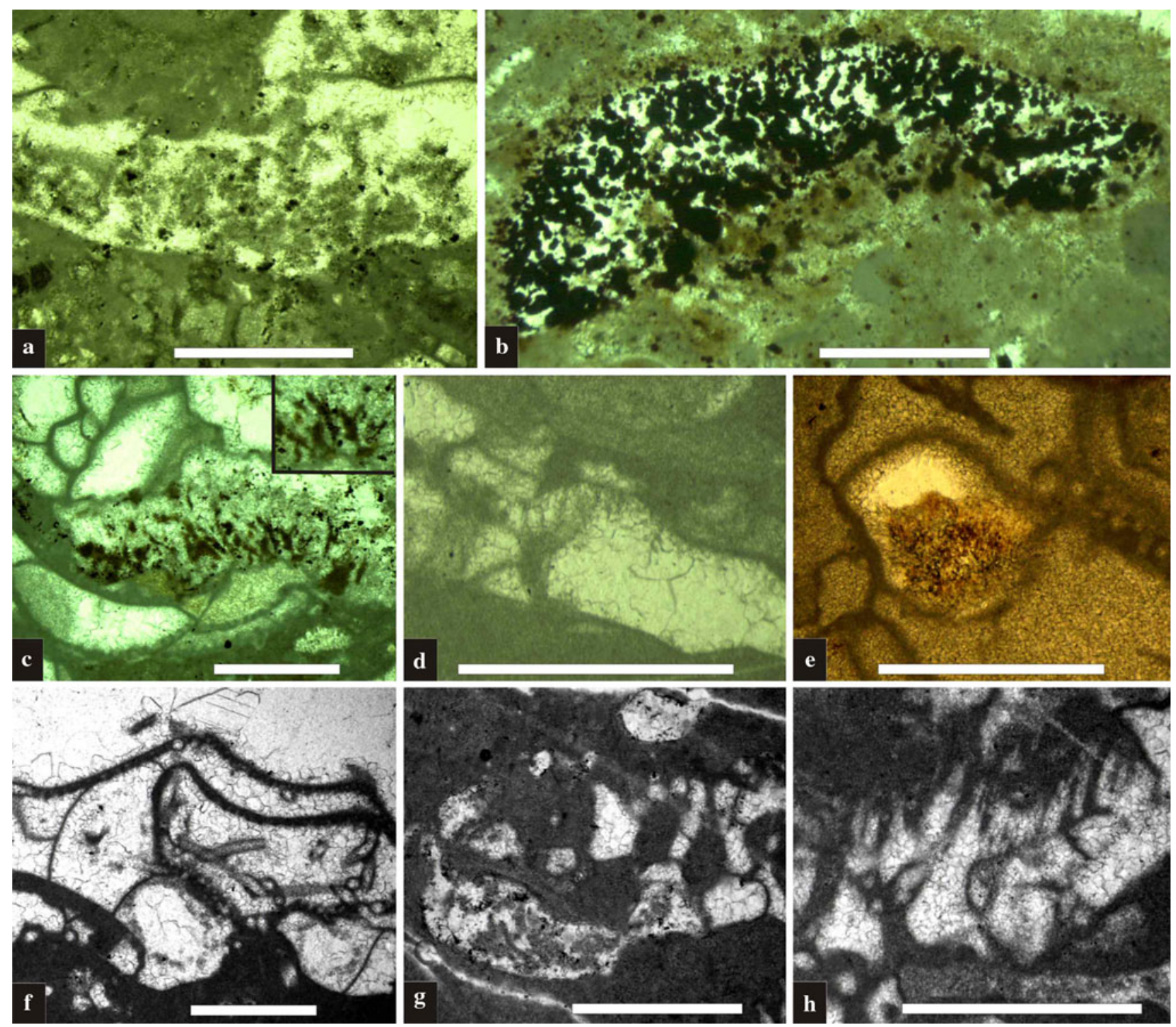

Fig. 16 Calcimicrobes (cyanobacteria) associated with Lithocodium aggregatum Elliott from the Lower Aptian of the western Maestrat Basin. a-c, g Epiphyton group sensu Riding (1991a), with micritic erect to pendant dendritic filaments in aberrant terminal vesicles of Lithocodium aggregatum $(\mathbf{a}, \mathbf{c}, \mathbf{d})$ and thick prostrate filaments $(\mathbf{g})$. d Single erect branching filament. e Altered filaments (?Epiphyton group) geopetally filling within terminal vesicles of Lithocodium

(Granier 2003, fig. 6), who remarked that their degradation and decay may result in the commonly observed pseudosparite completely or partly (geopetally) filling these pseudocells. Equivalent observations were also made by Rameil et al. (2010, fig. 2a), interpreted as "collapsed walls" caused by "mechanical burial compaction". They are here interpreted as decaying or collapsed filaments geopetally filling the basal parts of the pseudocells. It can be assumed that the filaments recorded within Lithocodium-Bacinella crusts by Maurin et al. (1985), unfortunately without illustration, also correspond to the "tiny Epiphyton-like bushes". aggregatum. f Girvanella group sensu Riding (1991a), with simple, loosely packed, flexuous, isodiametric, hollow tubes with microgranular walls inside terminal vesicle of Lithocodium aggregatum. h Filaments with swollen basal part and herringbone-like branching. Scale bar $0.5 \mathrm{~mm}$ for $\mathbf{a}-\mathbf{h}$. Thin sections: a-c CUB-41, d DE-2HB, e H0-11V, f $\mathrm{DE}-3 \mathrm{H}, \mathbf{g ~ S E}-2 \mathrm{H}, \mathbf{h} \mathrm{H} 0-6 \mathrm{~V}$

\section{Girvanella group}

(Figure 16f)

Remarks The Girvanella group sensu Riding (1991a) comprises thin-walled more or less isodiametric simple flexuous tubes (see also Riding 1977). Like the Epiphyton group, loosely packed Girvanella-type tubes were observed inside the large sparite-filled terminal cells of Lithocodium aggregatum. The external tube diameters are 50-65 $\mu \mathrm{m}$; the thickness of the thin microgranular walls is $\sim 8-14 \mu \mathrm{m}$. In the material studied, Girvanella-like tubes are distinctly 
more rare than the bushy filaments of the Epiphyton group. It is noteworthy that Waite et al. (2007) also report the association of Lithocodium with Girvanella from Late Albian boundstones of Texas. Fenninger (1972, pl. 3/4) observed irregularly arranged filaments (diameter including the wall: $20 \mu \mathrm{m}$ ) reminiscent of Girvanella tubes inside "Bacinella" tissue, and considered a possible algal or fungal origin. Comparable filaments/tubes were also reported by Schott (Schott 1983, pl.1/4) from Late Triassic intertidal algal laminites with bacinelloid texture.

\section{Bioerosion features in Lower Cretaceous crusts of Lithocodium aggregatum Elliott}

\author{
Macroborings \\ Indet 1 \\ (Figures 4b, d, h, 17a, b pars, c, j)
}

Description Borings either perpendicular or oblique to the crust surface; rather long (several $\mathrm{mm}$ ) passing through several crust layers and consisting of a thick main channel (width up to $0.4 \mathrm{~mm}$ ) and occasionally long, though more often short, lateral branches. The latter are often formed at the boundaries between superimposed crust layers. In perpendicular borings, this branching leads to a rectangular pattern (Fig. 17j). The diameter of the main channel may undulate (Fig. 17b) or increase in the boring direction (Fig. 17a). This type may show irregular terminal branching with fine short branches stretching to the crust surface (Fig. 17a). In many cases where only smaller parts of the borings are observable in the thin sections, the boring direction cannot be determined reliably.

Remarks This macroboring type is common in the material from the Lower Aptian of the western Maestrat Basin. It also occurs in the type-material of Elliott (1956) (Fig. 4b, $\mathrm{d}, \mathrm{h}$ ). What produced this macroboring is unknown; the general pattern might point to a chlorophyte alga.

Indet 2

(Figure 17b pars, d-f, h, i pars)

Description It is characterized by tubular, slightly undulating, channels of variable diameter bearing spheroidal to ovoidal swellings, often slightly lateral in position. The swellings are distinctly larger (up to $200 \mu \mathrm{m}$ thick, up to $300 \mu \mathrm{m}$ long) than the channels. The distance between successive swellings ranges from $0.15 \mathrm{~mm}$ to more than $1 \mathrm{~mm}$. The diameter of the channels is highly variable, often between 28 and $38 \mu \mathrm{m}$. In some cases, the diameter decreases in the boring direction by much as $150 \mu \mathrm{m}$. Rather long (up to $500 \mu \mathrm{m}$ ) hairs can be observed occasionally (Fig. 17h).

Remarks This macroboring is the most common form observed in the thalli of Lithocodium aggregatum from the
Fig. 17 Boring patterns within Lower Cretaceous crusts of Lithocodium aggregatum Elliott (Spain: a-d, h-j; Iraq: e-f; Abu Dhabi: g). a Boring within several superimposed crusts (dotted white lines, crust surface: solid line) showing terminal branchings comparable to the epilithic Lithocodium ( $M=$ matrix, $B=$ foraminifer Bdelloidina? urgonensis Wernli and Schulte, Go = Gomontia stage within pelecypod shell). b-c, $\mathbf{j}$ Boring almost perpendicular to the crust surface with several short lateral branches on both sides $(M=$ matrix $)$. $\mathbf{d}-\mathbf{f}$ Boring pattern characterized by thin, slightly undulating channels with round to ovoid swellings, often disposed laterally to the channels. $g$ Thick crusts transjected by several boring patterns. Below: same boring shown in d-f (arrow 1); above: system of thin straight channels with small angle or rectangular branchings, often with small rounded swellings at the branching points (arrows 2), and an indefinite macroboring (arrow 3). $\mathbf{h}-\mathbf{i}$ Boring patterns similar to that shown in $\mathbf{d}-\mathbf{f}$; note the thin long lateral hairs (arrows in $\mathbf{h}$ ) and crypto-/euendolith chlorophyte Ostreobium? (C). Scale bar $1.0 \mathrm{~mm}$ for $\mathbf{a}, \mathbf{b}, \mathbf{i} ; 0.5 \mathrm{~mm}$ for $\mathbf{c}-\mathbf{h}$. Thin sections: a CA-3H, b H0-5V, c CAL-3V, d P0-4V, e-f V 41599, g from Banner (1990, pl. 1/2), h CAL-3vt, i H0-11V. Copyright for e, f Natural History Museum, London

Lower Aptian of the western Maestrat Basin but also the Hauterivian? type-material of Elliott (Fig. 17e, f). This bioerosional pattern bears some resemblance to the ichnogenus Rhopalia Radtke (Radtke 1991; Glaub 1994), which the chlorophyte Phaeophila is commonly considered to produce (e.g., Golubić and Radtke 2008; Heindel et al. 2008). It is noteworthy that the two known ichnospecies of Rhopalia have distinctly smaller dimensions (Radtke 1991; Golubić and Radtke 2008).

\section{Microborings \\ Orthogonum-type}

(Figure 17g pars)

Description This type of boring consists of a system of long (several $\mathrm{mm}$ ) straight, supposedly cylindrical borings of rather uniform diameter (mostly $8-12 \mu \mathrm{m}$; occasionally up to $25 \mu \mathrm{m}$ ). Branching occurs obliquely or at right angles and may form a network. Moderate swellings (diameter 25$40 \mu \mathrm{m}$ ) occur at the branching points.

Remarks This microboring with its typical branching pattern was observed in the illustration of Banner et al. (1990, pl. 1/2) from the Lower Cretaceous of Abu Dhabi. It can be compared with the ichnogenus Orthogonum Radtke (e.g., Radtke 1991; Glaub 1994) known since the Ordovician (Glaub and Vogel 2004; Bromley 2004). Orthogonum is typically arranged parallel to the substrate surface, a feature that cannot be verified from the above-mentioned thinsection illustration. The different ichnospecies of Orthogonum are related to different producers of different biogenic groups (e.g., algae, fungi) (Glaub 1994); for example, Orthogonum fusiferum Radtke is referred to the fungus Ostracoblabe implexa Bornet and Flauhault (e.g., Perry and Macdonald 2002; Carreio-Silva et al. 2009).

A reconstruction of the described morphological stages of Lithocodium aggregatum Elliott and Bacinella 


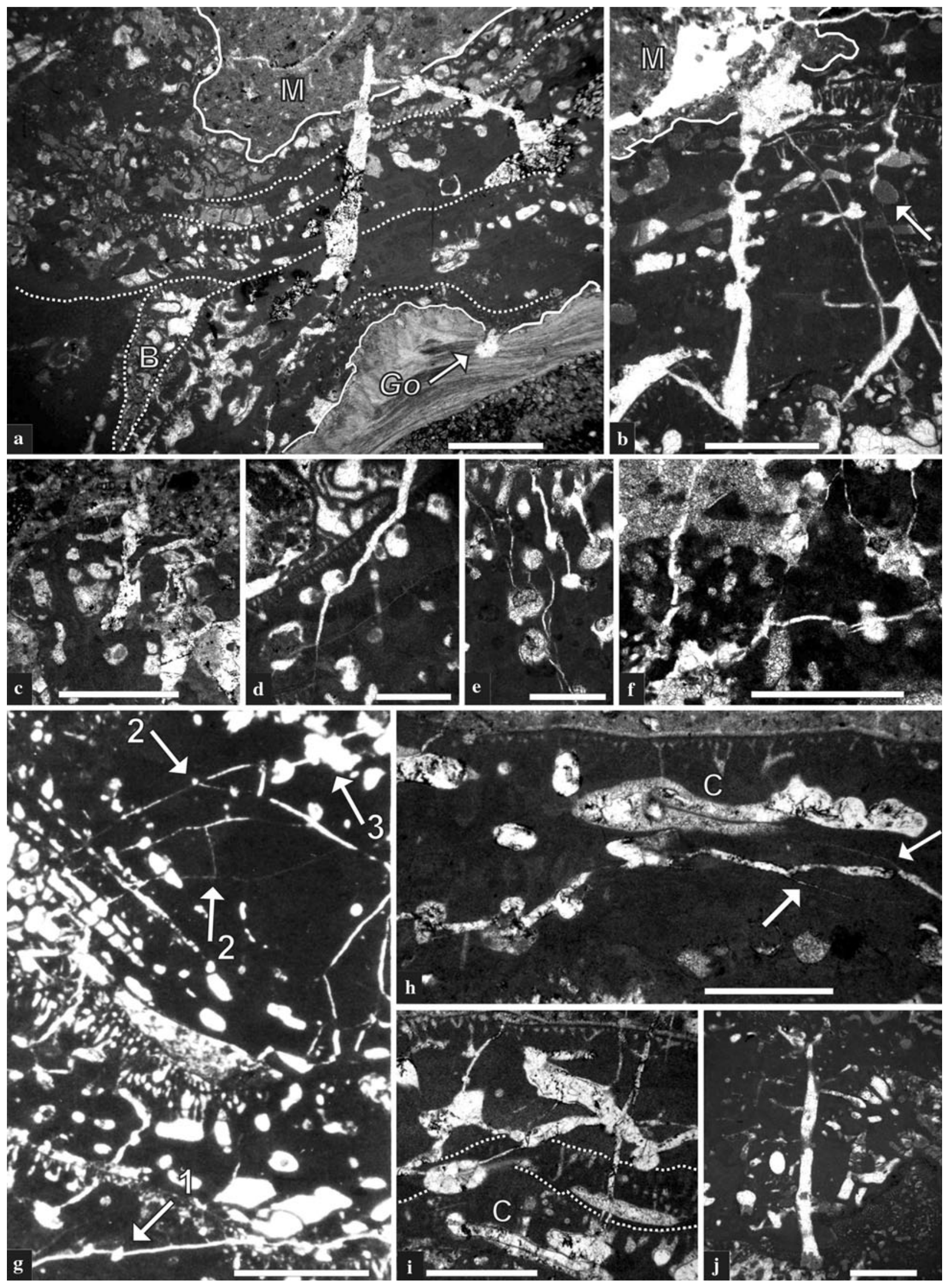




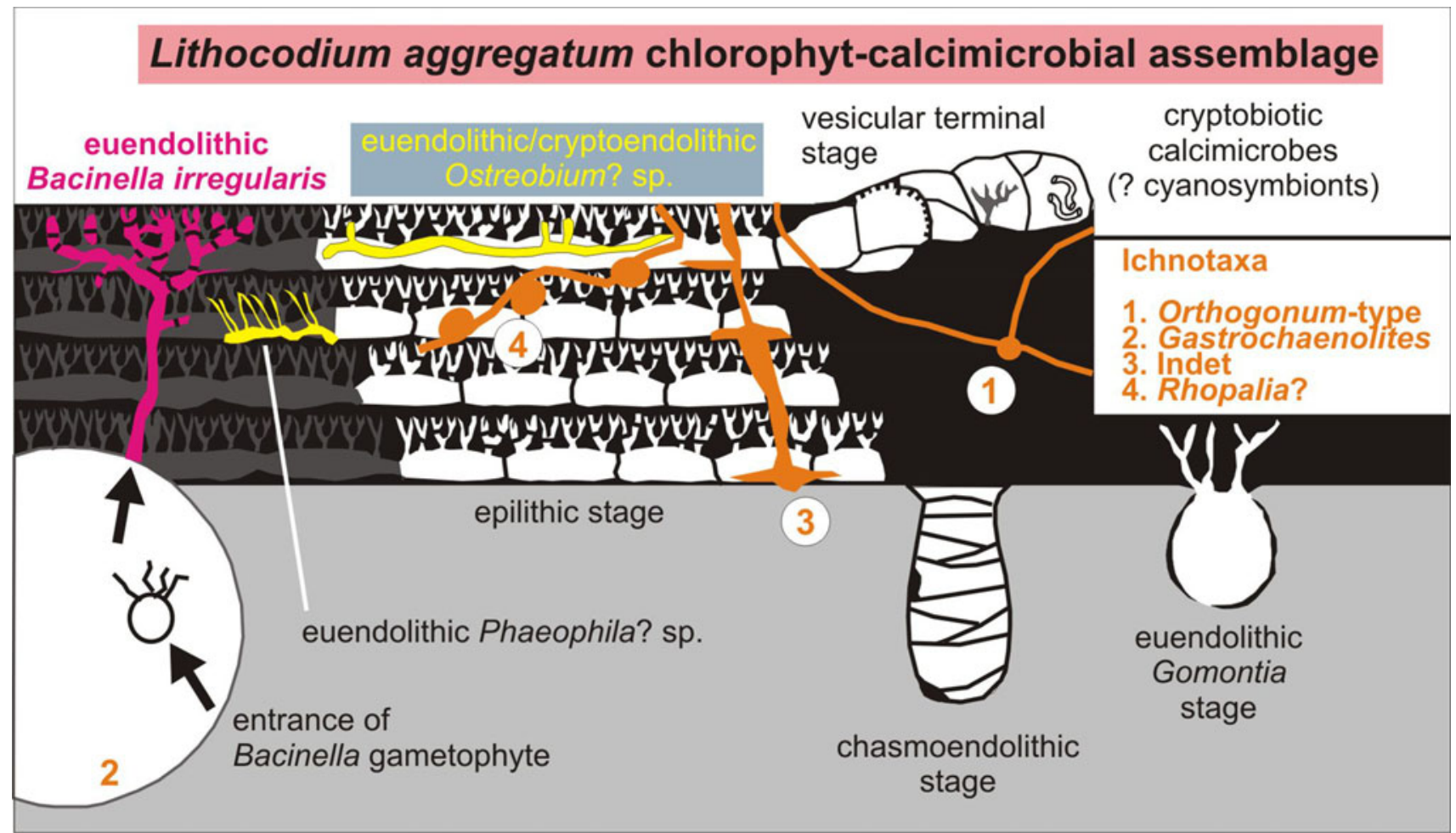

Fig. 18 Schematic drawing (not to scale) of the new taxonomic and morphological interpretation of Lithocodium aggregatum Elliott as a chlorophyte-calcimicrobial assemblage associated with cryptobiotic

irregularis Radoičic together with the observed micro-/ macroborings, the cryptobiotic chlorophyte taxon (Ostreobium? sp.) and the associated calcimicrobes is shown in Fig. 18. It must be stressed that in our reconstruction all these taxa and ichnotaxa co-occur; in fact, it represents a compilation obtained from various thin sections analyzed.

Comments on paleoecology and paleonvironment of the Lithocodium-Bacinella chlorophyte microbial assemblage

The factors leading to or facilitating the proliferation of Lithocodium-Bacinella during certain periods, especially the Lower Cretaceous, have been addressed by several authors. Concerning the described Lower Aptian occurrences of the western Maestrat Basin, a deposition below the fair-weather base (= around $10-20 \mathrm{~m}$, Tucker and Wright 1990) was assumed by Bover-Arnal et al. (2009b) and Bover-Arnal 2010). Certainly, a water depth greater than that usually assumed for shallower parts of the lower photic zone (e.g., Leinfelder et al. 1993, fig. 9) can be postulated. The rare and always very small debris of dasycladalean algae (Table 1) are not in contradiction with this as they are assumed as allochthonous. For the type-material of Lithocodium aggregatum, Elliott (1956) did not indicate microfacies or accompanying biota. The position of the type-locality Rumaila on the paleofacies map for the and euendolithic taxa (ichnocommunity). Bacinella irregularis Radoičić is considered a euendolithic chlorophyte that may bore into the thalli of Lithocodium aggregatum Elliott

Berriasian-Valanginian indicates "shallow-marine carbonates and clastics" (Ziegler 2001, fig. 12). At the type-locality of Lithocodium aggregatum, the occurrence of the stromatoporoid Burgundia cf. ramosa in the type-material should be indicative of inner platform/ramp paleoenvironmental setting (see Leinfelder et al. 2005 for details). Banner et al. (1990, p. 32) concluded paleodepths of abundant in-situ specimens ranging from approximately $15 \mathrm{~m}$ to about $60 \mathrm{~m}$. The associated fauna reported by the authors with neotrocholinids, lenticulinids, echinoderm debris, and rare planktonic foraminifera supports this assumption. From the Hauterivian of the central Maestrat Basin, Götz et al. (2005) described similar Lithocodium crusts associated with corals (e.g., microsolenids). The accompanying microbiota and the bioerosional features are similar to our Lower Aptian occurrence (compare Table 1). The morphological appearance of these crusts is also very similar. The paleoenvironment was interpreted by Götz et al. (2005) as a shallow-water depositional setting within the fair-weather base zone. In any case, there are several data from the Lower Cretaceous occurrences of Lithocodium where greater water depths than those indicated for the Late Jurassic were assumed (some to $>30 \mathrm{~m}$ according to Leinfelder 2001, fig. 11).

For mass occurrences of Lithocodium-type crusts from the Albian of Spain, Neuweiler and Reitner (1992) discussed 
nutrient-rich conditions and/or a shift in seawater carbonate alkalinity. The latter factor was mainly considered because of the high primary production of calcium carbonate, a view recently adopted by Immenhauser et al. (2005) in assuming influx from weathering of emerged carbonatic areas. With respect to this, the partial pressure of atmospheric carbon dioxide should be also considered as another critical factor (Riding 2006 for details). Another important source of calcium carbonate, at least for the Lower Aptian occurrences in Spain, is the bioclasts themselves, which could have favored precipitation of microcrystalline calcite after bioerosive dissolution (e.g., Kobluk and Risk 1977; Chacón et al. 2006; Tribollet 2007 for discussion). Similarly, studies of modern stromatolites from the Bahamas have shown that "micritization is caused by extensive microboring and carbonate precipitation within boreholes concurrent with endolithic activity" (Macintyre et al. 2000, p. 915; Reid and Macintyre 2000). Of course it is not possible to estimate how much of the calcium carbonate preserved in the Lithocodium aggregatum crusts was derived from direct precipitation in the seawater or from dissolution processes of the calcareous substrates. However, as all bioclasts are commonly extensively affected by bioerosion, a considerable contribution of microcrystalline calcite of bioclastic origin to the crust masses seems likely. In recent times, attempts to correlate high trophic levels and rates of microbioerosion have been postulated but with no unambiguous final conclusions (Tribollet 2007 for details).

Some general considerations about the paleoenvironmental significance of the calcimicrobial community (Fig. 16) and the accompanying microfossils (Table 1) present in the thin sections analyzed can be provided. First of all, it is well known that modern microbes are adapted to low light intensities (e.g., Tribollet 2007); this statement should also be valid for fossil counterparts. This, however, does not necessarily mean that they were restricted to deepwater zones. The calcimicrobe Girvanella Nicholson and Etheridge (see Riding 1977, 1991a) shows a wide bathymetric range from shallow subtidal to slope settings; in the Paleozoic it is a characteristic constituent of deep-water mud-mounds (e.g., Pratt 1995). Chlorophytes showing an endolithic Codiolum stage such as Gomontia are reported from the upper photic zone down to the transition of the lower photic/aphotic zones (Le Campion-Alsumard 1979; Budd and Perkins 1980). As already mentioned, the rare and small debris of dasycladalean algae present in our thin sections are assumed to be allochthonous; the paleoecology of the encrusting peyssonneliacean alga Polystrata alba (Pfender), can be compared with the modern Ethelia fosliei Weber van Bosse, known from a depth range of 8-50 m (Massieux and Denizot 1964; Bassi 1997). These examples clearly demonstrate that an unequivocal paleobathymetric interpretation of the Lower Aptian Lithocodium-type crusts cannot be deduced from the chlorophyte-calcimicrobial assemblage alone at the present state of knowledge.

Mass occurrences (bloom periods) of Lithocodium aggregatum crusts from the Late Hauterivian in southeast France (Conrad and Clavel 2008) and from some Lower Aptian occurrences where referred to as "microbial events" (Immenhauser et al. 2005). For the Lower Aptian Lithocodium blooms, a relation to the time-equivalent Oceanic Anoxic Event 1a (OAE1a; Selli level) was envisaged recently, however, with the triggering factors of these widespread blooms still poorly understood (Immenhauser et al. 2005, 2009; Bover-Arnal et al. 2009b; Bover-Arnal 2010; Rameil et al. 2010). It is noteworthy that the description as "microbial-foraminiferal" episode made by Immenhauser et al. (2005) referred to the interpretation of the micritic Lithocodium-type crust as representing a lituolid foraminifera following the model of Schmid and Leinfelder (1996). Discussing the possible driving factors for the initiation of the OAE1a coeval Lithocodium-episode, Immenhauser et al. (2005) also mentioned that, according to Erbacher et al. (1996), the OAE1 should coincide with a transgressive period. A comparable interpretation was also put forward by Waite et al. (2007). Those authors reported a characteristic widespread marker bed from the Upper Albian of Texas consisting of a dark-colored Lithocodium boundstone (up to $3.6 \mathrm{~m}$ thick) traceable over large distances, which interrupts normal shelf margin facies. Following the interpretation of the sequence stratigraphic framework provided by these authors, this marker bed characterizes "the maximum flooding interval of a single thirdorder depositional cycle" and records "an important environmental change across the platform". However, further details of what kind of changes these actually were have not been given by Waite et al. (2007). Another example was published from the Late Oxfordian of the Swiss Jura Mountains by Védrine et al. (2007). These authors reported a patchy distribution of "Bacinella-Lithocodium" oncoids, concentrated around maximum-flooding periods and in highstand deposits "where low-energy conditions existed in relatively deep water but still in the photic zone". For the Lower Aptian occurrences in the western Maestrat Basin, the levels with the encrusted coral rubble deposits with Lithocodium aggregatum should mark the start of the late Early Aptian Tethyan-wide regressive context that in the Galve sub-basin ended with subaerial exposure of platform carbonates at the uppermost Early Aptian (Bover-Arnal et al. 2009a, b). All the examples mentioned seem to indicate a relationship between the abundant occurrences of Lithocodium aggregatum-crusts and relative changes in sea level, as evidenced by sequence stratigraphic analyses and the paleoenvironmental disturbances involved.

In the aforementioned Lower Aptian case study from the western Maestrat Basin, an encrustation of dead coral 
skeletons was assumed by Bover-Arnal et al. (2009b) and Bover-Arnal (2010). This view is in good accordance with observations from modern reefs, where living corals are mainly infested by passive endoliths (e.g., cryptoendoliths) whereas dead surfaces are actively bored (e.g., Scoffin and Bradshaw 2000). Analyzing Late Jurassic specimens, Bertling and Insalaço (1998, p. 156) made equivalent observations, assuming that living corals did not show equivalent boring densities "because of their protective cover of living tissue". Also the overall presence of macroborings (Gastrochaenolites) is a typical post-mortem feature (e.g., Tapanila et al. 2004). The intense chlorophyte (micro-)bioerosion was obviously favored by an assumed low sedimentation rate. A possible link between high trophic levels and the mass-occurrence of the Lithocodium-Bacinella-type crusts described in the present paper was already envisaged by Bover-Arnal et al. (2009b) and Bover-Arnal (2010) in modern reefal environments, high rates of microbioerosion have been attributed to an increasing nutrient supply (e.g., Smith et al. 1981; Rose and Risk 1985; Holmes et al. 2000; Carreio-Silva et al. 2005). Rameil et al. (2010, fig. 10) presented the distribution of Lithocodium-crusts in dependence to trophic level, estimating a clear dominance in mesotrophic settings.

In conclusion, the paleoenvironmental significance of Lithocodium aggregatum occurrences must be carefully viewed in each case study. The scarce literature dealing with this topic, however, points to increased nutrient concentrations, which could have stimulated blooms of the chlorophyte Lithocodium aggregatum Elliott. Furthermore, the associated calcimicrobial paleocommunity and the micro-/macroendolithic community patterns should show differences depending on the water depth where these crusts were formed, as observed in modern taxa (e.g., Golubić et al. 1975; Le Campion-Alsumard 1979; Budd and Perkins 1980; Günther 1990; Glaub 1994; Perry 1998; Glaub 1994; Radtke and Golubić 2005; Gektidis et al. 2006; Glaub et al. 2007; Heindel et al. 2008). Concerning the Lower Aptian Lithocodiumcrusts in the western Maestrat Basin, the uncertainty of the taxonomic calcimicrobial and ichnotaxonomical composition does not allow a clear conclusion concerning the paleodepth. The data in the literature show that Lithocodium aggregatum can occur in shallow-marine settings together with dasycladalean algae but also in deeper water areas (slope, outer shelf) together with planktonic foraminifera. The factors leading to massabundances of the Lithocodium-type crusts in certain levels/periods is so far poorly understood, but offers a wide area for future research combining geochemical, micropaleontological, biostratigraphical, and sedimentological approaches.

\section{Conclusions}

- If we refer to the internal thallus structure, none of the descriptions provided by Elliott (1956) or Radoičić (1959) are complete. Lithocodium aggregatum Elliott in its original description represents an ambiguous taxon that cannot reliably be determined as representing a mixup or assemblage of epilithic-euendolithic chlorophytes and calcimicrobes with an overprint of ichnotaxonomical fabrics. In the Lower Cretaceous, this typical association can be characterized as Lithocodium aggregatum-chlorophyte-microbial assemblage. Lithocodium aggregatum Elliott is epitypified and redescribed as a filamentousseptate green alga that exhibits a heterotrichale thallus morphology. Also, with its irregular developed vesicular final stage, Lithocodium cannot be compared closer with any modern taxon.

- For the time being, Bacinella Radoičić is considered a separate genus, a boring filamentous-septate green alga with affinities to the modern ulvalean alga Eugomontia Kornmann. Details of the species-specific live histories of the two algae Bacinella and Lithocodium are still unknown. Therefore, a sporophyte Gomontia-phase typically associated with Lithocodium-crusts is only tentatively referred to Lithocodium Elliott. As the original material of Bacinella was not available for re-study, it cannot be ruled out that the holotype figuration of Bacinella represents a section through the prostrate branching system of Lithocodium, then representing its junior synonym.

- The maintenance of the Lithocodioidea Banner, Finch and Simmons as a subfamily of the Codiaceae or Udoteaceae is challenged as Lithocodium must be excluded, and it is rather doubtful that the other genus assigned to this subfamily, Radoicicinellopsis, belongs to the siphonous green algae.

- The Late Triassic and most of the Late Jurassic specimens that were referred to Lithocodium aggregatum Elliott are different and need taxonomic revision.

- Changes in trophic levels may have led to bloom periods of the epilithic alga Lithocodium aggregatum Elliott and its association of invasive chlorophytes and calcimicrobes in the Lower Cretaceous.

Acknowledgments The Natural History Museum in London is especially thanked for preparing new photographs of the type-material of Lithocodium aggregatum Elliott. Boguslaw Kolodziej (Kraków), Ioan Bucur and Emanoil Săsăran (both Cluj-Napoca), Martin Nose (Munich), Rajka Radoičić (Belgrade), and Stefan Götz (Heidelberg) kindly provided figures from Upper Jurassic-Lower Cretaceous material. The present work benefitted from discussions with Marc Conrad (Perly) and Rolf Schroeder (Frankfurt a. Main). We also thank Josep A. Moreno-Bedmar (Barcelona) for his help in sampling. Funding for this study came from the project Bi 1074/1-2 of the Deutsche 
Forschungsgemeinschaft, the I + D + i research projects: CGL200507445-CO3-01 and CGL2008-04916, the Consolider-Ingenio 2010 programme, under CSD 2006-0004 "Topo-Iberia" and the Grup Consolidat de Recerca "Geologia Sedimentària" (2009SGR-1451). Review comments by Ioan Bucur (Cluj-Napoca) and anonymous reviewer are kindly acknowledged.

\section{References}

Banner FT, Finch EM, Simmons MD (1990) On Lithocodium Elliott (Calcareous algae); its paleobiological and stratigraphical significance. J Micropaleontol 9:21-36

Bassi D (1997) Vegetative anatomy and palaeoecology of Polystrata alba (Pfender) Denizot, 1968 (Cryptonemiales, Peyssonneliaceae) from the Upper Eocene of northern Italy. Rev Paléobiol 16:309-320

Bassoullet JP, Bernier P, Deloffre R, Génot P, Poncet J, Roux A (1983) Les algues Udoteacées du Paléozoïque au Cénozoïque. Bull Centre Rech Explor-Prod Elf-Aquitaine 7:449-621

Beckmann JP, Beckmann R (1966) Calcareous algae from the Cretaceous and Tertiary of Cuba. Mém suisses Paléont 85:1-45

Bertling M, Insalaço E (1998) Late Jurassic coral/microbial reefs from the northern Paris Basin-facies, palaeoecology and palaeobiogeography. Palaeogeogr Palaeoclimatol Palaeoecol 139:139-175

Bertling M, Braddy SJ, Bromley RG, Demathieu GD, Genise J, Mikulas R, Nielsen JK, Nielsen KSS, Rindsberg AK, Schlirf M, Uchman A (2006) Names for trace fossils: a uniform approach. Lethaia 39:265-286

Bover-Arnal T (2010) The Aptian evolution of the Galve sub-basin (Maestrat Basin; E Iberia). Unpublished PhD thesis, Universität Bayreuth, $222 \mathrm{pp}$

Bover-Arnal T, Salas R, Moreno-Bedmar JA, Bitzer K (2009a) Sequence stratigraphy and architecture of a late Early-Middle Aptian carbonate platform succession from the western Maestrat Basin (Iberian Chain, Spain). Sediment Geol 219:280-301

Bover-Arnal T, Salas R, Martín-Closas C, Moreno-Bedmar JA, Bitzer K (2009b) OAE1 a coeval Lithocodium-Bacinella binding of coral rubble piles in the Early Aptian of the western Maestrat Basin (E Iberia). In: Basso D, Caragnano A, Bracchi V, Benzoni F (eds) Abstract book-International Fossil Algae Association (IFAA) 6th Regional Symposium, 1-5 July 2009, Milan, Italy, pp 15-16

Bover-Arnal T, Moreno-Bedmar JA, Salas R, Skelton PW, Bitzer K, Gili E (2010) Sedimentary evolution of an Aptian syn-rift carbonate system (Maestrat Basin, E Spain): effects of accommodation and environmental change. Geol Acta (in press)

Bromley RG (2004) A stratigraphy of marine bioerosion. In: McIlroy D (ed) The application of ichnology to palaeoenvironmental and stratigraphic analysis. Geol Soc Lond Spec Pub 228:455-479

Browne KM, Golubić S, Seong-Joo L (2000) Shallow marine microbial carbonate deposits. In: Riding RR, Awramik SM (eds) Microbial sediments. Springer, Berlin Heidelberg New York, pp 233-249

Bucur II, Săsăran L, Săsăran E, Schuller V (2004) Micropaleontological study of the limestone olistoliths within the Upper Cretaceous wildflysch from Hăsdate (Eastern border of the Gilău Mountains). Acta Palaeontol Romaniae 4:55-67

Budd DA, Perkins RD (1980) Bathymetric zonation and paleoecological significance of microborings in Puerto Rican shelf and slope sediments. J Sediment Petrol 50:881-904

Burne RV, Moore LS (1987) Microbialites: Organosedimentary deposits of benthic microbial communities. Palaios 2:241-254

Camoin G, Maurin AF (1988) Roles des microorganismes (bactéries, cyanobactéries) dans la genese des « Mud Mounds ». Exemples du Turonien des Jebels Bireno et Mirhila (Tunisie). C R Acad Sci Paris 307:401-407

Canérot J, Crespo A, Navarro D (1979) Montalbán, hoja n 518. Mapa Geológico de España 1:50.000. $2^{a}$ Serie. $1^{a}$ Edición. Servicio de Publicaciones, Ministerio de Industria y Energía, Madrid 31 pp

Canérot J, Cugny P, Pardo G, Salas R, Villena J (1982) Ibérica CentralMaestrazgo. In: García A (ed) El Cretácico de España. Universidad Complutense de Madrid, Madrid, pp 273-344

Carreio-Silva M, McClanahan TR, Kiene WE (2005) The role of inorganic nutrients and herbivory in controlling microbioerosion of carbonate substratum. Coral Reefs 24:214-221

Carreio-Silva M, McClanahan TR, Kiene WE (2009) Effects of inorganic nutrients and organic matter on microbial euendoliths community composition and microbioerosion rates. Mar Ecol Prog Ser 392:1-15

Chacón E, Berrendero E, Pichel FG (2006) Biogeological signatures of microboring cyanobacterial communities in marine carbonates from Cabo Rojo, Puerto Rico. Sed Geol 185:215-228

Chafetz HS, Buczynski C (1992) Bacterially induced lithification of microbial mats. Palaios 7:277-293

Cherchi A, Schroeder R (2005) Calcimicrobial oncoid coatings from the Pliensbachian Massone Member (Calcare Grigi Formation, Trento Platform, Italy). Preliminary communication. In: Fugagnoli A, Bassi D (eds) Giornata di Studi Paleontologici "Prof. Carmen Loriga Broglio". Ann Univ Ferrara Vol Spec:45-49

Cherchi A, Schroeder R (2006) Remarks on the systematic position of Lithocodium Elliott, a problematic microorganism from the Mesozoic carbonate platforms of the Tethyan realm. Facies $52: 435-440$

Conrad MA, Clavel B (2008) A Lithocodium and Bacinella signature of a late Hauterivian, local microbial event: the Urgonian limestone in south-east France. Geol Croatica 61:239-250

Conrad MA, Varol B (1990) Cylindroporella taurica, n. sp., urges to review different patterns of calcification in the Mesozoic Dasycladales (Green Algae). Arch Sci Genève 43:193-214

Correa J (1994) Infections by pigmented algal endophytes: misuse of concepts and terminology. Rev Chilena Hist Nat 67:4-8

Correa J, Nielsen R, Grund DW, MacLachlan J (1987) Endophytic algae of Irish moss (Chondrus crispus Stackh.). Hydrobiologia 151(152):223-228

Correa JA, Nielsen R, Grund DW (1988) Endophytic algae of Chondrus crispus (Rhodophyta). II. Acrochaete heteroclada sp. nov., A. operculata sp. nov., and Phaeophila dendroides (Chlorophyta). J Phycol 24:528-539

Daoud H, Bucur II, Săsăran E, Cociuba I (2004) Lower Cretaceous limestones from the northern part of Padurea Craiului (Osoiu Hill and Subpiatra Sections): biostratigraphy and preliminary data on microbial structures. Studia Univ Babes-Bolyai Geol 49:49-62

De Castro P (1990) Thaumatoporelle: conoscenze attuali e approcio all'interpretazione. Boll Soc Paleont Ital 29:176-206

De Castro P (1997) Introduzione allo studio in sezione sottile delle dasicladali fossili. Quad Accad Pontaniana 22:1-137

De Castro P (2002) Thaumatoporella parvovesiculifera (Raineri): typification, age and historical background (Senonian, Sorrento Peninsula-southern Italy). Boll Soc Paleont Ital 41:121-129

Dragastan O, Richter DK (2003) Calcareous algae and foraminifers from Neocomian limestones of Methana Peninsula, Asprovouni Mts. (Greece) and from south Dobrogea (Romania). Analele Univ Bucuresti Geol Spec Pub 1:57-128

Dragastan O, Golubić S, Richter DK (1996) Rivularia haematites: a case of the recent versus fossil morphology. Taxonomical considerations. Rev Esp Micropal 28:43-73

Dupraz C, Strasser A (1999) Microbialites and micro-encrusters in shallow coral bioherms (Middle to Late Oxfordian, Swiss Jura Mountains). Facies 40:101-130 
Dupraz C, Strasser A (2002) Nutritional modes in coral-microbialite reefs (Jurassic, Oxfordian, Switzerland): evolution of trophic structure as a response to environmental change. Palaios 17:449-471

Elliott GF (1956) Further records of fossil calcareous algae from the Middle East. Micropaleontology 2:327-334

Elliott GF (1963) Problematical microfossils from the Cretaceous and Paleocene of the Middle East. Palaeontology 6:293-300

Elliott GF (1978) Ecologic significance of post-Palaeozoic green calcareous algae. Geol Mag 115:437-442

Endo R (1961) Calcareous algae from the Jurassic of Torinosu Limestone. Sci Rep Saitama Univ B Comm Vol: 53-75

Erbacher J, Thurow J, Littke R (1996) Evolution pattern of Radiolaria and organic matter variations: a new approach to identify sea-level changes in mid-Cretaceous pelagic environments. Geology 24:499-502

Fagerstrom AG (1987) The evolution of reef communities. Wiley, New York, p 600

Fan KC (1959) Studies on the life histories of marine algae. I. Codiolum petrocelidis and Spongomorpha coalita. Bull Torrey Bot Soc 86:1-12

Fenninger A (1972) Die Fauna und Flora der Barmsteinkalk-Bank B2 im Raume des Trattberges (Osterhorngruppe, Salzburg). Ber Haus Nat Salzburg 3:10-23

Flügel E (2004) Microfacies of carbonate rocks-analysis, interpretation and application. Springer, Berlin Heidelberg New York, $976 \mathrm{pp}$

Försterra G, Beuck L, Häussermann V, Freiwald A (2005) Shallowwater Desmophyllum dianthus (Scleractinia) from Chile: characteristics of the biocoenoses, the bioeroding community, bathymetric implications. In: Freiwald A, Roberts JM (eds) Cold-water corals and ecosystems. Springer, Berlin Heidelberg New York, pp 937-977

Foster JS, Green SJ, Ahrendt SR, Golubić S, Reid RP, Hetherington KL, Bebout L (2009) Molecular and morphological characterization of cyanobacterial diversity in the stromatolites of Highborne Cay, Bahamas. ISME J 2009:1-15

Gall JG (2001) 3.2.4. Role of microbial mats. In: Briggs D, Crowther PR (eds) Palaeobiology II. Blackwell, Oxford, pp 280-284

Gautier F (1980) Villarluengo, hoja n ${ }^{\circ} 543$. Mapa Geológico de España 1:50.000. $2^{\text {a }}$ Serie. $1^{\mathrm{a}}$ Edición. Servicio de Publicaciones, Ministerio de Industria y Energía, Madrid $45 \mathrm{pp}$

Gektidis M, Dubinsky Z, Goffredo S (2006) Microendoliths of the shallow euphotic zone in open and shaded habitats at $30^{\circ} \mathrm{N}$-Eilat, Israel-paleoecological implications. Facies 53:43-55

Ghirardelli LA (2002) Endolithic microorganisms in live and dead thalli of coralline red algae (Corallinales, Rhodophyta) in the Northern Adriatic Sea. Acta Geol Hisp 37:53-60

Glaub I (1994) Mikrobohrspuren in ausgewählten Ablagerungsräumen des europäischen Jura und der Unterkreide (Klassifikation und Palökologie). Courier Forschungsinst Senckenberg 174:1-324

Glaub I, Vogel K (2004) The stratigraphic record of microborings. Foss Strata 51:126-135

Glaub I, Golubić S, Gektidis M, Radtke G, Vogel K (2007) Microborings and microbial endoliths: geological implications. In: Miller J (ed) Trace fossils. Springer, Berlin Heidelberg New York, pp 368-381

Golubić S (1983) Kunstharzausgüsse fossiler Mikroben-Bohrgänge. Der Präparator 29:197-200

Golubić S, Radtke G (2008) The trace Rhopalia clavigera isp. n. reflects the development of its maker Eugomontia sacculata Kornmann 1960. In: Wisshak M, Tapanila L (eds) Current developments in bioerosion. Springer, Berlin Heidelberg New York, pp 95-108

Golubić S, Perkins RS, Lucas KJ (1975) Boring microorganisms and microborings in carbonate substrates. In: Frey RW (ed) The study of trace fossils. Springer, Berlin Heidelberg New York, pp 229259

Golubić S, Friedmann I, Schneider J (1981) The lithobiontic ecological niche, with special reference to microorganisms. J Sediment Petrol 51:475-478

Götz S, Löser H, Schmid DU (2005) Reef development on a deepening platform: two Early Cretaceous coralgal patch reefs (Catí, Llàcova Formation, eastern Spain) compared. Cret Res 26:864-881

Granier B (2003) Cretaceous calcareous algae and microbial carbonates from Prebetic Zone (Betic Cordillera, E Spain). In: Braga JC, Aguirre J (eds) 8th International symposium on fossil algae, field trip guide book. Publ Univ Granada, pp 25-34

Grötsch J, Koch R, Buser S (1994) Fazies, Gildenstruktur und Diagenese des nördlichen Randes der Dinarischen Karbonatplattform (Barreme-Apt, W-Slowenien). Abh geol Bundesanstalt 50:125153

Guiry MD, Guiry GM (2009) AlgaeBase. World-wide electronic publication, National University of Ireland, Galway. http://www. algaebase.org

Günther A (1990) Distribution and bathymmetric zonation of shellboring endoliths in recent reef and shelf environments: Cozumel, Yucatan (Mexico). Facies 22:233-262

Heindel K, Wisshak M, Westphal H (2008) Microbioerosion in Tahitian reefs: a record of environmental change during the last deglacial sea-level rise (IODP 319). Lethaia 42:322-340

Helm C (2005) Riffe und fazielle Entwicklung der florigemma-Bank (Korallenoolith, Oxfordium) im Süntel und östlichen Wesergebirge (NW-Deutschland). Geol Beitr Hannover 7:3-339

Hillgärtner H, Dupraz C, Hug W (2001) Microbially induced cementation of carbonate sands: are micritic meniscus cements good indicators for vadose diagenesis? Sedimentology 48:117-131

Höfling R (1985) Faziesverteilung und Fossilvergesellschaftungen im karbonatischen Flachwasser-Milieu der alpinen Oberkreide (Gosau-Formation). Münchner Geowiss Abh 3:1-206

Holmes KE, Edinger EN, Limmon HG, Risk MJ (2000) Bioerosion of massive corals and branching coral rubble on Indonesian coral reefs. Mar Poll Bull 40:606-617

Hyde KD, Zhang Y (2008) Epitypification: should we epitypify? J Zhejiang Univ Sci B 9:842-846

Immenhauser A, Hillgärtner H, Van Bentum E (2005) Microbial-foraminiferal episodes in the Early Aptian of the southern Tethyan margin: ecological significance and possible relation to oceanic anoxic event 1a. Sedimentology 52:77-99

Immenhauser A, Huck S, Rameil N, Heimhofer U, Korbar T, Wieczorek TD, Kunkel C (2009) Tethys-wide occurrence of Lower Aptian Lithocodium-Bacinella facies: shoalwater expression of basinal OAE1a black shales. Geochim Cosmochim Acta 73 (Goldschmidt Conference Abstracts):A568

Jansa LF, Termier G, Termier H (1982) Les biohermes à algues, spongiaires et coraux des série carbonatées de la flexure bordière du « paleoshelf » au large du Canada oriental. Rev Micropaléontol 25:181-219

Johnson HJ (1964) The Jurassic algae. Q Colorado School Min 59:1129

Johnson HJ (1969) A review of the Lower Cretaceous algae. Prof Contr Colorado School Mines 6:1-180

Kazmierczak J, Kempe S (2006) Genuine modern analogues of Precambrian stromatolites from caldera lakes of Niuafo' ou Island, Tonga. Naturwiss 93:119-126

Keupp H, Jenisch A, Herrmann R, Neuweiler F, Reitner J (1993) Microbial carbonate crusts-a key to the environmental analysis of fossil spongolites? Facies 29:41-54

Kiene W, Radtke G, Gektidis M, Golubić S, Vogel K (1995) Factors controlling the distribution of microborers in Bahamian reef environments. In: Schuhmacher H, Kiene W, Dullo WC (coord) 
Factors controlling Holocene reef growth: an interdisciplinary approach. Facies 32:176-184

Kitayama T, Garrigue C (1998) Marine algal endophytes new to New Caledonia. Bull Nat Sci Mus Tokyo ser B 24:93-101

Kobluk DR, Risk M (1977) Calcification of exposed filaments of endolithic algae, micrite envelope formation and sediment production. J Sediment Petrol 47:517-528

Koch R, Moussavian E, Ogorelec B, Skaberne D, Bucur II (2002) Development of a Lithocodium (syn. Bacinella irregularis)-reefmound-A patch reef within Middle Albian lagoonal limestone sequence near Nova Gorica (Sabotin Mountain, W-Slovenia). Geologija 45:71-90

Kolodziej B, Golubić S, Radtke G, Bucur II (2008) Fossil record of microendoliths in living coral skeletons. In: Uchman A (ed) The second international congress on ichnology, 28.07-28.09.2008, Kraków, Abstract Book and the Intra-Congress Field Trip Guidebook, p 64

Kolodziej B (1997) Boring foraminifera from exotics of the Stramberk-type limestones (Tithonian-Lower Berriasian, Polish Carpathians). Ann Soc Geol Pol 67:249-256

Kornmann P (1959) Die heterogene Gattung Gomontia I. Der sporangiale Anteil, Codiolum polyrhizum. Helgol Mar Res 6:229-238

Kornmann P (1960) Die heterogene Gattung Gomontia II. Der fädige Anteil, Eugomontia sacculata nov. gen. nov. spec. Helgol Mar Res 7:59-71

Kornmann P (1961) Über Codiolum und Urospora. Helgol Mar Res $8: 42-57$

Kornmann P (1962) Die Entwicklung von Monostroma grevillei. Helgol Mar Res 8:195-202

Kornmann P (1970) Der Lebenszyklus von Acrosiphonia grandis (Acrosiphoniales, Chlorophyta). Mar Biol 7:324-331

Kuss J (1983) Faziesentwicklung in proximalen Intraplattform-Becken: Sedimentation, Palökologie und Geochemie der Kössener Schichten (Ober-Trias, Nördliche Kalkalpen). Facies 9:61-172

Le Campion-Alsumard T (1979) Les Cyanophycées endolithes marines. Systématique, ultrastructure, écologie et biodestruction. Ocean Acta 2:143-156

Le Campion-Alsumard T, Golubić S, Hutchings P (1995) Microbial endoliths in skeletons of live and dead corals: Porites lobata (Moorea, French Polynesia). Mar Ecol Press Ser 117:149-157

Leinfelder RR (1985) Cyanophyte calcification morphotypes and depositional environments (Alenquer Oncolite, Upper Kimmeridgian? Portugal). Facies 12:253-274

Leinfelder RR (1986) Facies, stratigraphy and paleogeographic analysis of Upper? Kimmeridgian to Upper Portlandian sediments in the environs of Arruda dos Vinhos, Estremadura, Portugal. Münchner Geowiss Abh A 7:1-216

Leinfelder RR (2001) Jurassic reef ecosystems. In: Stanley GD Jr (ed) The history and sedimentology of ancient reef systems. Kluwer, Plenum, New York, pp 251-309

Leinfelder RR, Nose M, Schmid DU, Werner W (1993) Microbial crusts of the Late Jurassic: composition, palaeoecological significance and importance in reef construction. Facies 29:195-230

Leinfelder RR, Schlagintweit F, Werner W, Ebli O, Nose M, Schmid DU, Hughes GW (2005) Significance of stromatoporoids in Jurassic reefs and carbonate platforms. Concepts and implications. Facies 51:287-325

Lukas K (1974) Two species of the chlorophyte genus Ostreobium from skeletons of Atlantic and Caribbean reef corals. J Phycol 10:331-335

Luperto Sinni E (1979) I microfossili del "livello a Palorbitolina lenticularis" delle Murge Baresi. Riv Ital Paleont 85:411-480

Macintyre IG, Prufert-Bebout L, Reid RP (2000) The role of endolithic cyanobacteria in the formation of lithified laminae in Bahamian stromatolites. Sedimentology 47:915-921
Magnusson SH, Fine M, Kühl M (2007) Light microclimate of endolithic phototrophs in the scleractinian corals Montipora monasteriata and Porites cylindrica. Mar Ecol Prog Ser 332:119-128

Masse JP (1979) Schizophytoides du Crétacé Inférieur caractéristiques et signification écologique. Bull Cent Rech Explor Prod Elf Aquitaine 3:685-703

Massieux M, Denizot M (1964) Rapprochement du genre Pseudolithothamnium Pfender avec le genre actuel Ethelia Weber Van Bosse (Algues Florideae, Squamariaceae). Rev Micropaleontol 7:31-42

Matyszkiewicz J, Slomka T (2004) Reef-microencrusters association Lithocodium aggregatum-Bacinella irregularis from the Cieszyn Limestone (Tithonian-Berriasian) of the outer Western Carpathians (Poland). Geol Carpathica 55:449-456

Maurin AF, Bernet-Rollande MC, Monty CLV, Nazhat S (1985) The microbial nature of bacinellid textures. Sedimentological bearings. In: 9th European regional meeting of sedimentology, Leiden, abstracts, pp 285-287

McNeill J, Barrie FR, Burdet HM, Demoulin V, Hawksworth DL, Marhold K, Nicolson DH, Prado J, Silva PC, Skog JE et al. (2006) International code of botanical nomenclature (Vienna Code). Available from http://ibot.sav.sk/icbn/main.htm (Accessed Aug. 2008)

Merz MUE, Zankl H (1993) The influence of culture conditions on growth and sheath development of calcifying Cyanobacteria. Facies 29:75-80

Mišík M (1979) Jurassic and Cretaceous algae (Dasycladales excepted) from the West Carpathians. Bull Centres Rech Explor Prod Elf Aquitaine 3:705-712

Moreno-Bedmar JA, Company M, Bover-Arnal T, Salas R, Delanoy G, Martínez R, Grauges A (2009) Biostratigraphic characterization by means of ammonoids of the lower Aptian Oceanic Anoxic Event (OAE1a) in the eastern Iberian Chain (Maestrat Basin, eastern Spain). Cretaceous Res 30:864-872

Moreno-Bedmar JA, Company M, Bover-Arnal T, Salas R, Maurrasse FJ, Delanoy G, Grauges A, Martínez R (2010) Lower Aptian ammonite biostratigraphy in the Maestrat Basin (eastern Iberian chain, Spain). Geologica Acta (in press)

Mu X (1991) Fossil Udoteaceae and Gymnocodiaceae. In: Riding R (ed) Calcareous algae and stromatolites. Springer, Berlin Heidelberg New York, pp 146-166

Neuweiler F, Reitner J (1992) Karbonatbänke mit Lithocodium aggregatum Elliott/Bacinella irregularis Radoičić. Paläobathymetrie, Paläoökologie und stratigraphisches Äquivalent $\mathrm{zu}$ thrombolithischen Mud Mounds. Berliner Geowiss Abh 3:273-293

Nielsen R (1987) Marine algae within calcareous shells from New Zealand. N Z J Bot 25:425-438

Noffke N (2008) Turbulent lifestyle: microbial mats on earth's sandy beaches-today and 3 billion years ago. GSA Today 18. doi: 10.1130/GSATG7A.1

O'Kelly CJ, Wysor B, Bellows WK (2004) Collinsiella (Ulvophyceae, Chlorophyta) and other Ulotrichalean taxa with shell-boring sporophytes form a monophyletic clade. Phycologia 43:41-49

Pantazidou A, Louvrou I, Economou-Amilli A (2006) Euendolithic shell-boring cyanobacteria and chlorophytes from the saline lagoon Ahivadolimni on Milos, Island, Greece. Eur J Phycol 41:189-200

Perry CT (1998) Grain susceptibility to the effects of microboring: implications for the preservation of skeletal carbonates. Sedimentology 45:39-51

Perry CT, Macdonald IA (2002) Impacts of light penetration on the bathymetry of reef microboring communities: implications for the development of microendolithic trace assemblages. Palaeogeogr Palaeoclimat Palaeoecol 186:101-113

Poignant AF (1968) Les algues des calcaires aptiens et albiens de 1'Aquitaine méridionale. Rev Micropaleontol 10:271-276 
Pratt BR (1995) The origin, biota and evolution of deep-water mudmounds. In: Monty CLV, Bosence D, Bridges PH, Pratt BR (eds) Carbonate mud-mounds, their origin and evolution. Int Assoc Sediment Spec Publ 23:49-123

Pröschold T, Leliaert F (2007) Systematics of the green algae: Conflict of classic and modern approaches In: Brodie J, Lewis JM (eds) Unravelling the algae: the past, present, and future of algal systematics. Taylor and Francis, pp 123-153

Radoičić R (1959) Nekoliko problematicnih mikrofosila iz dinarske krede (some problematic microfossils from the Dinarian Cretaceous). Vesnik 17:87-92

Radoičić R (2005) New Dasycladales and microbiota from the lowermost Valanginian of the Mirdita Zone. Ann Géol Pénins Balk 66(2004-2005):27-53

Radtke G (1991) Die mikroendolithischen Spurenfossilien im AltTertiär West-Europas und ihre palökologische Bedeutung. Cour Forsch-Inst Senckenberg 138:1-185

Radtke G, Golubić S (2005) Microborings in mollusk shells, Bay of Safaga, Egypt: Morphometry and ichnology. Facies 51:118-134

Raineri R (1922) Alghe sifonee fossili della Libia. Nota I. Atti Soc Ital Sc Nat Museo Civico 61:72-86

Rameil N, Immenhauser A, Warrlich G, Hillgärtner H, Droste HJ (2010) Morphological patterns of Aptian Lithocodium-Bacinella geobodies-relation to environment and scale. Sedimentology. doi: 10.1111/j.1365-3091.2009.01124.x

Raven JA (2002) The evolution of cyanobacterial symbioses. Proc R Irish Acad 102B:3-6

Reid P, Macintyre IG (2000) Microboring versus recrystallization: further insight into the micritization process forming micritized grains. J Sediment Res 70:24-28

Reitner J (1987) Mikrofazielle, palökologische und paläogeographische Analyse ausgewählter Vorkommen flachmariner Karbonate im Basko-kantabrischen Strike Slip Fault-Becken-System (Nordspanien) an der Wende von der Unterkreide zur Oberkreide. Documenta Nat 40:1-239

Riding R (1977) Calcified Plectonema (blue-green algae), a recent example of Girvanella from Aldabra Atoll. Palaeontology 20:3346

Riding R (1991a) Calcified cyanobacteria. In: Riding R (ed) Calcareous algae and stromatolites. Springer, Berlin Heidelberg New York, pp 55-87

Riding R (1991b) Classification of microbial carbonates. In: Riding R (ed) Calcareous algae and stromatolites. Springer, Berlin Heidelberg New York, pp 21-51

Riding R (2000) Microbial carbonates: the geological record of calcified bacterial-algal mats and biofilms. Sedimentology 47(supplement 1):179-214

Riding R (2006) Cyanobacterial calcification, carbon dioxide concentrating mechanisms, and Proterozoic-Cambrian changes in atmospheric composition. Geobiology 4:299-316

Rose CS, Risk MJ (1985) Increase in Cliona delitrix infestation on Montastrea cavernosa heads on an organically polluted portion of the Grand Cayman fringing reef. Mar Ecol 6:345-363

Round FE (1981) The ecology of algae. Cambridge University Press, Cambridge, p 664

Salas R, Guimerà J, Martín-Closas C, Meléndez A, Alonso A (2001) Evolution of the Mesozoic Central Iberian Rift System and its Cainozoic inversion (Iberian Chain). In: Ziegler PA, Cavazza W, Roberston AHF, Crasquin-Soleau S (eds) Peri-Tethys Memoir 6: Peri-Tethyan Rift/Wrench Basins and Passive Margins. Mém Mus Nat Hist Nat Paris 186:145-186

Săsăran E, Bucur II, Prica I (2001) Microfacies and microfossils in Upper Jurassic limestones from the Cheile Turenilor. Studia Univ Babeş-Bolyai Geol 46:35-52

Schäfer P, Senowbari-Daryan B (1983) Die Kalkalgen aus der Obertrias von Hydra, Griechenland. Palaeontographica 185:83-142
Schlagintweit F (1991) Allochthone Urgonkalke im Mittleren Abschnitt der Nördlichen Kalkalpen: Fazies, Paläontologie und Paläogeographie. Münchner Geowiss Abh 20:1-120

Schlagintweit F (2008) Bioerosional structures and pseudoborings from Late Jurassic and Late Cretaceous-Paleocene shallow-water carbonates (Northern Calcareous Alps, Austria; SE France) with special reference to cryptobiotic foraminifera. Facies 54:377-402

Schlagintweit F, Ebli O (1999) New results on microfacies, biostratigraphy and sedimentology of Late Jurassic-Early Cretaceous platform carbonates of the Northern Calcareous Alps. Part I: Tressenstein limestone, Plassen-formation. Abh Geol BA 56:379-418

Schlagintweit F, Gawlick HJ, Lein R (2005) Mikropaläontologie und Biostratigraphie der Plassen-Karbonatplattform der Typlokalität (Ober-Jura bis Unter-Kreide, Salzkammergut, Österreich). J Alpine Geol (Mitt Ges Geol Bergbaustud Österr) 47:11-102

Schmid DU (1996) Marine Mikrobolithe und Mikroinkrustierer aus dem Oberjura. Profil 9:101-251

Schmid DU, Leinfelder RR (1996) The Jurassic Lithocodium aggregatum-Troglotella incrustans foraminiferal consortium. Palaeontology 39:21-52

Schmidt H (1992) Mikrobohrspuren ausgewählter Faziesbereiche der tethyalen und germanischen Trias (Beschreibung, Vergleich und bathymetrische Interpretation). Frankfurter Geowiss Arb 12:1228

Scholz H (1979) Paläontologie, Aufbau und Verbreitung der Bioherme und Biostrome im Allgäuer Schrattenkalk (Helvetikum, Unterkreide). Unpublished PHD thesis TU Munich, 133 pp

Schott M (1983) Sedimentation und Diagenese einer absinkenden Karbonatplattform: Rhät und Lias des Brünnstein-Auerbach-Gebietes, Bayerische Kalkalpen. Facies 9:1-60

Schroeder JH (1972) Calcified filaments of an endolithic alga in recent Bermuda reefs. N J Geol Paläont Mh 16-33

Schroeder R (1975) General evolutionary trends in orbitolinas. Rev Esp Micropaleontol Numero Especial 1987:117-128

Scoffin TP, Bradshaw C (2000) The taphonomic significance of endoliths in dead-versus live-coral skeletons. Palaios 15:248-254

Segonzac G, Marin P (1972) Lithocodium aggregatum Elliott et Bacinella irregularis Radoičić de l'Aptien de Teruel (Espagne): deux stades de croissance d'un seul et meme organisme incertae sedis. Bull Soc géol France (Série 7) 14:331-335

Senowbari-Daryan B (1980) Fazielle und paläontologische Untersuchungen in oberrhätischen Riffen (Feichtenstein- und Gruberriff bei Hintersee, Salzburg, Nördliche Kalkalpen). Facies 3:1-237

Senowbari-Daryan B (1984) Mikroproblematika aus den obertriadischen Riffkalken von Sizilien. Münstersche Forsch Geol Paläontol 61:1-81

Senowbari-Daryan B, Bucur II, Abate B (1994) Upper Jurassic calcareous algae from the Madonie Mountains, Sicily. Beitr Paläont 19:227-259

Setchell WA, Gardner NL (1903) Algae of northwestern America. Univ California Pub Bot 1:165-418

Setchell WA, Gardner NL (1920) The marine algae of the Pacific Coast of north America. Part II Chlorophyceae. Univ California Pub Bot 8:139-374

Shen JW, Qing H (2008) Calcimicrobes, microbial fabrics, and algae in Mississippian Midale Beds, Midale and Glen Ewen Pools, Williston Basin, southeastern Saskatchewan. Summary of investigation, Saskatchewan. Geol Surv Misc Rep 2008-4.1:1-10

Shen JW, Webb GE (2008) The role of microbes in reef-building communities of the Cannindah limestone (Mississippian), Monto region, Queensland, Australia. Facies 54:89-105

Smith SV, Kimmerer WJ, Laws EA, Brock RE, Walsh TW (1981) Kaneohe Bay sewerage diversion experiment. Perspectives on ecosystem responses to nutritional perturbations. Pac Sci 35:279395 
Srinivasan KS (1962) Report on Phaeophila dendroides (Crouan) Batters endophytic in Rosenvingea intricata (J. Ag.) Boergs. Bull Bot Survey India 3:111-113

Stal LJ (2007) Cyanobacteria: diversity and versatility, clues to life in extreme environments. In: Seckbach J (ed) Algae and Cyanobacteria in extreme environments. Springer, Berlin Heidelberg New York, pp 659-680

Stanton RJ, Flügel E (1989) Problems with reef models: The Late Triassic Steinplatte "reef" (Northern Alps, Salzburg/Tyrol, Austria). Facies 20:1-138

Steuber T (2001) Strontium isotope stratigraphy of Turonian-Campanian Gosau-type rudist formations in the Northern Calcareous Alps (Austria and Germany). Cretaceous Res 22:429-441

Sumner DY (1997) Late Archean calcite-microbe interactions: two morphologically distinct microbial communities that affected calcite nucleation differently. Palaios 12:302-318

Sussmann AV, DeWreede RE (2001) Life history of Acrosiphonia (Codiolales, Chlorophyta) in southwestern British Columbia, Canada. Am J Bot 88:1535-1544

Tapanila L, Cooper P, Edinger E (2004) Environmental and substrate control on Paleozoic bioerosion in corals and stromatoporoids, Anticosti Island, Eastern Canada. Palaios 19:292-306

Thivy F (1943) New records of some marine Chaetophoraceae and Chaetosphaeridiaceae for North America. Biol Bull 85:244-264

Tribollet A (2007) The boring microflora in modern coral reef ecosystems: a review of its roles. In: Wisshak M, Tapanila L (eds) Current developments in bioerosion. Springer, Berlin Heidelberg New York, pp 67-94

Tribollet A (2008) Dissolution of dead corals by euendolithic microorganisms across the northern Great Barrier Reef (Australia). Microbial Ecol 55:569-580

Tribollet A, Payri C (2001) Bioerosion of the coralline alga Hydrolithon onkodes by microborers in the coral reefs of Moorea, French Polynesia. Oceanol Acta 24:329-342
Tucker ME, Wright VP (1990) Carbonate sedimentology. Blackwell, Oxford, $\mathrm{p} 482$

Turnsek D, Buser S (1966) The development of the Lower Cretaceous beds and the boundary between Jurassic and Cretaceous formations in the western part of Trnovski Gozd. Geologija 9:543-548

Vachard D, Hauser M, Martini R, Zaninetti L, Matter A, Peters T (2001) New algae and problematica of algal affinity from the Permian of the Aseelah Unit of the Batain Plain (East Oman). Géobios 34:375-404

Védrine S, Strasser A, Hug W (2007) Oncoid growth and distribution controlled by sea-level fluctuations and climate (Late Oxfordian, Swiss Jura Mountains). Facies 53:535-552

Waite LW, Scott RW, Kerans C (2007) Middle Albian age of the regional dense marker bed of the Edwards Group, Pawnee Field, South-Central Texas. Gulf Coast Assoc Geol Sci Transact 57:759-774

Wilkinson M, Burrows EM (1972) An experimental taxonomic study of the algae confused under the name Gomontia polyrhiza. J Mar Biol Ass UK 52:49-57

Wisshak M (2006) High-latitude bioerosion-the Kosterfjord experiment. Lecture Notes Earth Sci 109:1-202

Wisshak M, Seuß B, Nützel A (2008) Evolutionary implications of an exceptionally preserved Carboniferous microboring assemblage in the Buckhorn Asphalt lagerstätte (Oklahoma, USA). In: Wisshak M, Tapanila L (eds) Current developments in bioerosion. Springer, Berlin Heidelberg New York, pp 21-54

Wood R (1999) Reef evolution. Oxford University Press, Oxford, p 414

Wurm D (1982) Mikrofazies, Paläontologie und Palökologie der Dachsteinriffkalke (Nor) des Gosaukammes, Österreich. Facies 6:203-296

Ziegler MA (2001) Late Permian to Holocene paleofacies evolution of the Arabian plate and its hydrocarbon occurrences. GeoArabia $6(3): 445-503$ 